National and Global Petroleum Resources Assessment Project

\title{
Geologic Assessment of Undiscovered Oil and Gas Resources in the Cherokee Platform Province Area of Kansas, Oklahoma, and Missouri
}

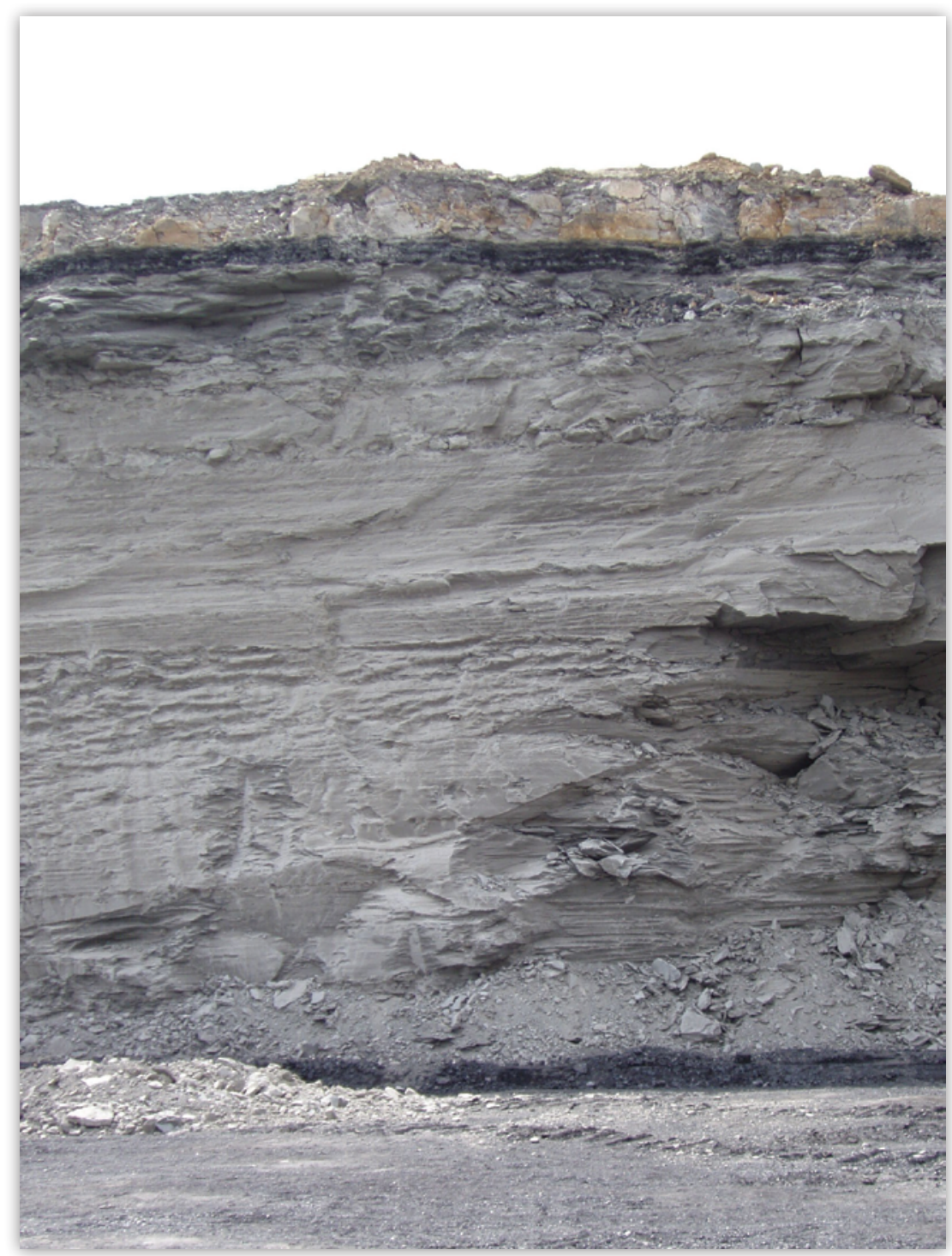

Scientific Investigations Report 2020-5110 
Cover photographs. Front cover. Desmoinesian Coal beds in the Upper Senora Formation at the Phoenix Kelly Ranch Coal Mine in Craig County, Okla. (Photograph by Brian Cardott)

Back cover. Cushing Field in Creek County, Okla., in 1915 compared to 2011. (Both photographs from the U.S. Geological Survey Denver Library Photographic Collection, Fath A.E. Collection [U.S. public domain]. Panorama created by Stanley Paxton, U.S. Geological Survey) 


\section{Geologic Assessment of Undiscovered Oil and Gas Resources in the Cherokee Platform Province Area of Kansas, Oklahoma, and Missouri}

By Ronald M. Drake II and Joseph R. Hatch

National and Global Petroleum Resources Assessment Project

Scientific Investigations Report 2020-5110 


\section{U.S. Geological Survey, Reston, Virginia: 2021}

For more information on the USGS — the Federal source for science about the Earth, its natural and living resources, natural hazards, and the environment-visit https://www.usgs.gov or call 1-888-ASK-USGS.

For an overview of USGS information products, including maps, imagery, and publications, visit https://store.usgs.gov.

Any use of trade, firm, or product names is for descriptive purposes only and does not imply endorsement by the U.S. Government.

Although this information product, for the most part, is in the public domain, it also may contain copyrighted materials as noted in the text. Permission to reproduce copyrighted items must be secured from the copyright owner. https://usgs.gov/copyright.

Suggested citation:

Drake, R.M., II, and Hatch, J.R., 2021, Geologic assessment of undiscovered oil and gas resources in the Cherokee Platform area of Kansas, Oklahoma, and Missouri: U.S. Geological Survey Scientific Investigations Report 2020-5110, 39 p., https://doi.org/10.3133/sir20205110.

ISSN 2328-031X (print)

ISSN 2328-0328 (online)

ISBN 978-1-4113-4399-3 


\section{Contents}

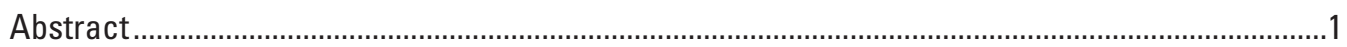

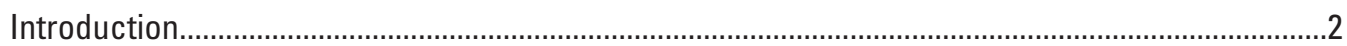

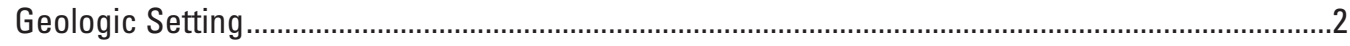

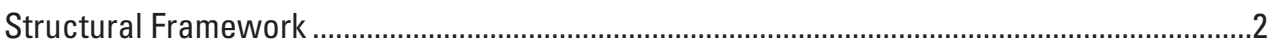

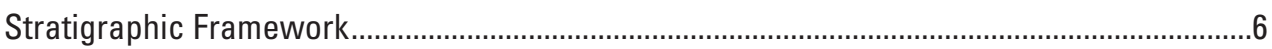

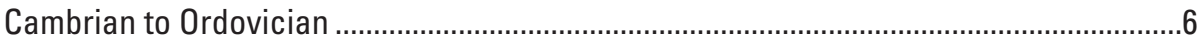

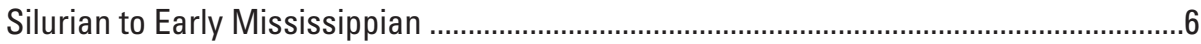

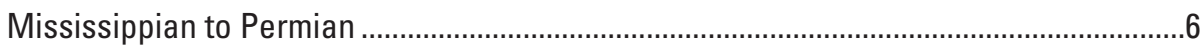

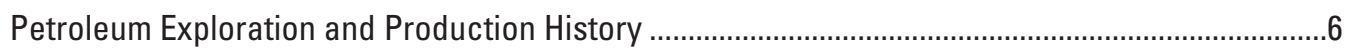

Petroleum Assessment Terminology and Methodology...........................................................

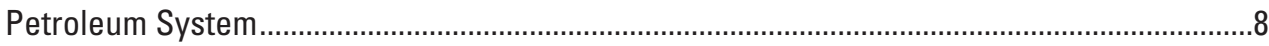

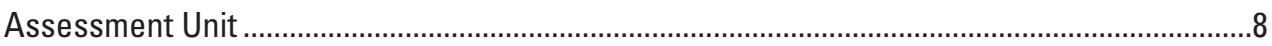

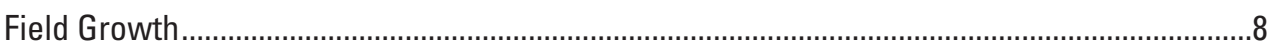

Economic Truncation ........................................................................................................

Petroleum Source Rock Characterization ..............................................................................

Petroleum Systems of the Cherokee Platform Province ..............................................................10

Paleozoic Composite Total Petroleum System.........................................................................10

Middle Ordovician Simpson Group ................................................................................. 10

Petroleum Source Rock Characterization ...................................................................10

Organic Matter Contents ..................................................................................13

Organic Matter Hydrogen Richness .......................................................................13

Organic Matter Thermal Maturity ...............................................................................13

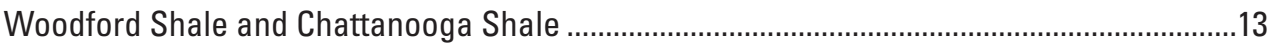

Petroleum Source Rock Characterization ..................................................................

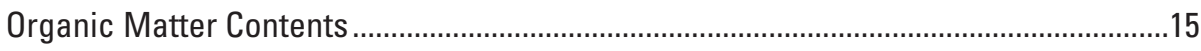

Organic Matter Hydrogen Richness ..........................................................................16

Organic Matter Thermal Maturity ...............................................................................

Middle and Upper Pennsylvanian Marine Shales.............................................................18

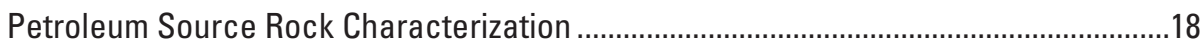

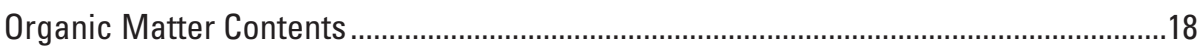

Organic Matter Hydrogen Richness .........................................................................19

Organic Matter Thermal Maturity .............................................................................19

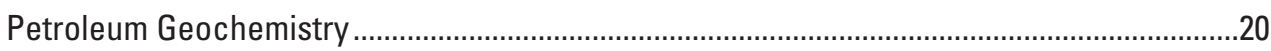

Oils

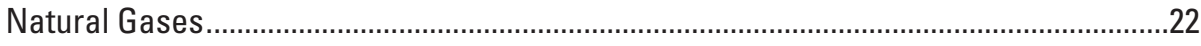

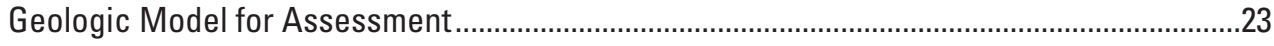

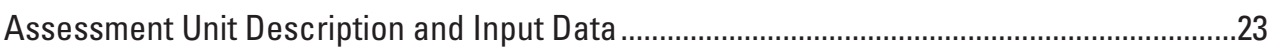

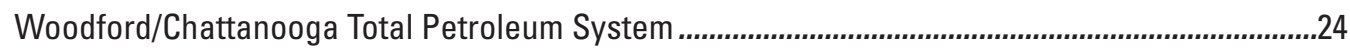

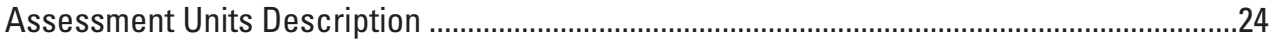

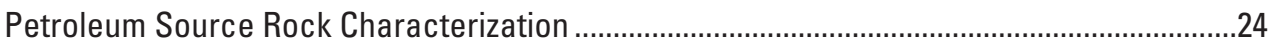

Geologic Model for Assessment and Input Data ..................................................................2

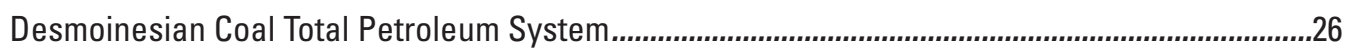

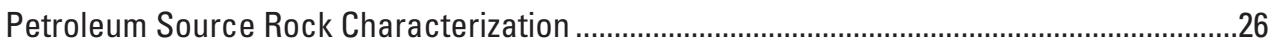




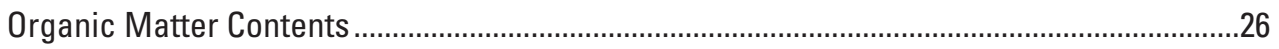

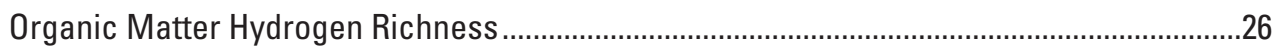

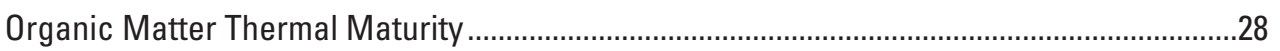

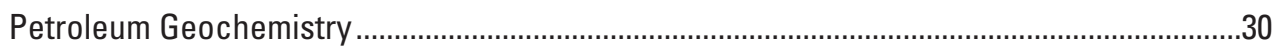

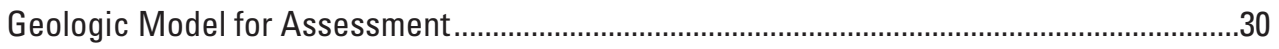

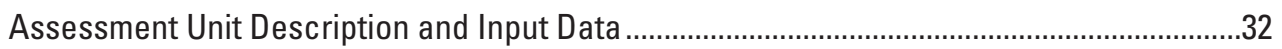

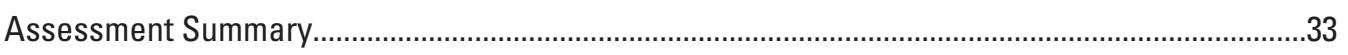

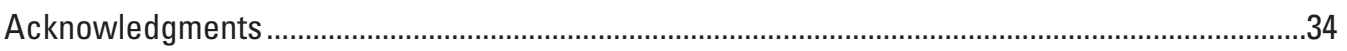

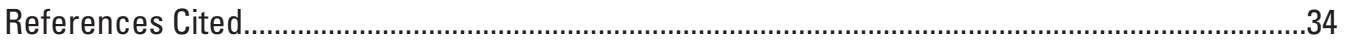

\section{Figures}

1. Map showing locations of the Cherokee Platform Province and regional structural features of the midcontinent.............................................................................................

2. Stratigraphic chart for the Cherokee Platform Province area.............................................

3. West-east cross section through the Cherokee Basin showing major stratigraphic units and generalized structure

4. Map of oil and gas production wells in the Cherokee Platform Province area....

5. Schematic diagram illustrating conventional and unconventional oil and gas accumulations as used in assessments by the U.S. Geological Survey.

6. Map of the spatial distribution of the Paleozoic Conventional Assessment Unit (AU), the Woodford Shale Oil AU, the Woodford Biogenic Gas AU, and the Desmoinesian Coalbed Gas AU in the Cherokee Platform Province of southeastern Kansas, western Missouri, and northeastern Oklahoma..

7. Map of the extent and lithofacies of the Simpson Group..

8. Histogram showing the distribution of organic-carbon contents (weight percent) for 17 shale samples from the Middle Ordovician Simpson Group from eastern Kansas and 5 samples from northwestern Missouri.

9. Histogram showing the distribution of hydrogen indices for 17 samples from the Middle Ordovician Simpson Group from eastern Kansas and 5 samples from northwestern Missouri

10. Isopach map of Upper Devonian strata in Oklahoma, Arkansas, and Kansas.................14

11. Generalized map showing the distribution of organic carbon contents for the Woodford Shale in Oklahoma

12. Histogram showing the distributions of the average organic carbon contents for samples from 4 cores of the Woodford and Chattanooga Shales from eastern Kansas and from 14 cores from central and south-central Oklahoma...

13. Histogram showing the distributions of the average Rock-Eval hydrogen indices for samples from 4 cores of the Woodford and Chattanooga Shales from eastern Kansas and from 14 cores from central and south-central Oklahoma...

14. Vitrinite reflectance map of the Woodford Shale

15. Cross plot showing the relation between the average hydrogen index and average $\mathrm{R}_{0}$ for 18 sets of Woodford Shale core samples that are primarily from central and south-central Oklahoma and 19 sets of Woodford Shale outcrop samples that are primarily from eastern and southeastern Oklahoma and from northwestern Arkansas 
16. Histogram showing the distribution of organic carbon contents for 47 shale samples from the Desmoinesian Marmaton Group (8 samples) and the Missourian Kansas City Group (39 samples) from southeastern Kansas and northeastern Oklahoma

17. Histogram showing the distribution of hydrogen indices for 47 shale samples from the Desmoinesian Marmaton Group (8 samples) and the Missourian Kansas City Group (39 samples) from southeastern Kansas and northeastern Oklahoma

18. Cross plot showing the relation between hydrogen index and Tmax for 16 shale samples from the Desmoinesian Marmaton Group and 39 samples from the Missourian Kansas City Group from southeastern Kansas and northeastern Oklahoma

19. Saturated hydrocarbon fraction gas chromatogram for an oil collected from the Livengood (also known as Livingood) field, Brown County, Kansas.

20. Saturated hydrocarbon fraction gas chromatogram for an oil collected from the Paola-Rantoul field, Miami County, Kansas. Production is from the Squirrel sand of the Middle Pennsylvanian Marmaton Group...

21. Saturated hydrocarbon fraction gas chromatogram for an oil collected from the field, Wabaunsee County, Kansas. Production for this well is from a reservoir in the Upper Pennsylvanian Kansas City Group

22. Histogram showing the distribution of net thicknesses of Cherokee Group coals in wells from the area of the Desmoinesian Coalbed Gas Assessment Unit in southeastern Kansas and northeastern Oklahoma

23. Stratigraphic chart of the Desmoinesian Cherokee and Marmaton Groups in the Cherokee Platform area of southeastern Kansas and northeastern Oklahoma.

24. Histogram showing the distribution of organic-carbon contents for $40 \mathrm{coal}$ and 48 coal-associated shale and mudstone samples from the Desmoinesian Cherokee Group and Marmaton Group of southwestern Missouri, southeastern Kansas, and northeastern Oklahoma

25. Histogram showing the distribution of hydrogen indices for $40 \mathrm{coal}$ and 48 coal-associated shale and mudstone samples from the Middle Pennsylvanian (Desmoinesian) of southeastern Kansas and northeastern Oklahoma.

26. Histogram showing the distribution of Tmax measures for $27 \mathrm{coal}$ samples from southeastern Kansas and southwestern Missouri and 29 coal samples from northeastern Oklahoma

27. Cross plot showing the relation between hydrogen index and Tmax degree Celsius for 27 coal samples from southeastern Kansas and southwestern Missouri and 29 coal samples from northeastern Oklahoma.

28. Cross plot showing the relation between hydrogen index and Tmax degree Celsius for 27 Middle Pennsylvanian shale and mudstone samples from southeastern Kansas and southwestern Missouri and 45 shale and mudstone samples from northeastern Oklahoma

29. Plot of gas wetness compared with methane $\delta^{13} \mathrm{C}$.

30. Map of the Desmoinesian Coalbed Gas Assessment Unit (AU) and the Desmoinesian Coalbed Gas sweet spot 


\section{Tables}

1. Statistical summary of the chemical compositions of nine natural gas samples collected from wells producing from Middle and Upper Ordovician, Silurian, and Lower Devonian (Hunton Group) reservoirs on the Cherokee Platform area of northeastern Oklahoma

2. Statistical summary of the chemical compositions of 88 natural gas samples collected from wells producing from Mississippian and Pennsylvanian (Morrowan, Atokan, and Desmoinesian) reservoirs on the Cherokee Platform area of northeastern Oklahoma

3. Statistical summary of the chemical compositions of eight natural gas samples collected from wells producing from Upper Pennsylvanian reservoirs on the Cherokee Platform area of southeastern Kansas and northeastern Oklahoma

4. Statistical summary of the chemical compositions of 13 natural gas samples collected from wells producing from Mississippian, Morrowan, Atokan, and Desmoinesian reservoirs on the Cherokee Platform area of southeastern Kansas .......23

5. Key assessment input data for the Paleozoic Conventional Assessment Unit in the Cherokee Platform Province.

6. Assessment results for petroleum resources in the Paleozoic Conventional Assessment Unit in the Cherokee Platform Province area ..

7. Key assessment input data for the Woodford Shale Oil Assessment Unit and the Woodford Biogenic Gas Assessment Unit in the Cherokee Platform Province.

8. Assessment results for the petroleum resources of the Woodford Shale Oil Assessment Unit and the Woodford Biogenic Gas Assessment Unit in the Cherokee Platform Province area.

9. Key assessment input data for the Desmoinesian Coalbed Gas Assessment Unit in the Cherokee Platform Province.....

10. Assessment results for petroleum resources in the Desmoinesian Coalbed Gas Assessment Unit in the Cherokee Platform Province area

11. Assessment results for conventional and continuous petroleum resources in the Cherokee Platform Province area 


\section{Conversion Factors}

Inch/Pound to International System of Units (SI)

\begin{tabular}{lcl}
\hline & Multiply & \multicolumn{1}{c}{ To obtain } \\
\hline inch (in.) & Length & \\
inch (in.) & 2.54 & centimeter $(\mathrm{cm})$ \\
foot (ft) & 25.4 & millimeter $(\mathrm{mm})$ \\
mile (mi) & 0.3048 & meter $(\mathrm{m})$ \\
\hline & 1.609 & kilometer $(\mathrm{km})$ \\
\hline Acre & Area & \\
Acre & 4,047 & square meter $\left(\mathrm{m}^{2}\right)$ \\
Acre & 0.4047 & hectare $($ ha $)$ \\
Acre & 0.4047 & square hectometer $\left(\mathrm{hm}^{2}\right)$ \\
square inch $\left(\mathrm{in}^{2}\right)$ & 0.004047 & square kilometer $\left(\mathrm{km}^{2}\right)$ \\
square mile $\left(\mathrm{mi}^{2}\right)$ & 6.452 & square centimeter $\left(\mathrm{cm}^{2}\right)$ \\
square mile $\left(\mathrm{mi}^{2}\right)$ & 259.0 & hectare $($ ha $)$ \\
\hline & 2.590 & square kilometer $\left(\mathrm{km}^{2}\right)$ \\
\hline barrel (bbl), $\left(\mathrm{petroleum}^{2} 1 \mathrm{barrel}=42 \mathrm{gal}\right)$ & Volume & \\
cubic foot $\left(\mathrm{ft}^{3}\right)$ & 0.1590 & cubic meter $\left(\mathrm{m}^{3}\right)$ \\
\hline Celsius $(\mathrm{C})$ & 0.02832 & cubic meter $\left(\mathrm{m}^{3}\right)$ \\
\hline
\end{tabular}

\section{Abbreviations}

AU Assessment Unit

TPS Total Petroleum System 



\title{
Geologic Assessment of Undiscovered Oil and Gas Resources in the Cherokee Platform Province Area of Kansas, Oklahoma, and Missouri
}

\author{
By Ronald M. Drake II and Joseph R. Hatch
}

\section{Abstract}

In 2015, the U.S. Geological Survey completed a geology-based assessment to estimate the volumes of undiscovered, technically recoverable petroleum resources in the Cherokee Platform Province area of southeastern Kansas, northeastern Oklahoma, and southwestern Missouri. The U.S. Geological Survey identified four stratigraphic intervals that contain petroleum source rocks: (1) thin shales in the Middle to Upper Ordovician Simpson Group, (2) shales within the Upper Devonian to Lower Mississippian Woodford Shale and stratigraphically equivalent Chattanooga Shale, (3) coals and coal-associated shales and mudstones in the Middle Pennsylvanian (Desmoinesian) Cherokee and Marmaton Groups, and (4) thin marine shales within the Marmaton Group and the Upper Pennsylvanian (Missourian) Kansas City and Lansing Groups. Based on the nature of the petroleum accumulations, the characterization of the compositions and thermal maturity of the organic matter in the rocks, and the compositions of the produced petroleum, the U.S. Geological Survey identified three total petroleum systems (TPS) containing four assessment units (AU): the Paleozoic Composite TPS with the Paleozoic Conventional Assessment Unit (AU), the Woodford/Chattanooga TPS with the Woodford Shale Oil AU and the Woodford Biogenic Gas AU, and the Desmoinesian Coal TPS with the Desmoinesian Coalbed Gas AU. Assessment unit summaries follow

1. Three source rock intervals have contributed geochemically distinct oils to reservoirs within the Paleozoic Conventional AU. These intervals are the Simpson Group; the Woodford and Chattanooga Shales; and the Marmaton, Kansas City, and Lansing Groups. The major petroleum source rocks are the Woodford and Chattanooga Shales. The Paleozoic Conventional $\mathrm{AU}$ includes reservoirs that range in age from the Upper Cambrian Arbuckle Group to the lower Permian Chase Group. Most oil production in the province has been from Pennsylvanian sandstone reservoirs. Estimated undiscovered petroleum resources for this $\mathrm{AU}$ are a mean of 3 million barrels of oil (MMBO), 140 billion cubic feet of gas (BCFG), and 4 million barrels of natural gas liquids (MMBNGL).
2. The Woodford Shale Oil AU contains undiscovered continuous petroleum resources within the Woodford Shale and Chattanooga Shale. The geologic model for the $\mathrm{AU}$ assumes that petroleum resources remain trapped within the shale following petroleum migration. For most of the AU, organic matter within the Woodford Shale and Chattanooga Shale is thermally mature with respect to petroleum generation as shown by vitrinite reflectance values between 0.6 and 1 percent. Petroleum has been produced from the Woodford Shale and Chattanooga Shale. Estimated undiscovered petroleum resources for this $\mathrm{AU}$ are means of $460 \mathrm{MMBO}$, 640 BCFG, and 7 MMBNGL.

3. The Woodford Shale Biogenic Gas AU contains undiscovered continuous petroleum resources in the east-central portion of the Cherokee Platform Province near the Ozark uplift where the Woodford Shale and Chattanooga Shale are at depths of $1,250 \mathrm{ft}$ or shallower. At those depths, methanogenesis and(or) biodegradation of thermogenic natural gases can be found where the shale may be more fractured and more susceptible to groundwater penetrations. The mean assessed volume of undiscovered gas for this assessment unit is $416 \mathrm{BCFG}$ and 1 MMBNGL.

4. The Desmoinesian Coalbed Gas AU contains undiscovered continuous petroleum resources within the Middle Pennsylvanian coals and coal-associated shales and mudstones. The boundaries for the Desmoinesian Coalbed Gas AU are, in part, defined by the extent, depth, and thickness of the coals. Within the Desmoinesian Coalbed Gas AU, a sweet spot area was delineated based on a 10 foot or greater net coal thickness. Gas analytical data show that natural gas produced from the coals has a mixed biogenic and thermogenic origin and that there is significant migration of natural gas into the coals from adjacent conventional sandstone reservoirs. The estimated mean volume of undiscovered gas is 10.0 trillion cubic $\mathrm{ft}$ of gas (TCFG), and 23 MMBNGL. 
For the three continuous (unconventional) assessment units and one conventional assessment unit in the Cherokee Platform Province, total mean volumes of undiscovered petroleum resources are estimated to be $463 \mathrm{MMBO}$, 11.2 TCFG and 35 MMBNGL.

\section{Introduction}

In 2015, the U.S. Geological Survey (USGS) conducted an assessment to estimate the volumes of undiscovered, technically recoverable petroleum resources in the Cherokee Platform Province area of southeastern Kansas, northeastern Oklahoma, and southwestern Missouri. For this assessment the USGS identified four stratigraphic/lithologic intervals that contained petroleum source rocks: (1) thin shale intervals in the Middle Ordovician Simpson Group, (2) shales within the Upper Devonian to Lower Mississippian Woodford Shale and stratigraphically equivalent Chattanooga Shale, (3) coals and coal-associated shales and mudstones in the Middle Pennsylvanian (Desmoinesian) Cherokee and Marmaton Groups, and (4) thin marine shales within the Marmaton Group and the Upper Pennsylvanian (Missourian) Kansas City and Lansing Groups. Based on the nature of the petroleum accumulations, the characterization of the compositions and thermal maturity of the organic matter in the rocks, and the compositions of the produced petroleum, the USGS identified three total petroleum systems (TPSs) containing four assessment units (AUs): (1) the Paleozoic Composite TPS with the Paleozoic Conventional AU, (2) the Woodford/ Chattanooga TPS with the Woodford Shale Oil AU and the Woodford Biogenic Gas AU, and (3) the Desmoinesian Coal TPS with the Desmoinesian Coalbed Gas AU.

This publication describes the geologic setting of the Cherokee Platform Province, the petroleum exploration and production history, and the petroleum assessment terminology and methodologies that were used for this assessment. This information is followed by descriptions of the three TPSs and four AUs identified in the basin, along with supporting geological data and maps that were used in the assessment. The USGS methodology for predicting undiscovered volumes of hydrocarbons (Charpentier and Cook, 2011; Charpentier and Klett, 2005) was used to quantitatively assess the petroleum resources.

\section{Geologic Setting}

The Cherokee Platform is located on the east side of the Nemaha uplift and is bounded on the north by the Bourbon arch, on the east by the Ozark uplift, on the south by the Arkoma Basin, and on the southwest by Arbuckle uplift and the Anadarko Basin (fig. 1).

\section{Structural Framework}

The Cherokee Platform formed as a relatively stable platform in southeastern Kansas and northeastern Oklahoma updip from the Anadarko and Arkoma Basins in southern Oklahoma and southwestern Arkansas (Merriam, 1999). Tectonic activity in the Cherokee Platform area has been relatively minor. Most of the major tectonic events occurred adjacent to the Cherokee Platform in the Anadarko and Arkoma Basins to the south and southwest (fig. 1). During the Cambrian, there was a failed rift system called the Southern Oklahoma aulacogen in what is now the Anadarko Basin. This failed rift arm filled with large amounts of igneous rocks that were intruded (gabbros and granites) and extruded (basalts and rhyolites) along the axis of the aulacogen (Perry, 1989). Following the filling of the aulacogen axis, the rocks subsided, which formed the Oklahoma trough. This trough was filled with more than 11,000 feet (ft) of mostly Cambrian to Lower Devonian carbonates (Perry, 1989) during development of the Anadarko Basin.

The Late Silurian to Early Devonian marked the formation of the central Kansas uplift and the central Kansas and Chautauqua arches to the northwest of the Cherokee Platform (fig. 1). The central Kansas uplift and the central Kansas arch are northwest-trending structures on the western side of the Chautauqua arch. These structural features restricted the deposition of the Hunton Group (fig. 2) in the Cherokee Platform area to northeastern Kansas (Merriam, 1963; Blakey, 2013). During the Early Pennsylvanian (Morrowan and early Atokan), the South American plate and North American plate collided, which led to the Ouachita and Wichita orogenies (Amarillo-Wichita uplift) (fig. 1). The Ouachita and Wichita orogenic pulses may have begun as early as the Mississippian and ended in the Middle Pennsylvanian (Desmoinesian) (Johnson, 2008). These pulses included significant northward thrusting. According to Johnson (2008), there were 10,000 to $15,000 \mathrm{ft}$ of uplift in the Wichita Mountains. The Nemaha and Ozark uplifts also developed during this time; the Nemaha uplift was active in the Late Mississippian to Early Pennsylvanian and was reactivated during the Mesozoic (Dolton and Finn, 1988).

Uplift during the Early Pennsylvanian caused the erosion of most pre-Pennsylvanian (Chester Group; fig. 2) rocks from the paleotopographic highs on the Wichita Mountains, Criner Hills, and the central Oklahoma arch creating an unconformity between the Mississippian and Early Pennsylvanian (Morrow Group) strata (fig. 2). Subsidence during the early Middle Pennsylvanian (Atokan) is associated with sediment accumulation of 10,000 ft in the Anadarko Basin (Rascoe and Adler, 1983). On the Cherokee Platform is commonly 2,000 to $5,000 \mathrm{ft}$ of Pennsylvanian strata (Johnson, 2008) (fig. 3). 


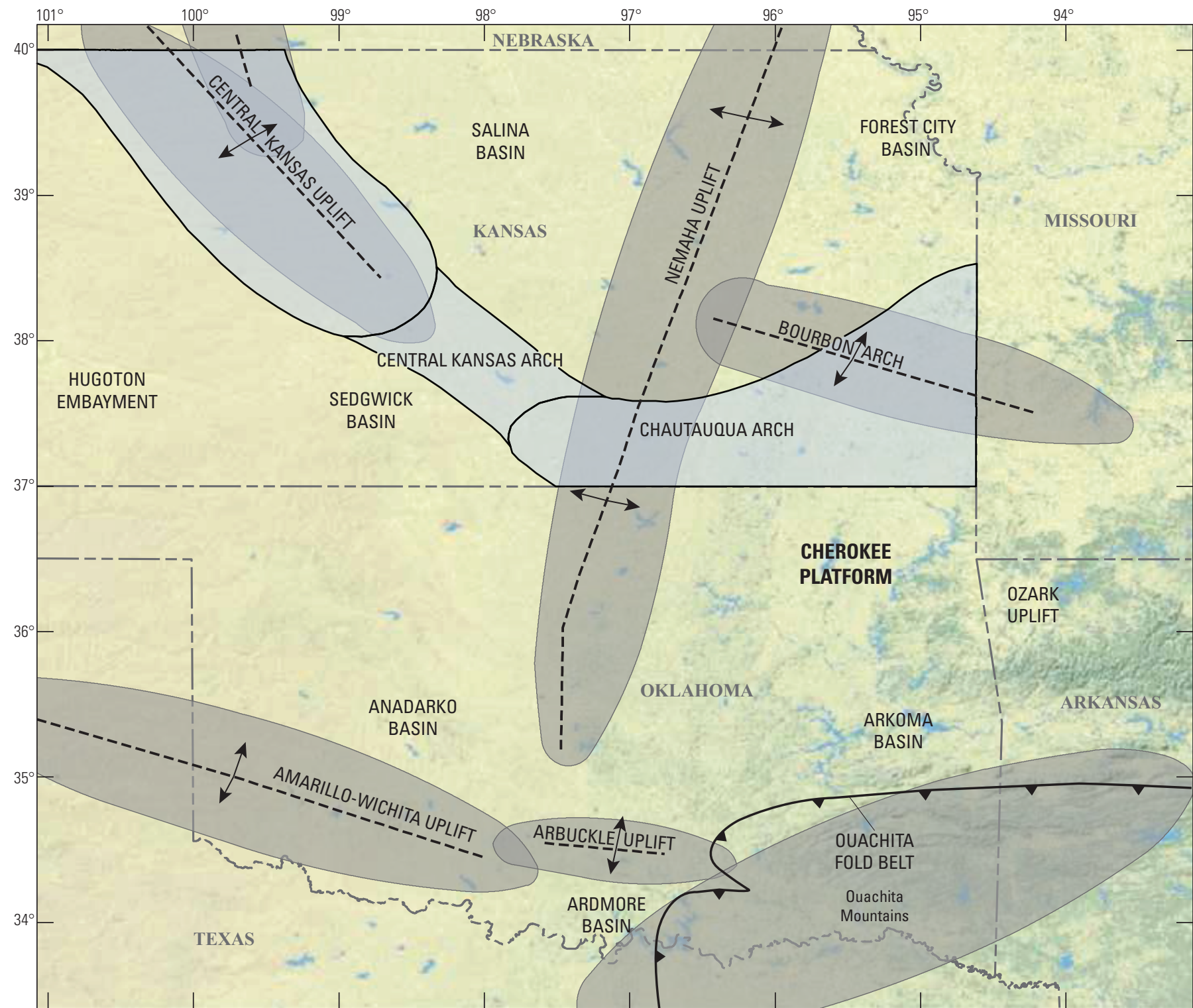

Base from U.S. National Park Service digital data, March 1, 2015 Geographic coordinate system, decimal degrees World Geodetic System 1984 datum

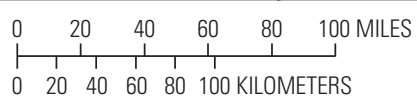

EXPLANATION

Mississippian or Post-Mississippian

Pre-Mississippian

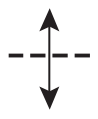

Anticline-Arrows pointing downdip away from the fold axis. Location approximate

_ـ Thrust fault-Sawteeth indicate upthrown side

Figure 1. Locations of the Cherokee Platform Province and regional structural features of the midcontinent. 


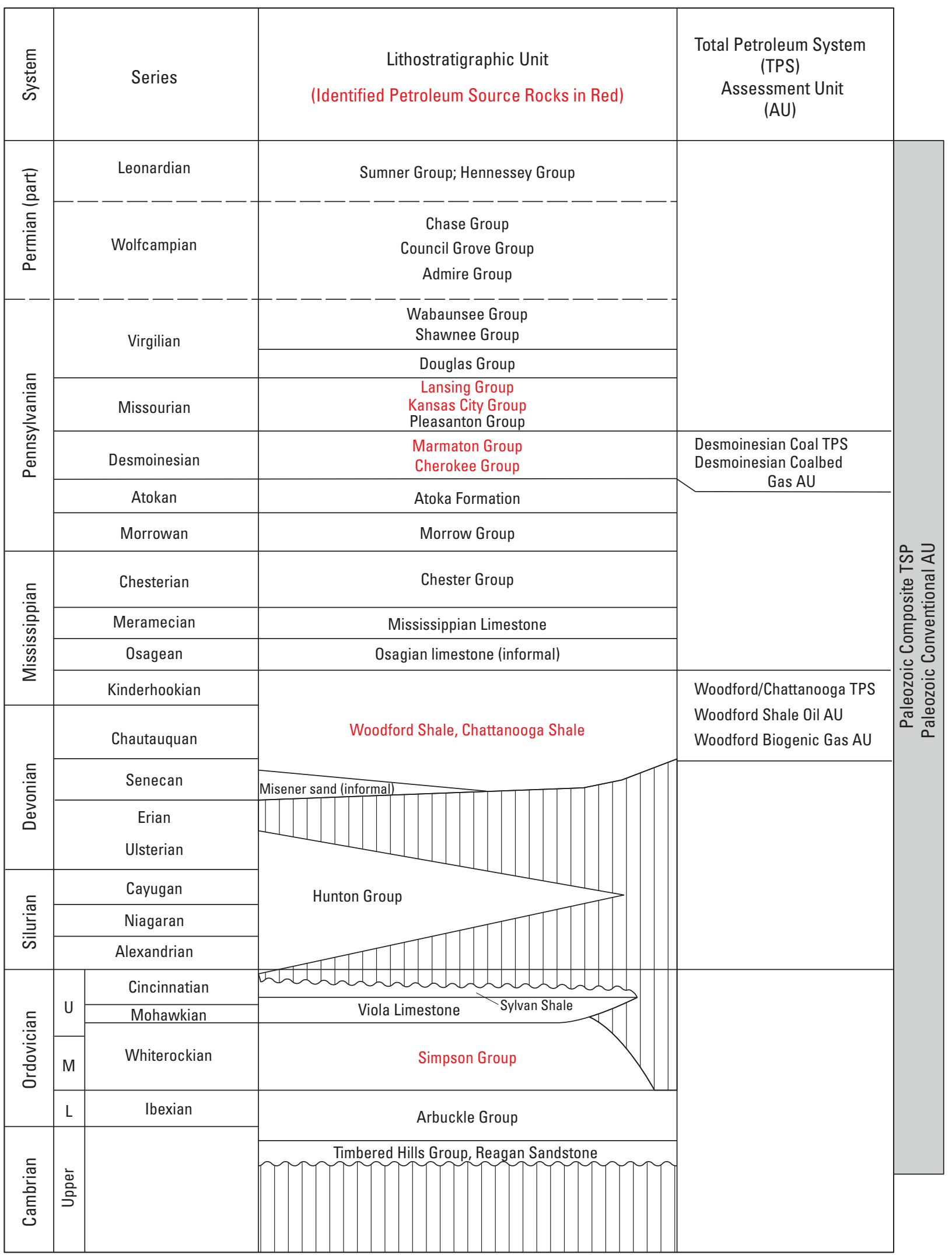

Figure 2. Cherokee Platform Province area (modified from Gaswirth and Higley, 2014). Stratigraphic boundaries for the three Total Petroleum Systems and four Assessment Units and intervals with petroleum source rocks are shown. 

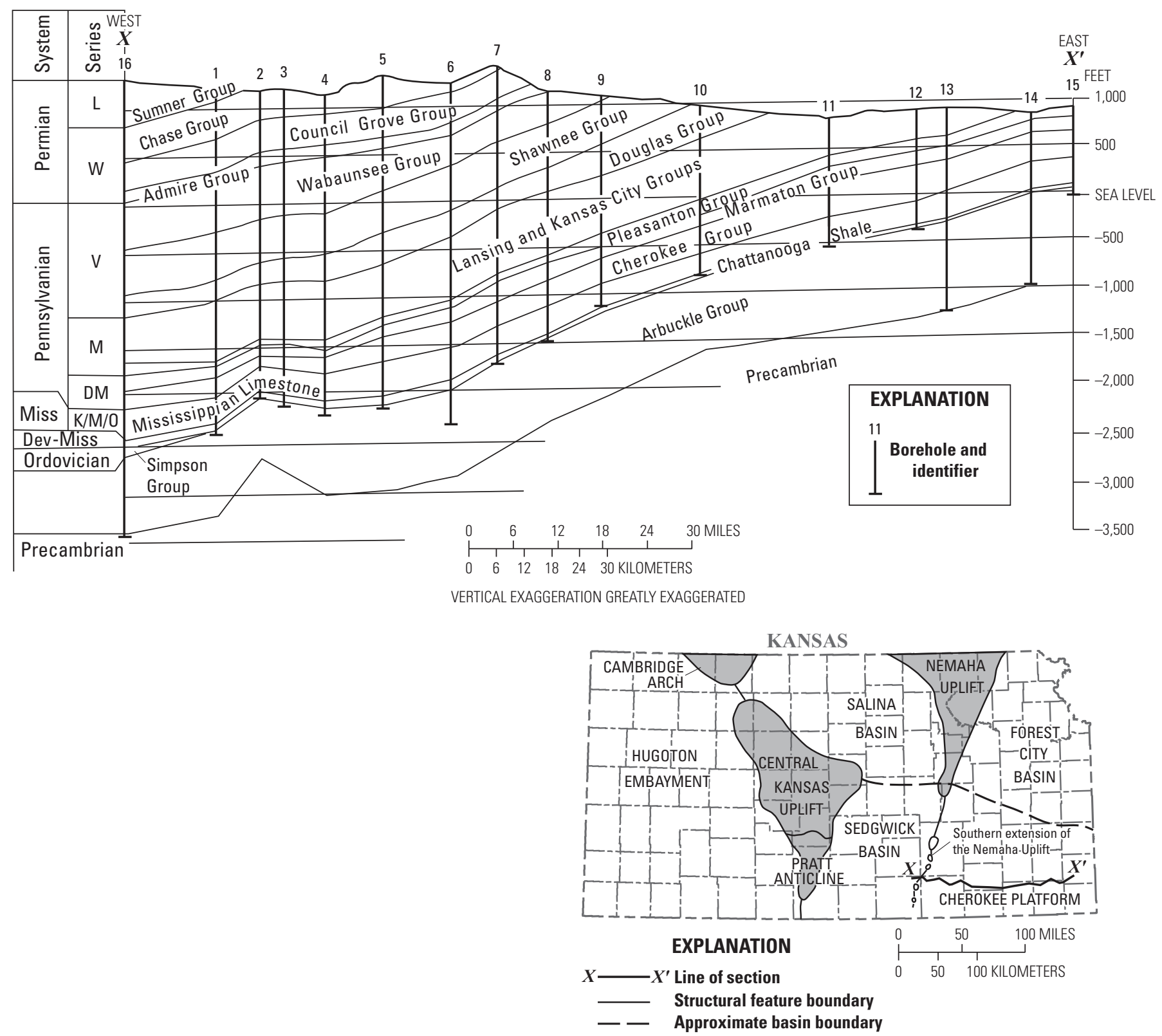

Figure 3. West-east cross section through the Cherokee Basin showing major stratigraphic units and generalized structure (adapted from Merriam, 1963). L, Leonardian; W, Wolfcampian; V, Virgilian; M, Missourian; DM, Desmoinesian; K, Kinderhookian; M, Meramecian; 0, Osagian; Miss., Mississippian; Dev., Devonian (modified from Förster and others, 1998). 


\section{Stratigraphic Framework}

\section{Cambrian to Ordovician}

Basement rocks that underlie the sedimentary rocks of the Cherokee Platform are composed of Proterozoic igneous and metamorphic rocks that formed about 1.4 billion years ago (Johnson, 2008). The oldest sedimentary rocks in the area are Late Cambrian to Early Ordovician in age (fig. 2). During the Late Cambrian, the area was covered by a shallow sea and sand from eroded basement rocks was deposited as the Reagan Sandstone. This was followed by the deposition of thick limestones and dolomites of the Arbuckle Group. In the Cherokee Platform area, the Arbuckle Group is 1,000 to $2,000 \mathrm{ft}$ thick and thickens to about 7,000 ft to the south into the Anadarko and Ardmore Basins (Ham, 1973; Johnson, 2008). Overlying the Arbuckle Group carbonates are shallow marine shales, limestones, and sandstones of the Simpson Group, Viola Limestone, and Sylvan Shale. The thickness of the middle to upper parts of the Simpson Group increases from about $100 \mathrm{ft}$ in the northeast part of the Cherokee Platform to about $800 \mathrm{ft}$ in Pottawatomie County, Oklahoma, in the southwest part of the platform area (Suhm, 1997). Thick widespread limestones and dolomites of the Viola Limestone overlie the Simpson Group, and the top of the Viola Limestone exhibits karst topography. The Sylvan Shale overlies the Viola Limestone and it may act as a hydrocarbon seal.

\section{Silurian to Early Mississippian}

The Silurian to Devonian Hunton Group limestones on the Cherokee Platform are usually $100-500 \mathrm{ft}$ thick. These Hunton Group rocks were later eroded from the northern platform area as the Chautauqua arch was uplifted in the Late Silurian to Early Devonian. Hunton Group strata are present in the northwest corner of the Cherokee Platform and in the southern portion of the area. The Upper Devonian to Lower Mississippian Woodford Shale unconformably overlies the Hunton Group in the southern portion of the Cherokee Platform. In eastern Kansas and the northeastern portion of Oklahoma, the stratigraphically equivalent Chattanooga Shale overlies the Misener Sandstone (Kuykendall and Fritz, 2001). In the Oklahoma portion of the Cherokee Platform, the Misener Sandstone has been described as a time transgressive deposit of fine-grained quartz sand with some dolomite, which was deposited on the postHunton Group unconformity and within associated fluvial channels (Gaswirth and Higley, 2014). Although the Misener Sandstone is not widespread, it has been a prolific oilproducing unit. The Woodford Shale and the stratigraphically equivalent Chattanooga Shale were deposited in a deep, low-energy, dysoxic to anoxic marine environment. In the Cherokee Platform area, these shales are typically about $50 \mathrm{ft}$ thick, but can be as much as $200 \mathrm{ft}$ thick in the southern portion of the area.

\section{Mississippian to Permian}

During the Mississippian, thick deposits of limestone, dolomite, and chert developed in a shallow sea on the continental shelf. Rock types in the Middle and Upper Pennsylvanian in the midcontinent area have long been recognized as recording intervals of cyclical sedimentation (cyclothems) (Weller, 1930; Moore, 1931, 1936; Wanless and Weller, 1932). Each cyclothem records a single transgressiveregressive sequence with rock types representing deposition in both marine and nonmarine environments (marine and terrestrial sandstones and shales, marine carbonates, and coal). During the Permian, shallow marine limestones were deposited along with gray and red shales and red sandstones (nonfossiliferous, red clastic deposits).

\section{Petroleum Exploration and Production History}

The first well in the area was completed in 1873 in the Iola field in Allen County, Kansas (Moore and Elledge, 1920; Nehring Associates, Inc., 2014), where oil and gas were produced from sandstone of the Cherokee Group. Most of the conventional fields in the area have produced oil and gas from Pennsylvanian-aged sandstones (figs. 2 and 23). More than 3.4 billion barrels of oil and more than 3.8 trillion cubic $\mathrm{ft}$ of gas have been produced from more than 48 thousand wells (IHS Markit $\left.{ }^{\mathrm{TM}}, 2014\right)$. The distribution of wells with oil and gas production in the Cherokee Platform Province area is shown in figure 4 . Only about 2 percent of the producing wells are directional or horizontal wells.

Recent petroleum industry interest in the area has shifted to producing gas from the Desmoinesian coals. More than 6,500 coalbed gas wells are in the area and earliest production started in 1979 in coals of the Cherokee Group in Rogers County, Oklahoma, (IHS Markit ${ }^{\mathrm{TM}}$, 2014). Nearly 500 billion cubic feet of natural gas (BCFG) produced, primarily from the coals in the Cherokee Group (IHS Markit ${ }^{\mathrm{TM}}, 2014$ ). Of the nearly 700 producing Woodford Shale and Chattanooga Shale wells in the area, almost 500 are horizontal or directional wells; more than 59 BCFG and more than 12 million barrels of oil (MMBO) have been produced from these wells (IHS Markit ${ }^{\mathrm{TM}}$, 2017). 


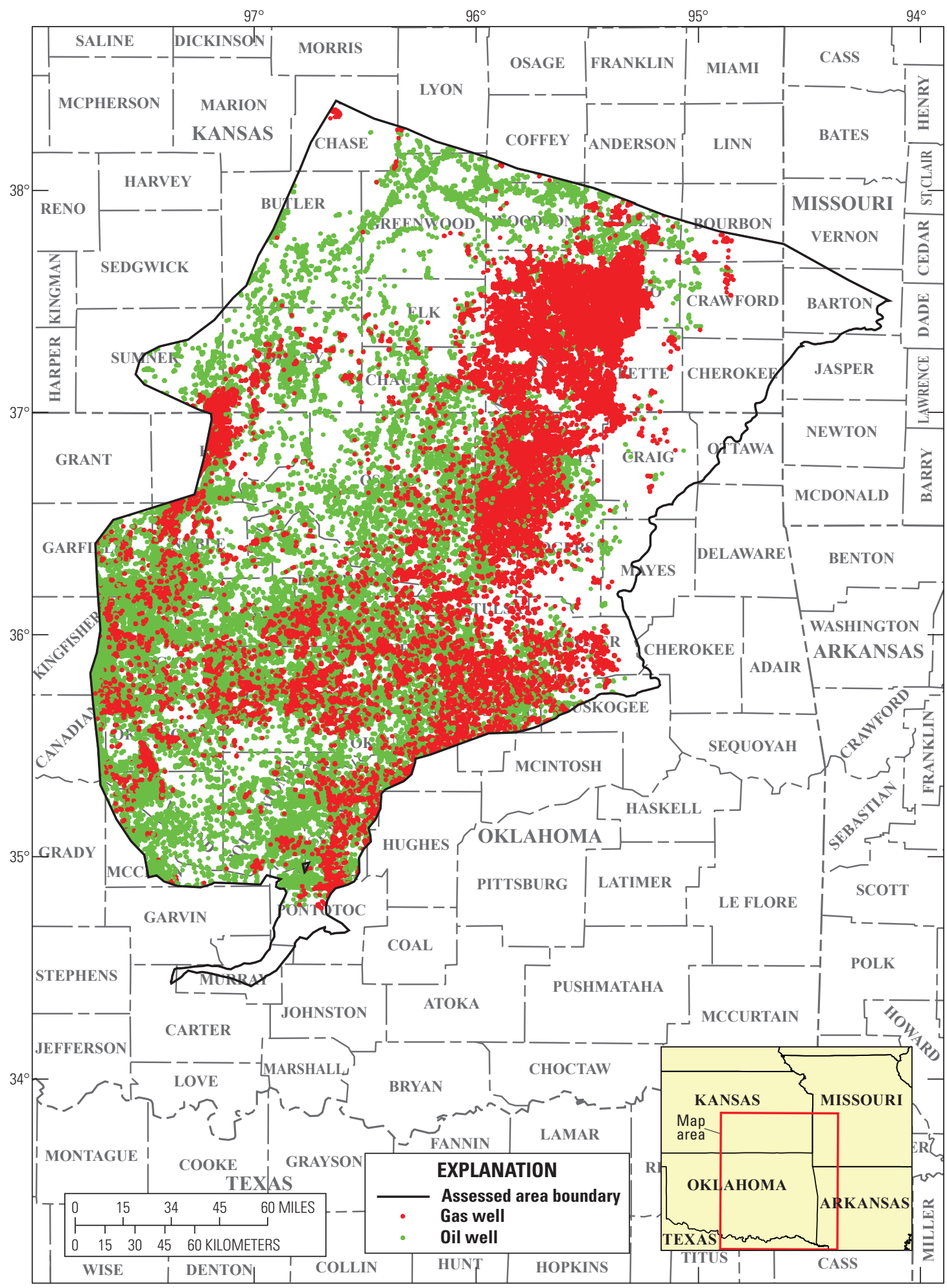

Base from U.S. National Park Service digital data, March 1, 2015

Geographic coordinate system, decimal degrees

North American Datum of 1983

Figure 4. Oil and gas production wells in the Cherokee Platform Province area (IHS Markit ${ }^{\mathrm{TM}}$, 2014). 


\section{Petroleum Assessment Terminology and Methodology}

In this publication, the term "hydrocarbons" is used to denote molecules composed of hydrogen and carbon, whereas the term "petroleum" is used to denote mixtures of liquid or gaseous hydrocarbons that may also include helium and hydrocarbon compounds containing sulfur, nitrogen, oxygen, and metals. The assessment of undiscovered petroleum resources is possible because petroleum is distributed in groups of accumulations that share common geological attributes (Houghton and others, 1993). An accumulation of petroleum is often called a field, which is defined as "... an individual producing unit consisting of a single pool or multiple pools of petroleum related to each other based on a single structural or stratigraphic feature." (Gautier and others, 1995, p. 6). Furthermore, the chemical compositions of petroleum in a given field can often be correlated with the chemical compositions of organic matter in specific stratigraphic intervals indicating the source of the petroleum.

\section{Petroleum System}

The definition of a petroleum system includes (1) a source rock for the petroleum, (2) the physical and chemical characteristics of the petroleum derived from that source rock, and (3) all the geologic elements and processes that are essential for a petroleum accumulation to exist (Magoon and Dow, 1994). The geologic elements and processes of the petroleum systems include (1) source-rock physical characteristics and chemical and mineralogical compositions; (2) source-rock organic-matter thermal maturation; (3) petroleum compositions and migration pathways; and (4) characterizations of the reservoir rocks, traps and seals.

Petroleum systems may be classified as known, hypothetical, or speculative systems (Magoon and Dow, 1994). For known systems, geochemical studies show correlation between hydrocarbons contained within the petroleum source rock and a petroleum accumulation. Hypothetical systems have a source rock identified by geochemical information but no known geochemical correlation between the petroleum source rock and a petroleum accumulation. Speculative systems do not have a source rock identified by geochemical information, but the existence of either a petroleum source rock or a petroleum accumulation is postulated based on other evidence.

\section{Assessment Unit}

For a given petroleum system, the volume of rock to be assessed is divided into various reservoir intervals that share common attributes. These reservoir intervals are called assessment units and are typically defined according to stratigraphic and structural parameters. These parameters should be sufficiently homogenous such that one methodology of resource assessment is applicable to a given assessment unit. In the case of the Cherokee Platform Province, most AUs are defined according to stratigraphy and lithology.

Assessment units are classified as either conventional or continuous (unconventional) depending upon the nature of petroleum accumulation within the assessment unit (Gautier and others, 1995; U.S. Geological Survey National Oil and Gas Resource Assessment Team, 1995; Schmoker, 2005; Schmoker and Klett, 2005). Conventional assessment units contain discrete petroleum accumulations of a range of sizes, with well-defined fluid contacts (water, oil, and gas) within the reservoir. In contrast, continuous (unconventional) assessment units are petroleum accumulations that have poorly defined boundaries within the reservoir, exist more or less independently of the water column, and are pervasive over a large geographic area. Different assessment methodologies are applied to conventional assessment units and continuous (unconventional) assessment units. Figure 5 is a schematic diagram illustrating conventional and unconventional oil and gas accumulations as used in assessments by the USGS.

Conventional assessment units may be classified as established, frontier, or hypothetical. Established assessment units are defined as having more than 13 discovered petroleum accumulations that are larger than the minimum size established for the assessment (Klett and others, 2000). Frontier assessment units are defined as having 1 to 13 discovered petroleum accumulations larger than the minimum size established for the assessment. Hypothetical assessment units are defined as having no discovered accumulations of petroleum larger than the minimum size established for the assessment.

\section{Field Growth}

Perception of the size and distribution of petroleum accumulations in an area can be distorted by several artefacts of the petroleum discovery process. One artefact of this process is an emphasis on the discovery of large fields (Kontorovich and others, 2001). Larger petroleum fields are easier to discover; hence, larger fields tend to be discovered earlier in the exploration history, and the number of discoveries per well tends to decline as more wells are drilled (Kaufman, 1993; Root and Mast, 1993; Schuenemeyer and Drew, 1993; LaPointe, 1995). Thus, the discoverability of a petroleum field is a function of the petroleum field size. Petroleum field discoverability is also a function of the number of wells drilled in the basin. Specifically, the discoverability of a petroleum field is greater if fewer wells have been drilled in the basin (Meisner and Demirmen, 1981). Thus, the probability of an exploration success tends to decrease as more wells are drilled, and progressively more drilling is required to find a petroleum accumulation of a given size (Kaufman, 1993). Furthermore, as more wells are drilled, fewer and smaller fields are discovered causing the mode of the distribution of the magnitudes of discovered fields to decrease (Schuenemeyer and Drew, 1983; Root and Attanasi, 1993). As a result, the true average size of the underlying field 


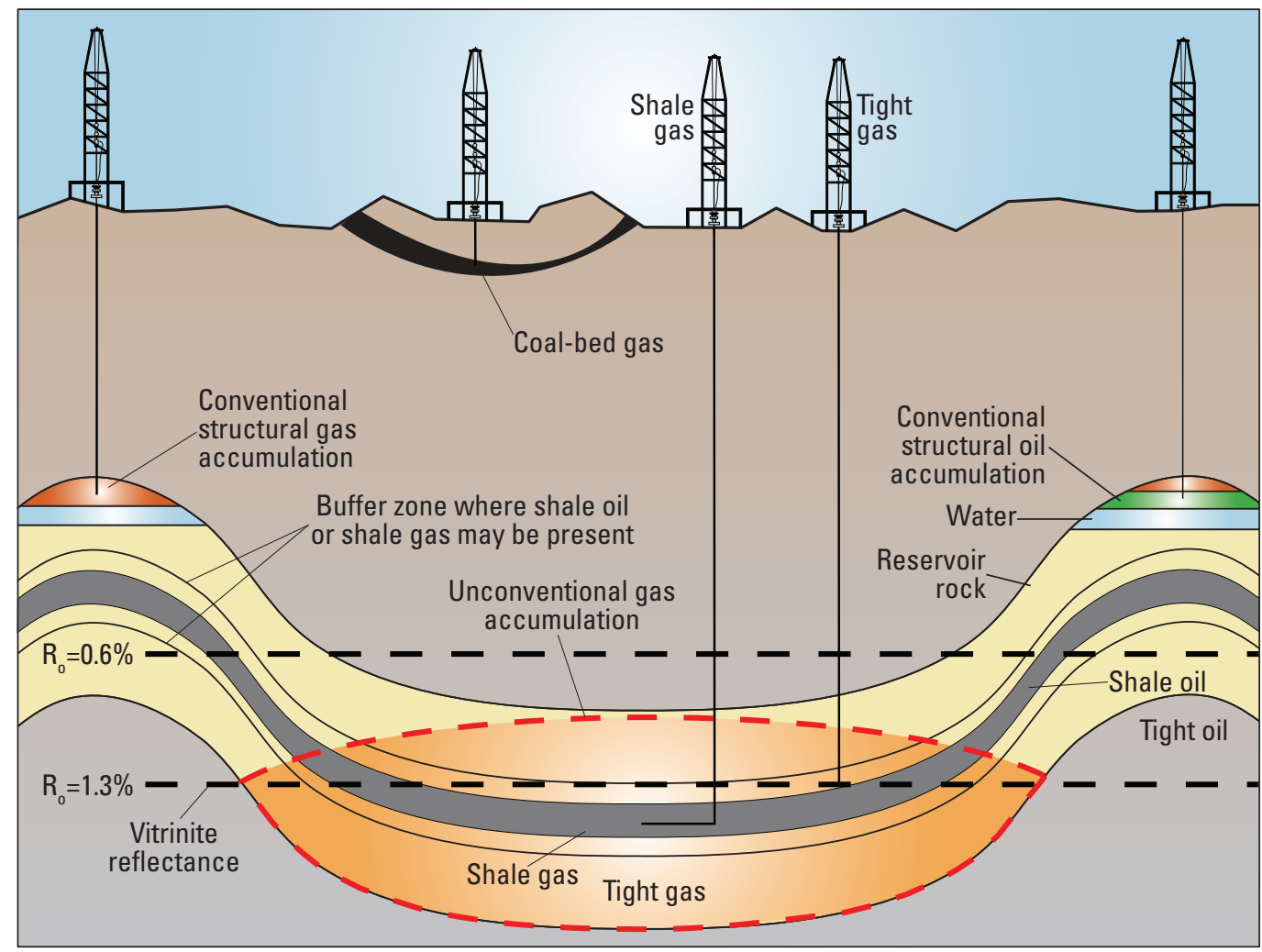

NOT TO SCALE

Figure 5. Conventional and unconventional oil and gas accumulations as used in assessments by the U.S. Geological Survey. Shale gas, shale oil, tight gas, tight oil, and coalbed gas are unconventional accumulations. $\left(\% \mathrm{R}_{0^{\prime}}=\right.$ vitrinite reflectance; figure from Schenk and Nelson, 2015).

population is less than the average size calculated early in the exploration history. Most estimates of the ultimate recoverable resources of an oil or gas field, however, eventually increase with time as more wells are drilled (Drew and Schuenemeyer, 1993). This phenomenon is referred to as field growth, and it is an artefact of the petroleum discovery process (Attanasi and Root, 1994). To account for field growth, the USGS applies a growth factor to reported field sizes in order to account for resources expected to be added to reserves as a consequence of the extension of known fields, the revision of reserve estimates, and the addition of new pools to discovered fields (U.S. Geological Survey National Oil and Gas Resource Assessment Team, 1995; Attanasi and others, 1999). Thus, in the USGS assessment terminology, grown fields are fields where the volume of oil or gas resources is the amount of estimated ultimate recoverable resources.

\section{Economic Truncation}

Economic truncation is another artefact of the petroleum discovery process distorting perception of the underlying parent population of petroleum fields (Schuenemeyer and Drew, 1983). The term refers to the fact that smaller oil and gas fields may be unreported, because they are not profitable to produce. Thus, the USGS uses a minimum field size (for grown field sizes) when working with oil and gas statistics. For the 2015 assessment of the Cherokee Platform province, the USGS used a minimum grown field size of $0.5 \mathrm{MMBO}$ for oil accumulations and a minimum grown field size of 3 BCFG for gas accumulations. These minimum grown field-size values are the same minimum field-size values used in USGS assessments of most other basins in the United States.

\section{Petroleum Source Rock Characterization}

Petroleum resource assessments are completed, in part, on evaluations of petroleum source rock potential, which is based primarily on analyses of the amounts and compositions of the organic matter in the rocks and on the thermal maturity of the organic matter. For this assessment, the amount of organic matter is measured by organic carbon content, the relative hydrogen richness of the organic matter, by hydrogen index (as measured through Rock-Eval pyrolysis), and by hydrogen/carbon ratios. The thermal maturity of organic 
matter is measured by $\mathrm{T}_{\max }$ (the temperature at which the maximum rate of hydrocarbon generation occurs in a kerogen sample during pyrolysis), vitrinite reflectance $\left(\% \mathrm{R}_{\mathrm{o}}\right)$, and conodont alteration indices. In addition, characterizations of the geochemical compositions of petroleum (oils, natural gases and natural gas liquids) originating from the sourcerock intervals are critical to the understanding of the volumes, pathways, and distances of petroleum migration for each petroleum system.

As shown by Ronov (1958), the critical minimum organic carbon content for shale to be an effective hydrocarbon source rock is 0.5 percent. The organic facies concept of Jones (1987) is used to help compare the relative hydrogen richness of organic matter in the samples and to help estimate the relative amounts of oil and(or) natural gas that will be generated when the organic matter becomes thermally mature. Jones (1987) defined a classification of organic facies (A, AB, $\mathrm{B}, \mathrm{BC}, \mathrm{C}, \mathrm{CD}$, and D) for organic matter in rocks based on microscopic and chemical characteristics of organic matter that is marginally mature with respect to petroleum generation. Organic facies A has the greatest potential to generate oil. Organic facies $\mathrm{AB}$ also has great potential to generate oil. However, organic facies B has generated most of the oil in the world. Organic facies BC usually generates both oil and gas, and organic facies $\mathrm{C}$ usually generates condensate and gas. Organic facies $\mathrm{CD}$ has a moderate capacity to generate dry gas, whereas organic facies $\mathrm{D}$ is essentially nongenerative (Jones, 1987).

\section{Petroleum Systems of the Cherokee Platform Province}

The USGS has defined three TPSs and four AUs in the Cherokee Platform Province. Identification of these three TPSs and four AUs are based on (1) petroleum source rock properties including organic carbon content, organic matter compositions, and organic matter thermal maturation; (2) composition of petroleum originating from the source-rock interval and timing of petroleum generation and migration; (3) reservoir rocks (sequence stratigraphy and petrophysical properties); and (4) petroleum traps (trap formation and timing). In stratigraphic order, from oldest to youngest, the TPSs and the AUs are:

1. Paleozoic Composite TPS and Paleozoic Conventional $\mathrm{AU}$;

2. Woodford/Chattanooga Shale TPS, Woodford Shale Oil $\mathrm{AU}$, and Woodford Biogenic Gas AU;

3. Desmoinesian Coal TPS and Desmoinesian Coalbed Gas AU.

The spatial distributions of the four AUs are shown in figure 6 .

\section{Paleozoic Composite Total Petroleum System}

The Paleozoic Composite TPS on the Cherokee Platform is defined based on the presence of petroleum source-rock intervals within the Middle Ordovician Simpson Group, the Upper Devonian to Lower Mississippian Woodford Shale and stratigraphically equivalent Chattanooga Shale, and the Middle Pennsylvanian Marmaton Group and Upper Pennsylvanian Kansas City and Lansing Groups (fig. 2, Hatch and Newell, 1999). On the Cherokee Platform, petroleum has been produced from Paleozoic reservoirs ranging in age from the Cambrian Arbuckle Group to the Permian Chase Group; these reservoirs range in depth from 180 to $8,200 \mathrm{ft}$ (Nehring Associates, Inc., 2014). The Paleozoic Composite TPS has one conventional AU, the Paleozoic Conventional AU (fig. 4).

\section{Middle Ordovician Simpson Group}

The Middle Ordovician Simpson Group (fig. 2) comprises thin, shallow-subtidal limestone, dolomite, shale, and sandstone on the shelf in northeastern Oklahoma (fig. 7; modified from Northcutt and Johnson, 1997; Suhm, 1997). Thin shales in the Simpson Group have been identified as source rocks for petroleum in areas outside the Cherokee Platform including the Forest City, Salina, Sedgwick, and Anadarko Basins (Adler and others, 1971; Burruss and Hatch, 1989; Hatch and Newell, 1999; Newell and Hatch, 2000a, 2001). The Simpson Group is absent over a broad area of the Cherokee Platform in southwestern Missouri, southeastern Kansas, and northeastern Oklahoma (fig. 7). Where present in northeastern Oklahoma, the Simpson Group thickens from northeast to southwest. Suhm (1997) shows the middle to upper Simpson Group interval thickening from less than $200 \mathrm{ft}$ in southern Tulsa County, to approximately 1,000 ft in southern Pottawatomie County. This stratigraphic interval reaches a thickness of close to 2,000 ft in the Anadarko Basin farther to the southwest.

\section{Petroleum Source Rock Characterization}

Published analyses of samples needed to help evaluate the petroleum source rock potential of the shales from the Simpson Group in the Cherokee Platform Province are not available. Hence, published analyses of samples from adjacent basins to the west and north (listed in Hatch and Newell, 1999; Newell and Hatch 2000a) were used. These samples in Kansas are from the Sedgwick Basin (including Rice, Reno, Marion, and McPherson Counties) and from Wabaunsee and Nemaha Counties; samples from Missouri are from the Forest City Basin (including Atchison County, Missouri). 


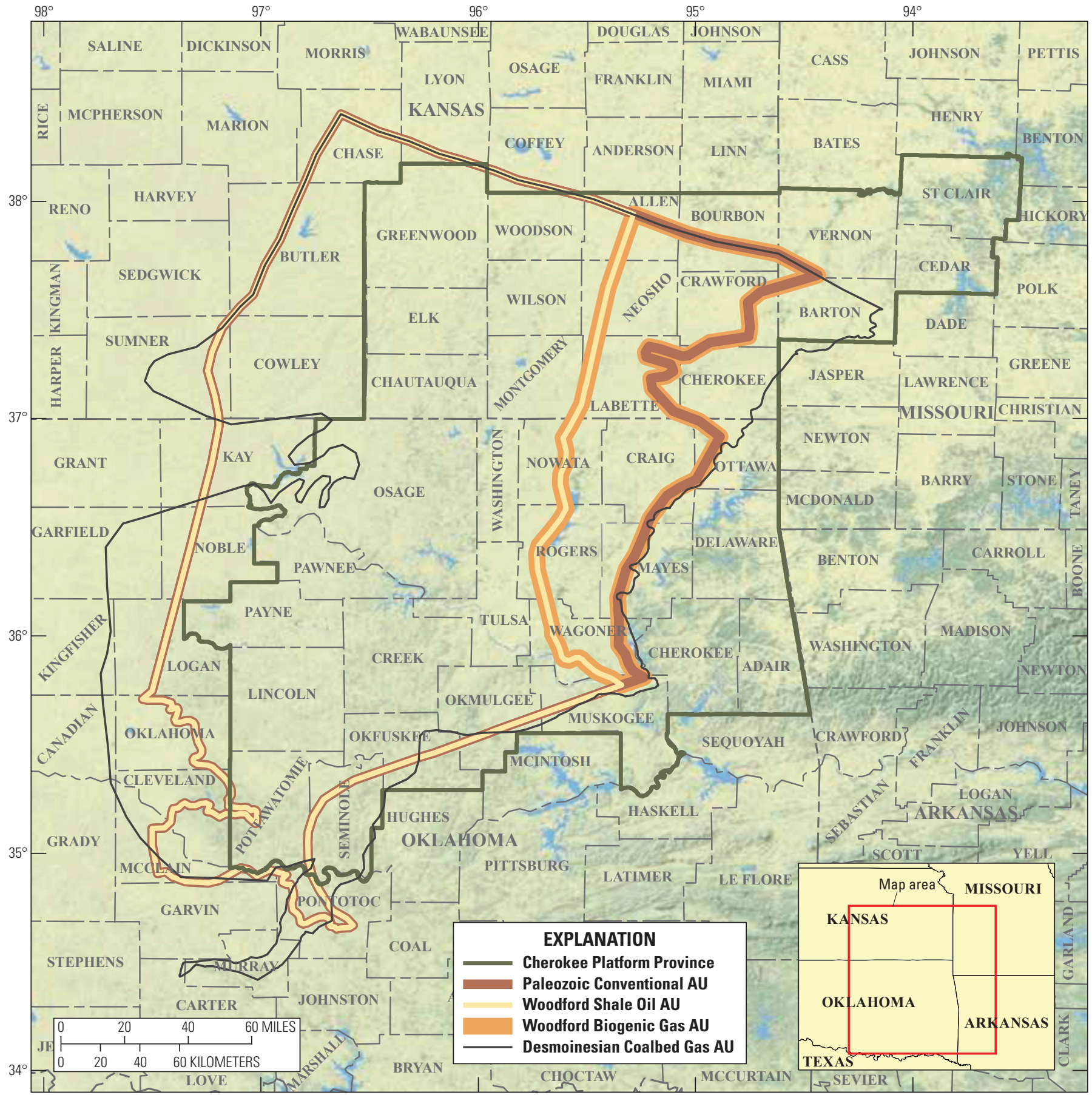

Base from U.S. National Park Service digital data, March 1, 2015

Geographic coordinate system, decimal degrees

World Geodetic System 1984 datum

Figure 6. Spatial distribution of the Paleozoic Conventional Assessment Unit (AU), the Woodford Shale Oil AU, the Woodford Biogenic Gas AU, and the Desmoinesian Coalbed Gas AU in the Cherokee Platform Province of southeastern Kansas, western Missouri, and northeastern Oklahoma. 


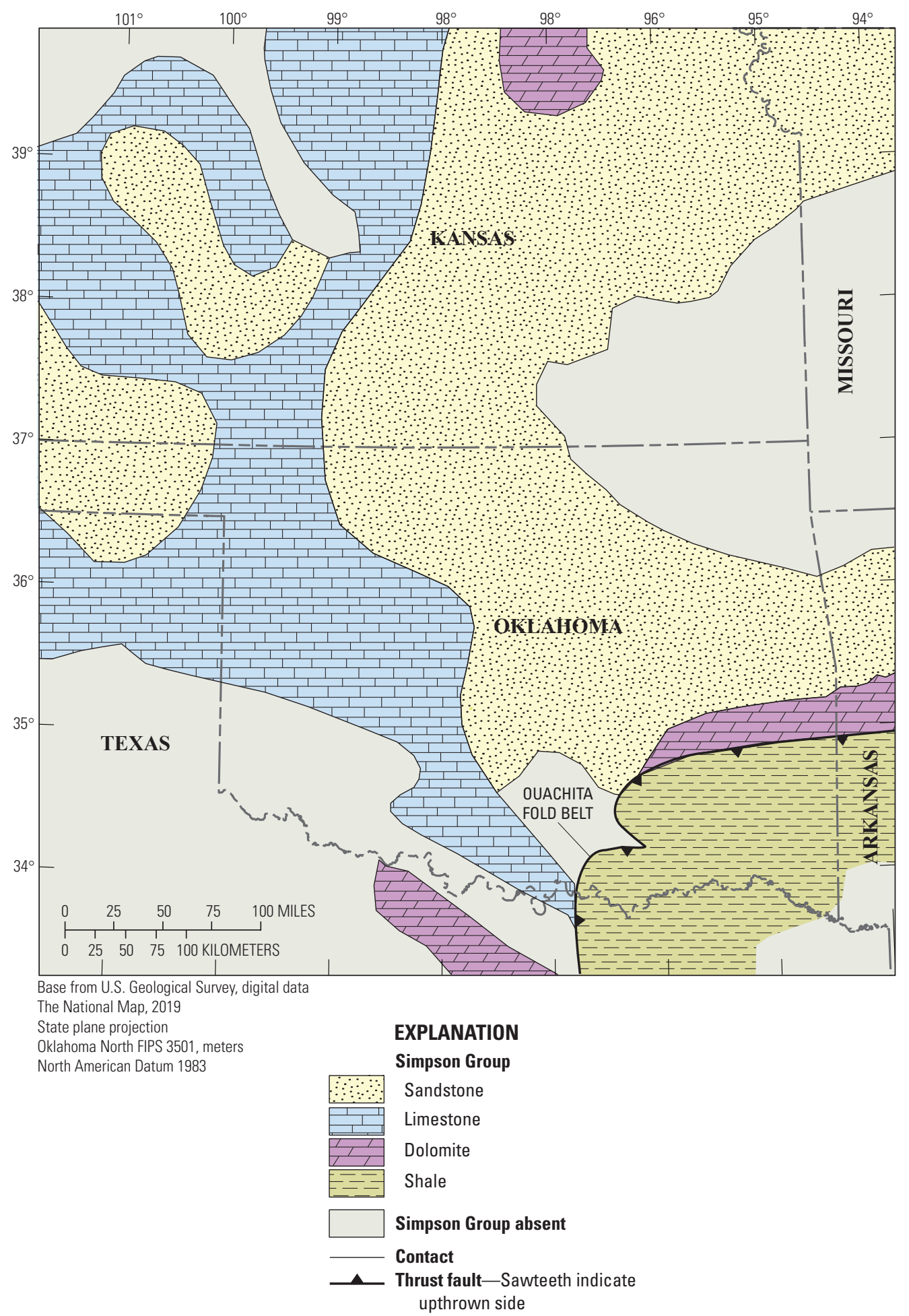

Figure 7. Extent and lithofacies of the Simpson Group (modified from Carlson and Newell, 1997; Northcutt and Johnson, 1997). 


\section{Organic Matter Contents}

The distribution of organic carbon contents (weight percent) for the 22 shale samples from the Simpson Group is shown in figure 8 . For these samples, organic carbon contents range from 0.3 to 15.8 weight percent. The distribution of organic carbon contents for the 22 samples is uneven; 17 of 22 shale samples have a 2.0 weight percent or less. The other 5 samples have more than a 6.0 weight percent. $\mathrm{T}_{\max }$ is $\leq 445$ degrees Celsius $\left({ }^{\circ} \mathrm{C}\right)$ for all samples.

\section{Organic Matter Hydrogen Richness}

The distribution of hydrogen indices (HI) for the 22 shale samples from the Simpson Group is shown in figure 9. $\mathrm{HI}$ of organic matter in the shales have an uneven distribution ranging from 7 to more than 1,000 milligrams per gram $(\mathrm{mg} / \mathrm{g})$. Organic matter compositions for 6 of the 22 shale samples are in the organic facies A or B categories, 8 samples are in the $\mathrm{BC}$ category, 5 samples are in the C category, and 3 samples are in the $\mathrm{CD}$ and $\mathrm{D}$ categories. Thus, where thermally mature, the beds of shale with facies A and B compositions would have high potential to generate oil; shales with facies $\mathrm{BC}$ compositions have potential to generate both gas and oil. Shale beds with facies $\mathrm{C}$ compositions have potential to generate gas and gas condensate, and beds with organic facies $\mathrm{CD}$ compositions have limited potential to generate dry gas (Jones, 1987).

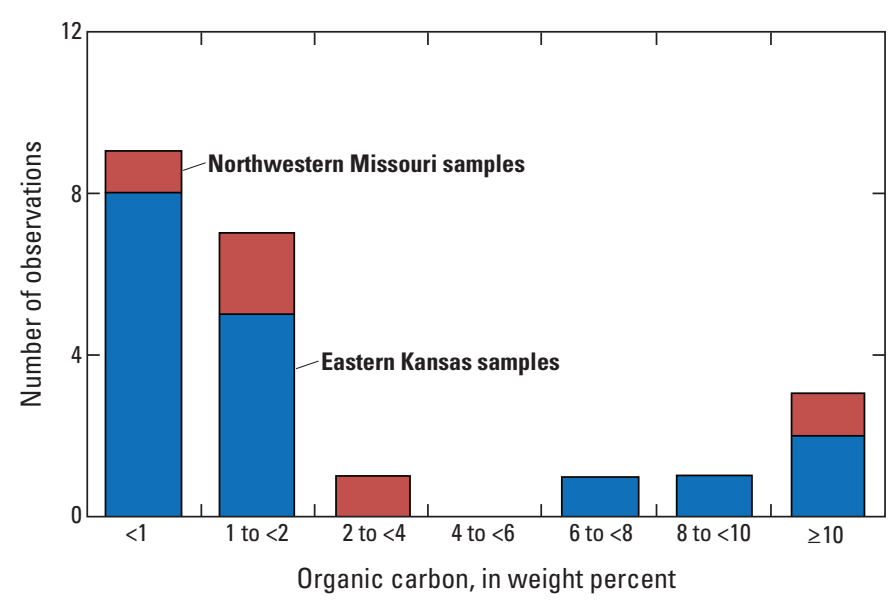

Figure 8. Histogram showing the distribution of organic-carbon contents (weight percent) for 17 shale samples from the Middle Ordovician Simpson Group from eastern Kansas and 5 samples from northwestern Missouri. Data are from Hatch and Newell (1999) and Newell and Hatch (2000b); $T_{\max }$ is $\leq 445$ degrees Celsius for all samples. $T_{\max }$ is the temperature at which the maximum rate of hydrocarbon generation occurs in a kerogen sample during pyrolysis analysis.

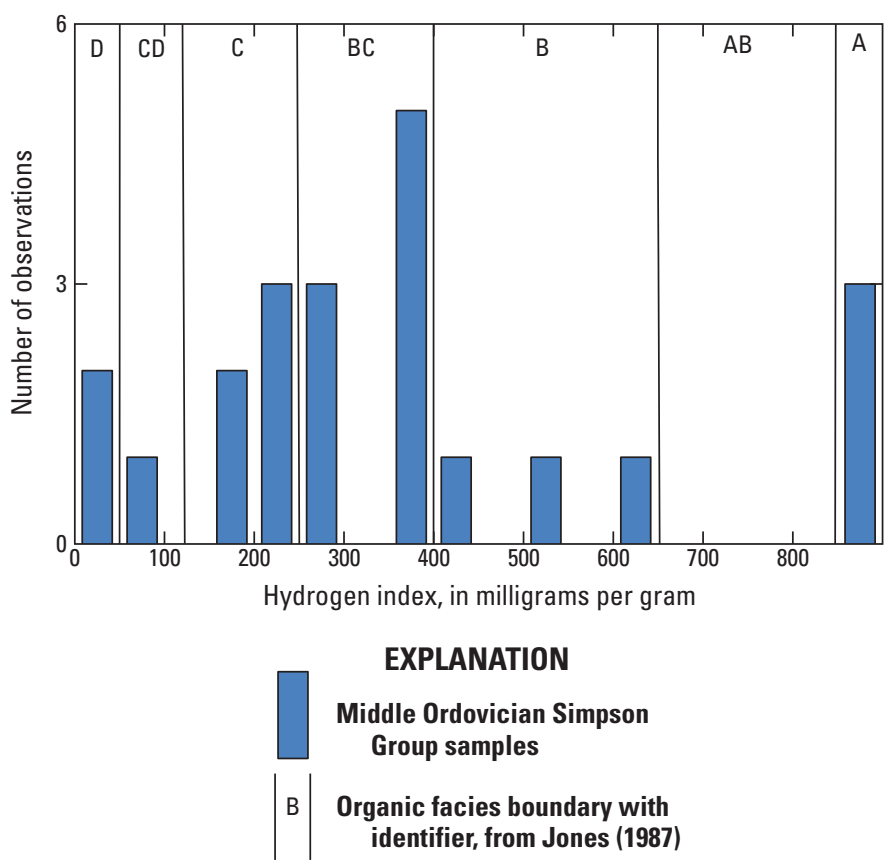

Figure 9. Distribution of hydrogen indices for 17 samples from the Middle Ordovician Simpson Group from eastern Kansas and 5 samples from northwestern Missouri. Data are from Hatch and Newell (1999) and Newell and Hatch (2000b); $T_{\max }$ is about 445 degrees Celsius for all samples. $T_{\text {max }}$ is the temperature at which the maximum rate of hydrocarbon generation occurs in a kerogen sample during pyrolysis analysis.

\section{Organic Matter Thermal Maturity}

Information is not available to help determine organic matter thermal maturity trends for the Simpson Group on the Cherokee Platform. In the Salina and Forest City Basins to the north and northwest of the Cherokee Platform in Kansas (fig. 1), thermal maturation modeling and organic matter maturation data indicate that the organic matter in the lower Paleozoic rocks in the axes of both basins is in the early stage of petroleum generation (Newell, 1997; Newell and others, 1997). Where the Simpson Group is located in the southwestern part of the Cherokee Platform, organic matter thermal maturity trends can be approximated using the data on the thermal maturity of the Woodford Shale that is discussed in the Woodford Shale and Chattanooga Shale section of the report and estimating an additional correction to account for the deeper burial.

\section{Woodford Shale and Chattanooga Shale}

The Upper Devonian to Lower Mississippian Woodford Shale in Oklahoma and the stratigraphically equivalent Chattanooga Shale in Kansas are dark gray to black fissile shales that also contain chert and siliceous shale. As shown in figure 10, the Woodford Shale has an average thickness of close to $50 \mathrm{ft}$ on the Cherokee Platform in northeastern Oklahoma 


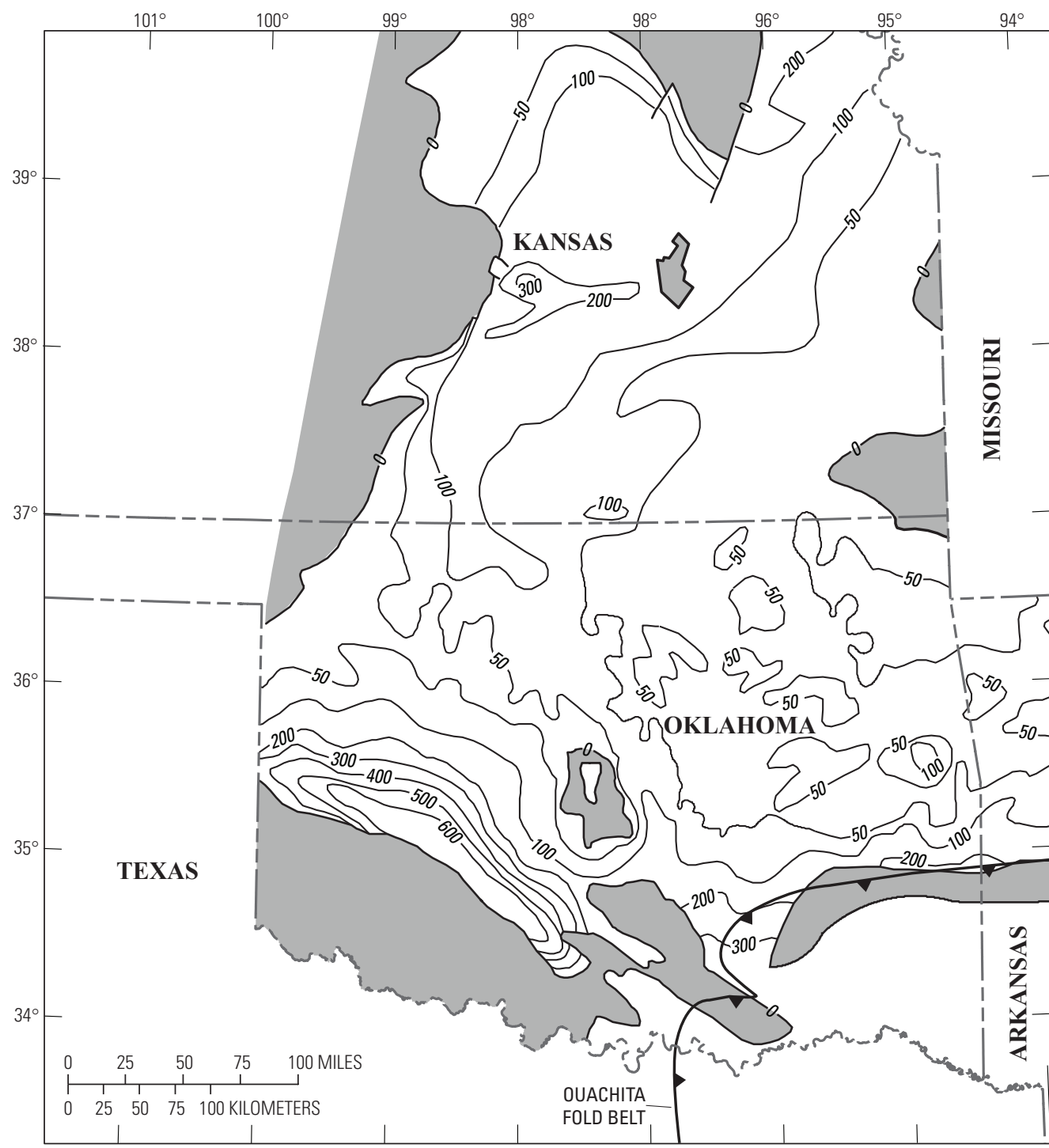

Base from U.S. Geological Survey, digital data

The National Map, 2019

State plane projection

Oklahoma North FIPS 3501, meters

EXPLANATION

North American Datum 1983

No Woodford Shale or Chattanooga

Shale present

-300- Isopach contour-Shows thickness of Woodford Shale and Chattanooga

Shale. Contour interval 50 and 100 feet.

Fault

_ـ Thrust fault-Sawteeth indicate upthrown side

Figure 10. Upper Devonian strata in Oklahoma, Arkansas, and Kansas. Modified from Comer (1990) and Lambert (1992). 
and can be up to $200 \mathrm{ft}$ thick in the southern platform area. The Woodford Shale thins to the northeast and is missing in the northeastern-most corner of Oklahoma. In southeastern Kansas, the Chattanooga Shale is approximately $100 \mathrm{ft}$ thick on the western side of the Cherokee Platform, thins to the east, and is missing from areas on the eastern border with Missouri.

\section{Petroleum Source Rock Characterization}

Petroleum has been produced from the Woodford and Chattanooga Shales at depths of about $500 \mathrm{ft}$ to almost 9,000 ft (IHS Markit $\left.{ }^{\mathrm{TM}}, 2014\right)$. Published analyses of samples used to illustrate the petroleum source rock potential of the
Woodford and Chattanooga Shales on the Cherokee Platform and adjacent areas are from Comer (1990), Hatch and Newell (1999), and Newell and Hatch (2000b). $\mathrm{T}_{\max }$ is $\leq 445^{\circ} \mathrm{C}$ or vitrinite reflectance $\left(\% \mathrm{R}_{\mathrm{o}}\right) \leq 0.60$ percent for all samples. $\mathrm{T}_{\max }$ is the temperature at which the maximum rate of hydrocarbon generation occurs in a kerogen sample during pyrolysis analysis.

\section{Organic Matter Contents}

The organic carbon contents (weight percent) for the Woodford Shale in the Cherokee Platform Province of northeastern Oklahoma are 2-4 percent as shown in figure 11. The distributions of the averaged organic carbon contents for

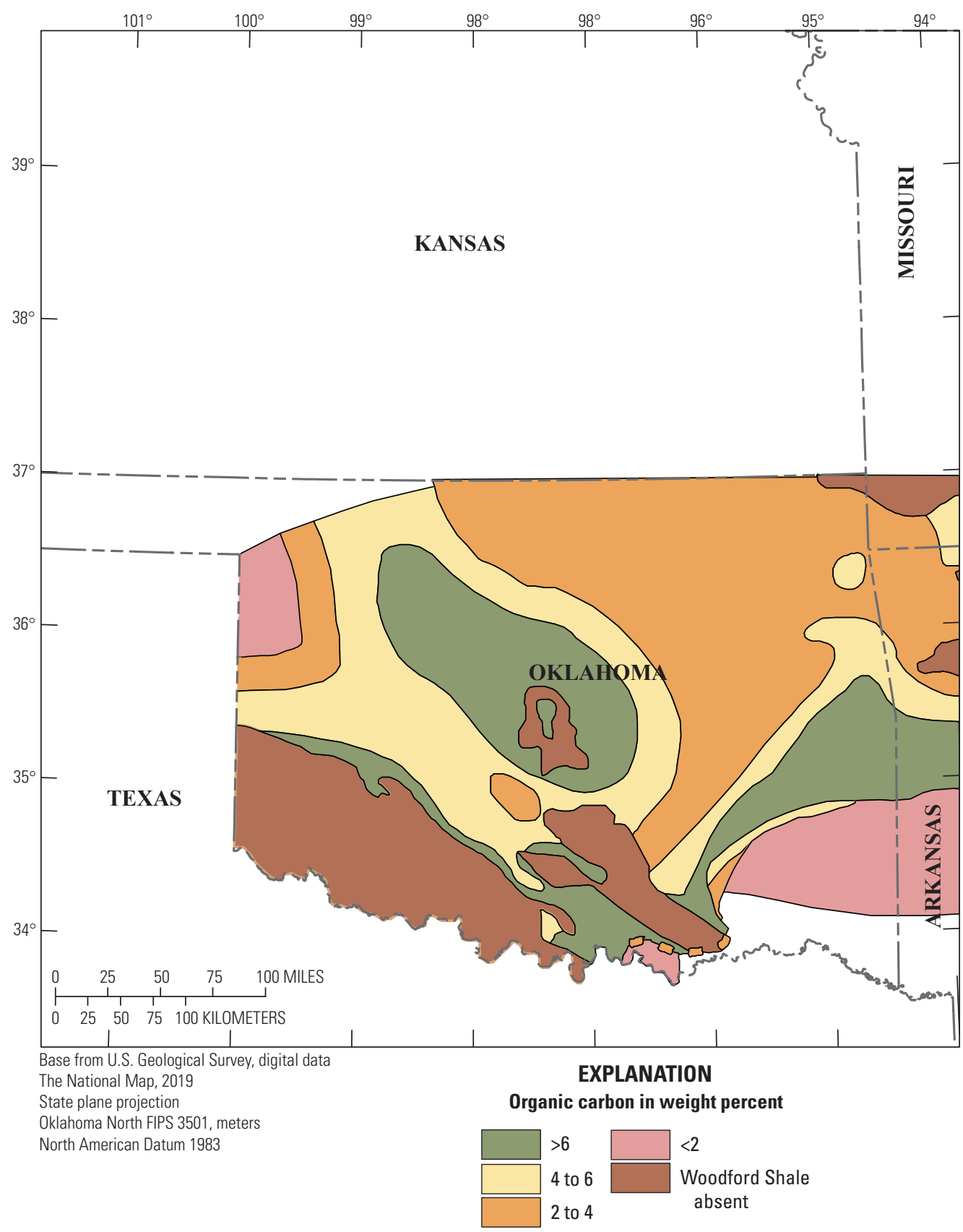

Figure 11. Distribution of organic carbon contents for the Woodford Shale in Oklahoma. Modified from Comer (2005). 
samples from 4 cores of the Woodford and Chattanooga Shale samples from eastern Kansas and for 14 cores from central and south-central Oklahoma are shown in figure 12. Figure 11 and the data from the two sample sets illustrated in figure 12 show that organic carbon contents of the Chattanooga Shale on the Cherokee Platform in eastern Kansas are generally lower than organic carbon contents of the Woodford Shale farther south in central and south-central Oklahoma.

\section{Organic Matter Hydrogen Richness}

The distributions of the averaged hydrogen indices (HI, mg hydrocarbon content/g organic carbon) for the samples from cores of the Woodford and Chattanooga Shales in eastern Kansas (4 cores) and from central and south-central Oklahoma (14 cores) are shown in figure $13 . \mathrm{T}_{\max }$ is $\leq 445^{\circ} \mathrm{C}$ or $\mathrm{R}_{\text {o }}$ $\leq 0.60$ percent for all samples. Organic matter compositions for the Woodford Shale core samples from central and southcentral Oklahoma are significantly more oil prone than organic matter in the core samples of Chattanooga Shale from eastern Kansas. Compositions of Oklahoma Woodford Shale samples range from organic facies $\mathrm{BC}$ to $\mathrm{AB}$ and should primarily generate oil when thermally mature. The Kansas Chattanooga Shale samples have organic facies BC compositions and should primarily generate gas with some oil when thermally mature (Jones, 1987).

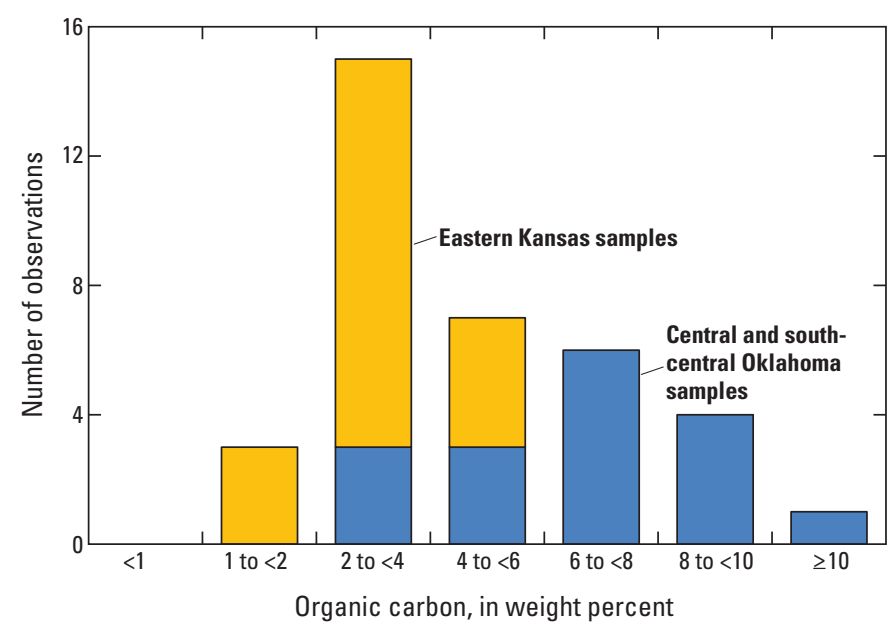

Figure 12. Distributions of the average organic carbon contents for samples from 4 cores of the Woodford and Chattanooga Shales from eastern Kansas and from 14 cores from central and south-central Oklahoma. Data are from Comer (1990), Hatch and Newell, (1999), and Newell and Hatch (2000b). $T_{\max }$ is $\leq 445$ degrees Celsius or vitrinite reflectance $\left(\% \mathrm{R}_{0}\right) \leq 0.60$ percent for all samples. $\mathrm{T}_{\max }$ is the temperature at which the maximum rate of hydrocarbon generation occurs in a kerogen sample during pyrolysis analysis.

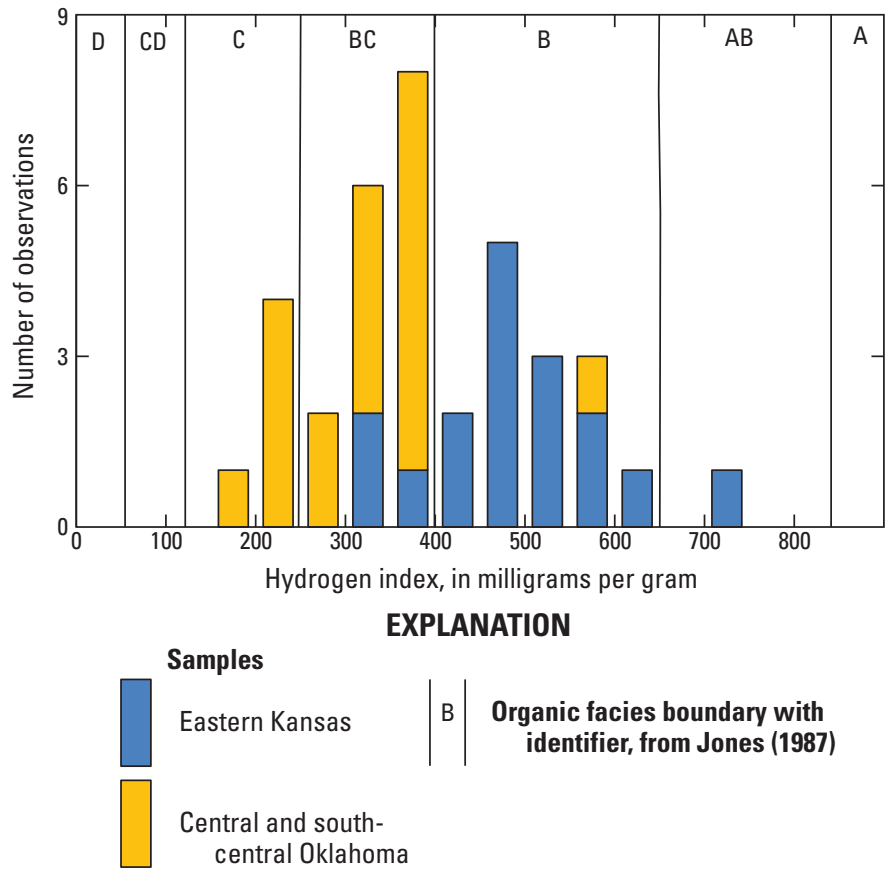

Figure 13. Distributions of the average Rock-Eval hydrogen indices for samples from 4 cores of the Woodford and Chattanooga Shales from eastern Kansas and from 14 cores from central and south-central Oklahoma. Data are from Comer (1990), Hatch and Newell, (1999), and Newell and Hatch (2000b). $T_{\max }$ is $\leq 445$ degrees Celsius, or vitrinite reflectance $\left(\% R_{0}\right) \leq 0.65 \%$ for all samples. $T_{\max }$ is the temperature at which the maximum rate of hydrocarbon generation occurs in a kerogen sample during pyrolysis analysis.

\section{Organic Matter Thermal Maturity}

Figure 14 shows the vitrinite reflectance $\left(\% R_{0}\right)$ map for eastern Oklahoma (Cardott, 2012b). $\mathrm{R}_{\mathrm{o}}$ for organic matter in the Woodford Shale is highly variable ranging from a low of 0.49 percent in Creek County, Oklahoma, on the Cherokee Platform, to more than 4 percent for organic matter in Le Flore County, near the Choctaw fault in the Arkoma Basin. Except for some anonymously high $\mathrm{R}_{\mathrm{o}}$ measures for Woodford Shale organic matter in southern Osage County and northern Pawnee County, organic matter thermal maturity on the Oklahoma part of the Cherokee Platform generally increases from northwest to southeast into the Arkoma Basin.

Figure 15 is a crossplot showing the relation between the average $\mathrm{HI}$ and average $\mathrm{R}_{\mathrm{o}}$ for 18 sets of Woodford Shale core samples that are primarily from central and south-central Oklahoma, as well as 19 sets of Woodford Shale outcrop samples primarily from eastern and southeastern Oklahoma and from northwestern Arkansas. Data are from Comer (2005). This plot shows a significant decrease in the highest average HI values between $\mathrm{R}_{\mathrm{o}}$ about 0.6 percent and about 0.8 percent. For the Woodford Shale, the highest average HI values 


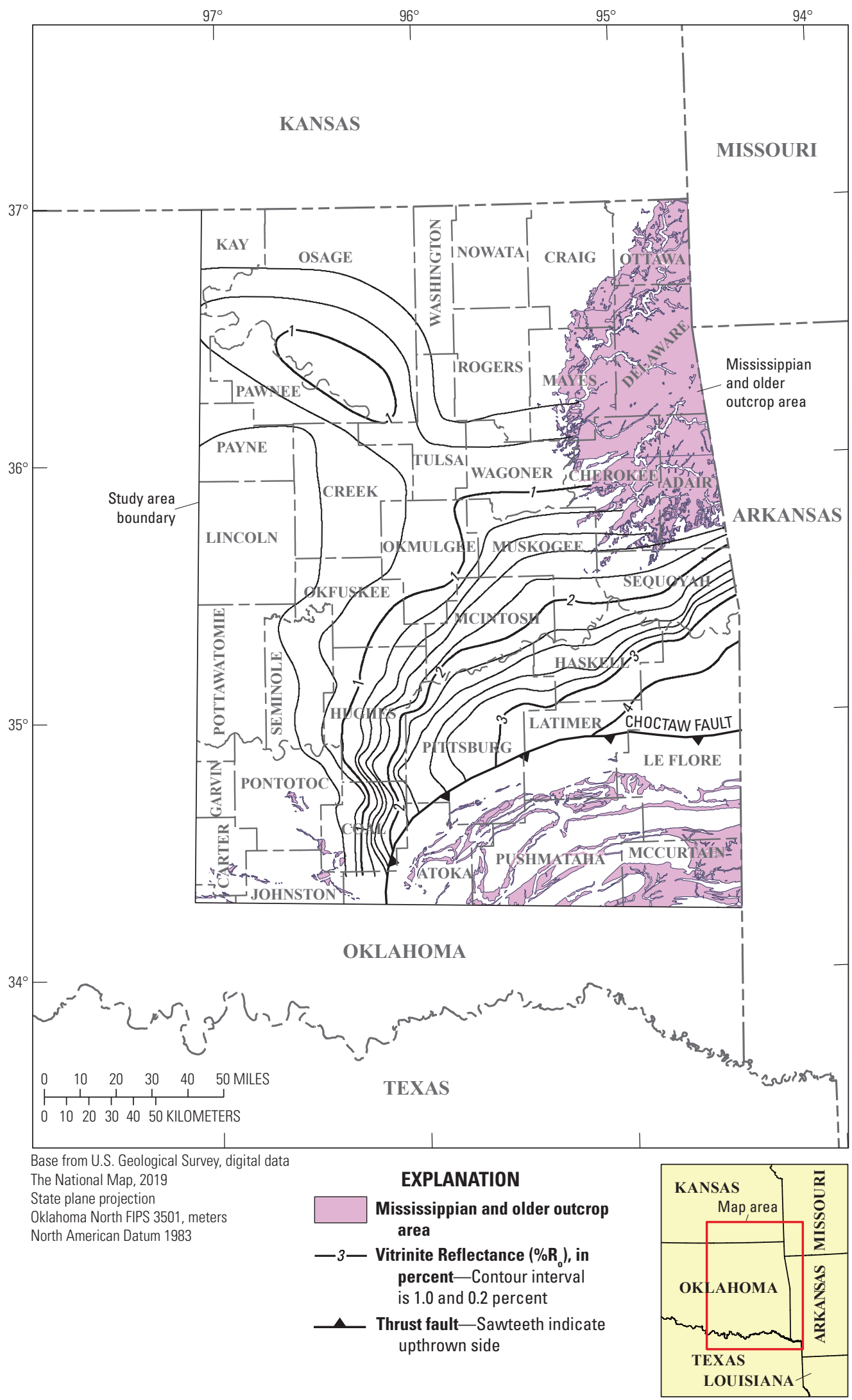

Figure 14. Vitrinite reflectance of the Woodford Shale (modified from Cardott, 2012b). 


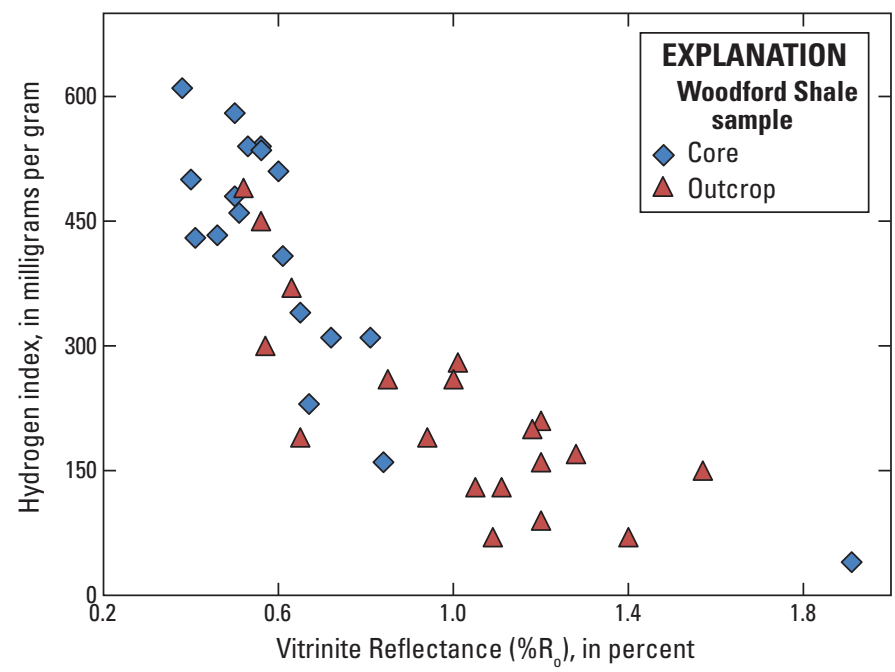

Figure 15. Relation between the average hydrogen index and average $\mathrm{R}_{0}$ for 18 sets of Woodford Shale core samples that are primarily from central and south-central Oklahoma and 19 sets of Woodford Shale outcrop samples that are primarily from eastern and southeastern Oklahoma and from northwestern Arkansas. Data are from Comer (2005).

decrease from between 450 to $600 \mathrm{mg} / \mathrm{g}$ to about $300 \mathrm{mg} / \mathrm{g}$ or less. Assuming that the bulk organic matter compositions of the outcrop shales have not been significantly altered by weathering, it appears that the decreases in $\mathrm{HI}$ between $\mathrm{R}_{\mathrm{o}}$ of approximately 0.6 percent and approximately 0.8 percent indicate a significant increase in thermogenic generation and expulsion of petroleum.

\section{Middle and Upper Pennsylvanian Marine Shales}

Rock types in the Middle and Upper Pennsylvanian of the midcontinent area have long been recognized as recording intervals of cyclical sedimentation (cyclothems)(Weller, 1930; Moore, 1931, 1936; Wanless and Weller, 1932). The black marine shales within the cyclothems are thin $(0.3$ to $5 \mathrm{ft}$ ), nonsandy, dark gray to black, phosphatic, and represent deposition at the time of maximum transgression (high-stand) of the Pennsylvanian seas. Thinness, great lateral persistence, conspicuous nonskeletal phosphorite, and abundant organic matter all point to deposition of these shales under conditions of detrital sediment starvation, with little or no bottom water oxygen (Heckel, 1977, 1986, 1991). Within the Middle and Upper Pennsylvanian sections in the midcontinent, at least 20 of these shale horizons extend up to 370 miles along outcrop. In Kansas and Oklahoma, these thin, black, phosphatic shales have been identified as petroleum source rocks (Burruss and Hatch, 1989; Hatch and Newell, 1999).

\section{Petroleum Source Rock Characterization}

The petroleum source rock potential of the Middle and Upper Pennsylvanian, thin, black marine shales on the
Cherokee Platform were evaluated using data from Hatch and others (1984), Hatch and Leventhal (1992), Hatch and Newell (1999), Newell and Hatch (2000b), and unpublished USGS analyses from five Kansas Geological Survey drill cores (Green Acres \#1, Bourbon County; Hines \#1, Neosho County; Joe Newland \#1, Wilson County; and Clarkson \#1 and Clarkson \#2, Montgomery County). The unpublished analyses are available from the U.S. Geological Survey Energy Geochemistry Database at https://certmapper.cr.usgs.gov/data/apps/ geochem-db/. The analyses from the Kansas Geological Survey cores as well as core from the Carter G.H. Davis \#2A well in Wabaunsee County are of representative incremental samples of the Upper Pennsylvanian (Missourian) Hushpuckney Shale Member of the Swope Limestone or the Stark Shale Member of the Dennis Limestone both from the Kansas City Group.

\section{Organic Matter Contents}

The distributions of organic carbon contents (weight percent) for the 47 shale samples from the Marmaton Group (8 samples) and Kansas City Group (39 samples) are shown in figure 16. For these samples, organic carbon contents range from 1.6 to 39.5 weight percent. Organic carbon contents for 23 of 47 shale samples were 16 weight percent or higher. $\mathrm{T}_{\max }$ is $\leq 440{ }^{\circ} \mathrm{C}$ for all samples.

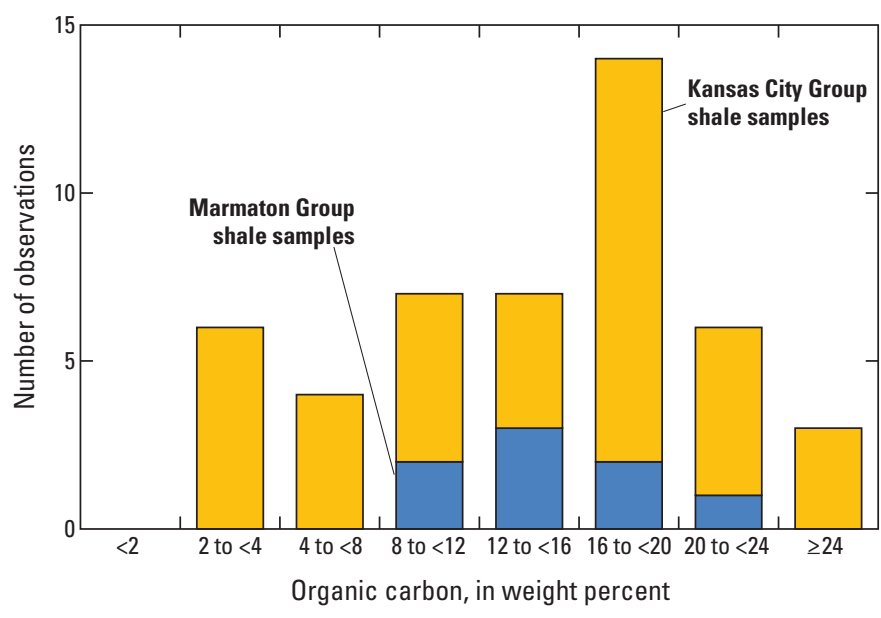

Figure 16. Distribution of organic carbon contents for 47 shale samples from the Desmoinesian Marmaton Group (8 samples) and the Missourian Kansas City Group (39 samples) from southeastern Kansas and northeastern Oklahoma. Data are from Hatch and others (1984), Hatch and Leventhal (1992), Hatch and Newell (1999), Newell and Hatch (2000b), and unpublished U.S. Geological Survey data from core from five Kansas Geological Survey drill cores from Bourbon, Neosho, Wilson, and Montgomery Counties, Kansas. $T_{\max }$ is $\leq 440$ degrees Celsius for all samples. $T_{\text {max }}$ is the temperature at which the maximum rate of hydrocarbon generation occurs in a kerogen sample during pyrolysis analysis. 


\section{Organic Matter Hydrogen Richness}

The distributions of $\mathrm{HI}$ for the 47 shale samples from the Marmaton and Kansas City Groups are shown in figure 17. HI values of organic matter in the shales range from 110 to $460 \mathrm{mg} / \mathrm{g}$. The distribution of HI for the Marmaton Group shale samples is similar to the distribution for the Kansas City Group samples. Organic matter compositions for 12 of the 47 shale samples are in the organic facies $\mathrm{CD}$ and $\mathrm{C}$ categories, 29 samples are in the organic facies BC category, and 6 samples are in the facies B category (fig. 17). Where thermally mature, the beds of shale with organic facies $\mathrm{CD}$ and $\mathrm{C}$ compositions have potential to generate gas and gas condensate, beds with organic facies $\mathrm{BC}$ compositions have potential to generate both gas and oil, and beds with facies B compositions should primarily generate oil (Jones, 1987).

\section{Organic Matter Thermal Maturity}

Determination of the regional organic matter thermal maturity trend for the Kansas City Group black marine shales is problematic because the samples only represent six

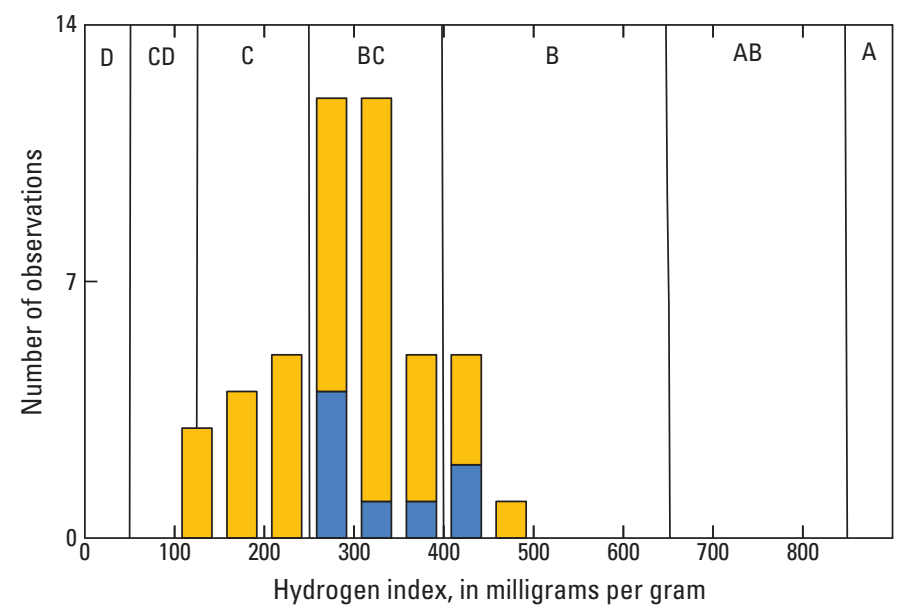

EXPLANATION

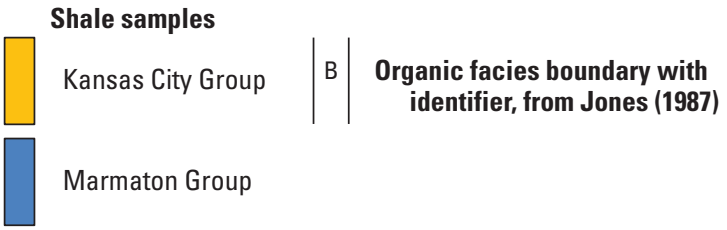

Figure 17. Distribution of hydrogen indices for 47 shale samples from the Desmoinesian Marmaton Group (8 samples) and the Missourian Kansas City Group (39 samples) from southeastern Kansas and northeastern Oklahoma. Data are from Hatch and others (1984), Hatch and Leventhal (1992), Hatch and Newell (1999), Newell and Hatch (2000b), and unpublished U.S. Geological Survey data from core from five Kansas Geological Survey drill cores from Bourbon, Neosho, Wilson, and Montgomery Counties, Kansas. $T_{\text {max }}$ is $\leq 440$ degrees Celsius for all samples. $T_{\max }$ is the temperature at which the maximum rate of hydrocarbon generation occurs in a kerogen sample during pyrolysis analysis. locations in Kansas. However, based on the distribution of the six sets of samples, there is a general north to south increase in thermal maturity as measured by $\mathrm{T}_{\max }$. For the Wabaunsee County samples, the $\mathrm{T}_{\max }$ range is from 420 to $432{ }^{\circ} \mathrm{C}$; Bourbon County, 429 to $438{ }^{\circ} \mathrm{C}$; Wilson County, 430 to $448{ }^{\circ} \mathrm{C}$; and for Montgomery County, 435 to $444{ }^{\circ} \mathrm{C}$ (see fig. 6 for county locations). These $\mathrm{T}_{\text {max }}$ measurements show that the thermal maturity of organic matter in the shales ranges from immature to mature with respect to petroleum generation.

Thermal maturity also generally increases north to south, as measured by $\mathrm{T}_{\max }$, for the 16 Marmaton Group shale samples. For two samples from Bates County, Missouri, $\mathrm{T}_{\max }$ is $439^{\circ} \mathrm{C}$ and $441{ }^{\circ} \mathrm{C}$, and for two samples from Greenwood County, Kansas, $\mathrm{T}_{\max }$ is $440{ }^{\circ} \mathrm{C}$ and $442^{\circ} \mathrm{C}$. In Oklahoma, $\mathrm{T}_{\max }$ for four samples from Craig County ranges from $441{ }^{\circ} \mathrm{C}$ to $447^{\circ} \mathrm{C}$, for four samples from Rogers County, $\mathrm{T}_{\max }$ ranges from 438 to $444^{\circ} \mathrm{C}$ and for five samples from Osage County, $\mathrm{T}_{\max }$ ranges from 449 to $458^{\circ} \mathrm{C}$. These measurements show that the organic matter in the shales is thermally mature with respect to petroleum generation.

A crossplot of HI and $\mathrm{T}_{\max }$ for 16 Marmaton Group samples and 39 Kansas City Group samples from southeastern Kansas and northeastern Oklahoma is shown in figure 18. This plot shows a large decrease in the highest $\mathrm{HI}$ values between a $\mathrm{T}_{\max }$ of about 440 and about $450{ }^{\circ} \mathrm{C}$. For the shales, the highest $\mathrm{HI}$ values decrease from near $400 \mathrm{mg} / \mathrm{g}$ to less than $200 \mathrm{mg} / \mathrm{g}$. These decreases suggest a large increase in the rates of generation and expulsion of petroleum within this

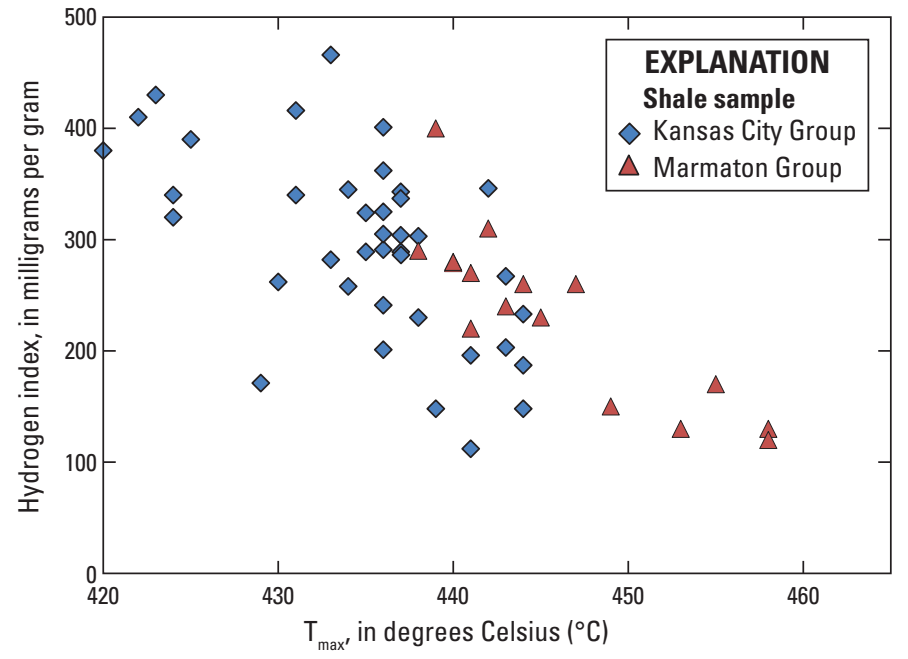

Figure 18. Relation between hydrogen index and $T_{\max }$ for 16 shale samples from the Desmoinesian Marmaton Group and 39 samples from the Missourian Kansas City Group from southeastern Kansas and northeastern Oklahoma. Data are from Hatch and others (1984), Hatch and Leventhal (1992), Hatch and Newell (1999), Newell and Hatch (2000b), and unpublished USGS data from five Kansas Geological Survey drill cores from Bourbon, Neosho, Wilson, and Montgomery Counties, Kansas. $T_{\max }$ is the temperature at which the maximum rate of hydrocarbon generation occurs in a kerogen sample during pyrolysis analysis. 
$\mathrm{T}_{\max }$ range. If the relation between $\mathrm{T}_{\max }$ and $\mathrm{R}_{0}$ discussed in the Desmoinesian Coal TPS section is appropriate for these shales, the $\mathrm{T}_{\max }$ range of 440 to $450{ }^{\circ} \mathrm{C}$ equates to a $\mathrm{R}_{\mathrm{o}}$ range from about 0.63 to 0.77 percent.

However, as shown by the oil collected from a Kansas City Group reservoir in the Davis Ranch field in Wabaunsee County, Kansas, organic matter in Middle and Upper Pennsylvanian shales with lower $\mathrm{T}_{\max }$ measures are also source rocks for petroleum. Hatch and Newell (1999) demonstrated that source rocks for the Davis Ranch field oil were thin marine shales in the Kansas City Group. Median $\mathrm{T}_{\max }$ for organic matter in these shales is $424^{\circ} \mathrm{C}$, with a range of 420 to $432{ }^{\circ} \mathrm{C}$.

\section{Petroleum Geochemistry}

\section{Oils}

Previous analyses of oils produced from the Cherokee Platform and adjacent areas of the Forest City and Anadarko Basins, (Hatch and others, 1987, 1989; Longman and Palmer, 1987; Burruss and Hatch, 1989, 1992; Hatch and Newell, 1999) document the presence of at least three geochemically distinct oil groups: (1) intervals within the Middle Ordovician Simpson Group, (2) the Upper Devonian to Lower Mississippian Woodford and Chattanooga Shales, and (3) the Middle and Upper Pennsylvanian thin marine shales.

The characteristics for the three oils, as shown by gas chromatography (fig. 19), are as follows:
1. The saturated hydrocarbon distribution for oils with a Middle Ordovician Simpson Group source is shown in figure 19. This oil, produced from the upper Ordovician Viola Limestone in the Livengood field (also known as Livingood), Brown County, Kansas (Hatch and Newell, 1999, their figure $3 A$ ), is characterized by a dominance of odd-carbon-number $n$-alkanes between $n \mathrm{C}_{10}$ and $n \mathrm{C}_{20}$ (carbon-preference index [CPI] about 1.6, modified from Bray and Evans, 1961), relatively small amounts of branched and cyclic alkanes (for example, pristane/ $n \mathrm{C}_{17}=$ about 0.07 ), low pristane/phytane (about 0.9 ), and relatively small amounts of alkanes with carbon numbers greater than $n \mathrm{C}_{19}$.

2. The saturated hydrocarbon distribution for oils with a Woodford and Chattanooga Shale source is shown in figure 20. This oil, produced from a Cherokee Group reservoir (Squirrel sand) in the Paola-Rantoul field, Miami County, Kansas, (Hatch and Newell, 1999), is characterized by smoothly decreasing amounts of $n$-alkanes, intermediate $n$-alkane to isoprenoid ratios (for example, pristane $/ n \mathrm{C}_{17}=0.55 \pm$ ), and intermediate pristane/phytane (1.56).

3. The saturated hydrocarbon distribution for oils with a Middle and Upper Pennsylvanian black marine shale source is shown in figure 21. This oil, produced from a Kansas City Group reservoir in the Davis Ranch Field, Wabaunsee County, Kansas (Hatch and Newell, 1999), is characterized by isoprenoid compounds dominant over the $n$-alkanes (for example, pristane $/ n \mathrm{C}_{17}=3.1$ ) and low pristane/phytane (0.9).

\section{Saturated hydrocarbon fraction gas chromatogram Viola Limestone, Livengood field \\ Brown County, Kansas}

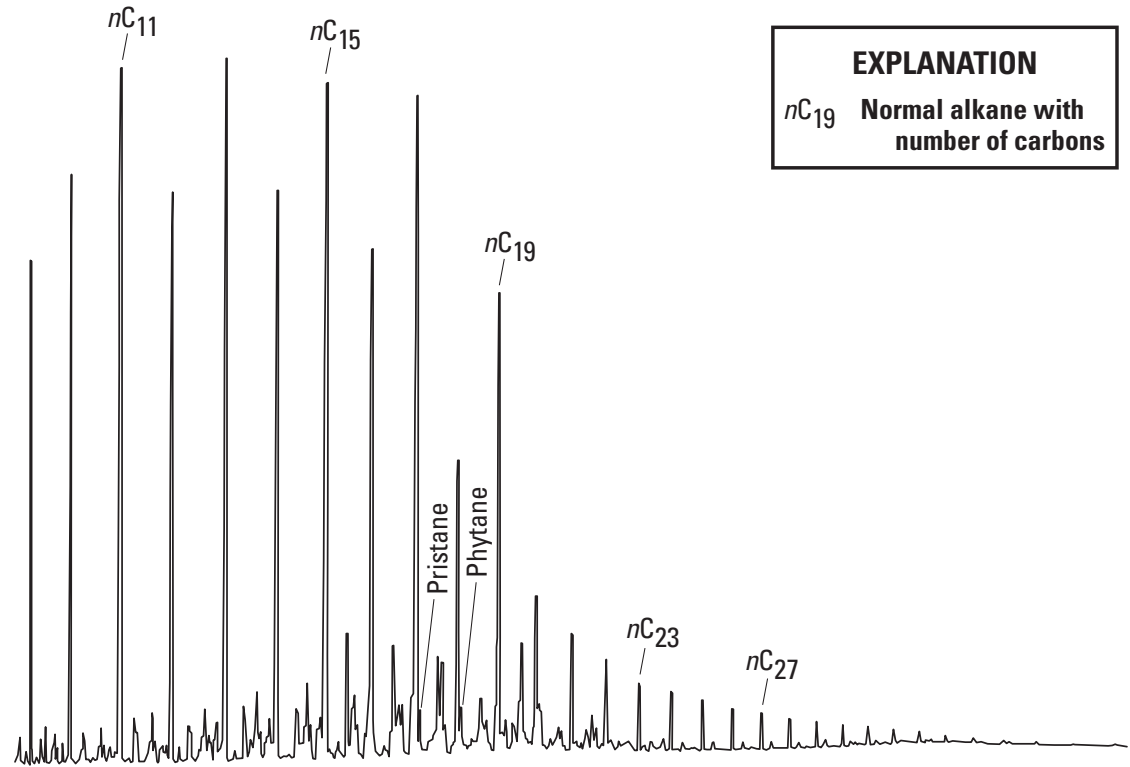

Figure 19. Saturated hydrocarbon fraction gas chromatogram for an oil collected from the Livengood (also known as Livingood) field, Brown County, Kansas. Production for this well is from a reservoir in the Upper Ordovician Viola Limestone. Production depth is not known. Modified from Hatch and Newell (1999). 
Saturated hydrocarbon fraction gas chromatogram Squirrel sand, Paola-Rantoul field

Miami County, Kansas

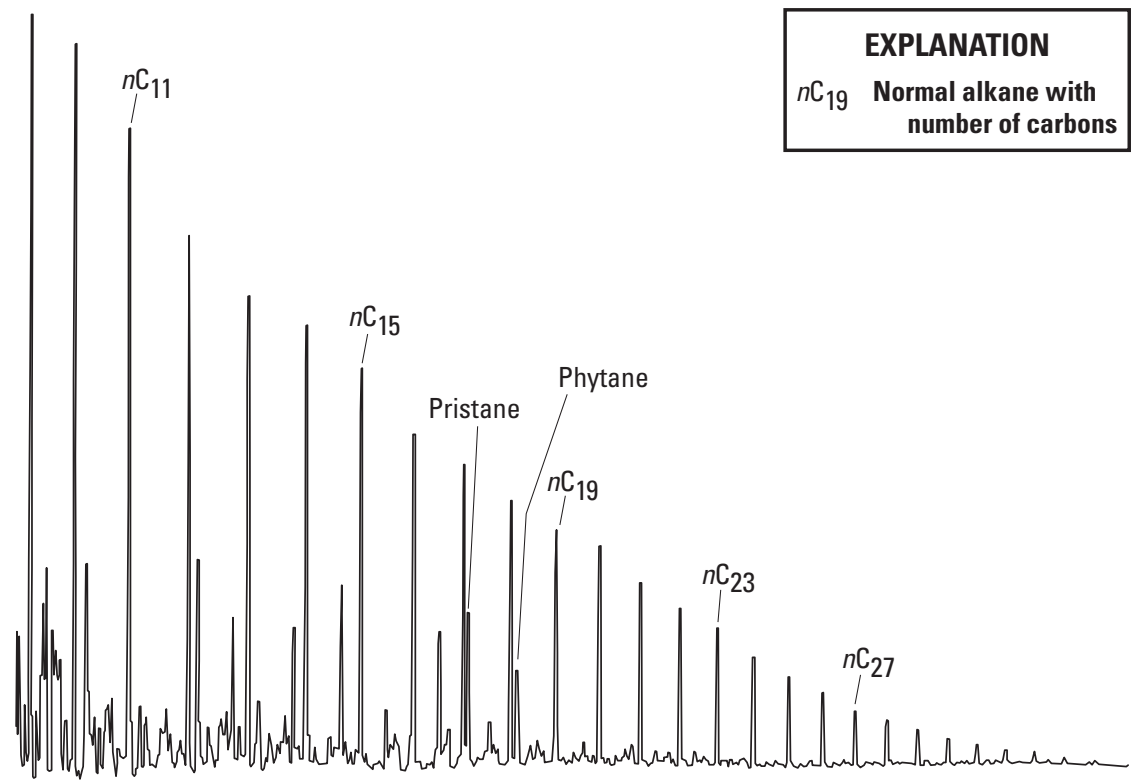

Saturated hydrocarbon fraction gas chromatogram

Kansas City Group, Davis Ranch field

Wabaunsee County, Kansas

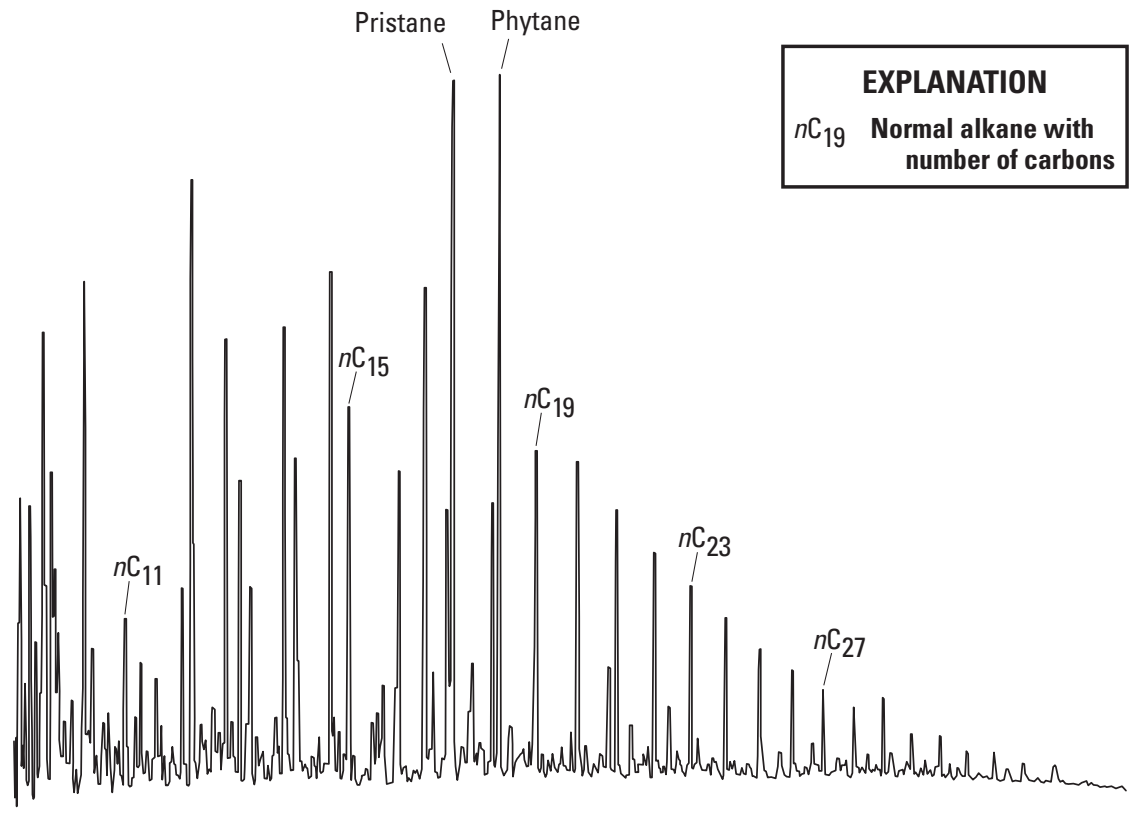

Figure 20. Saturated hydrocarbon fraction gas chromatogram for an oil collected from the Paola-Rantoul field, Miami County, Kansas. Production is from the Squirrel sand of the Middle Pennsylvanian Marmaton Group. Production depth is about 700 feet. Modified from Hatch and Newell (1999).
Figure 21. Saturated hydrocarbon fraction gas chromatogram for an oil collected from the field, Wabaunsee County, Kansas. Production for this well is from a reservoir in the Upper Pennsylvanian Kansas City Group. Production depth is 1,682 feet. Modified from Hatch and Newell (1999).
Based on analyses of 29 produced oils from 25 fields distributed throughout southeastern Kansas and northeastern Oklahoma, the primary source rocks for 28 of the oils are the Woodford and Chattanooga Shales. Production from these 25 fields was from reservoirs ranging in age from Middle Ordovician (Viola Limestone) to Late Pennsylvanian (Missourian, Layton sand). The Woodford and
Chattanooga Shales have been identified as the sources for the oils produced from traps along the basal Pennsylvanian unconformity (Mississippian chat) and from stratigraphic traps in Cherokee Group lenticular sandstone reservoirs (Burgess, Burbank, Bartlesville, Skinner, and Prue sands) (Hatch and others, 1989). For one field on the west side of the Cherokee Platform area (Haverhill field, Butler County, 
Kansas), source rocks for the oil, produced from a Kansas City Group reservoir, are the Upper Pennsylvanian black marine shales. Eight of the 28 Woodford and Chattanooga Shale sourced oils contain a small mixture of Simpson Group sourced oil as indicated by a predominance of the odd-carbonnumber $n$-alkanes between $n \mathrm{C} 10$ and $n \mathrm{C} 20$ (CPI = 1.02-1.09; modified from Bray and Evans, 1961). These eight oils are from Greenwood and Woodson Counties, Kansas, and Osage, Tulsa, and Washington Counties, Oklahoma.

\section{Natural Gases}

The chemical compositions, including measurements of nitrogen, carbon dioxide, and gas wetness of 9 natural gas samples collected from wells producing from Middle and Upper Ordovician, and Silurian and Lower Devonian (Hunton Group) reservoirs on the Cherokee Platform area of southeastern Kansas and northeastern Oklahoma are summarized in table 1; compositions for 88 natural gas samples from Mississippian and Pennsylvanian (Morrowan, Atokan, and Desmoinesian) reservoirs, are summarized in table 2; and compositions for 8 natural gas samples from upper Pennsylvanian reservoirs are summarized in table 3. The data summarized in these tables are from Moore and Sigler (1987) and Hamak and Sigler (1991). The natural gas compositions summarized in tables 1 and 2 are primarily from samples collected from reservoirs on the western side of the assessment area in Oklahoma (for example, Osage, Pawnee, Payne, and Creek Counties to the north, Lincoln, Okfuskee, Okmulgee, and Seminole Counties to the south). For samples collected from Upper Pennsylvanian reservoirs, four samples are from Elk and Chautauqua Counties, Kansas, and four samples are from Osage and Lincoln Counties, Oklahoma.

Table 1. Statistical summary of the chemical compositions of nine natural gas samples collected from wells producing from Middle and Upper Ordovician, Silurian, and Lower Devonian (Hunton Group) reservoirs on the Cherokee Platform area of northeastern Oklahoma.

$\left[\right.$ Gas wetness $($ percent $)=100 \times\left(1-\left[\mathrm{C}_{1}\right.\right.$ mole percent $/ \Sigma \mathrm{C}_{1}-\mathrm{C}_{5}$ mole percent $\left.]\right) ; \mathrm{n}$, number; $\mathrm{C} 1$, methane; $\mathrm{C} 2$, ethane; $\mathrm{C} 3$ propane; $\mathrm{C} 4$, butane; $\mathrm{C} 5$, pentane]

\begin{tabular}{lccc}
\hline \multicolumn{1}{c}{ Statistic } & $\begin{array}{c}\text { Nitrogen } \\
\text { (mole percent) }\end{array}$ & $\begin{array}{c}\text { Carbon dioxide } \\
\text { (mole percent) }\end{array}$ & $\begin{array}{c}\text { Wetness } \\
\text { (percent) }\end{array}$ \\
\hline Samples (n) & 9 & 9 & 9 \\
Median & 6.8 & 0.1 & 14 \\
Average, standard deviation & $7.6 \pm 2.4$ & $0.4 \pm 0.6$ & $13 \pm 8.4$ \\
Range & $2.6-12$ & $<0.1-1.9$ & $0.5-24$ \\
\hline
\end{tabular}

Table 2. Statistical summary of the chemical compositions of 88 natural gas samples collected from wells producing from Mississippian and Pennsylvanian (Morrowan, Atokan, and Desmoinesian) reservoirs on the Cherokee Platform area of northeastern Oklahoma.

$\left[\right.$ Gas wetness $($ percent $)=100 \times\left(1-\left[\mathrm{C}_{1}\right.\right.$ mole percent $/ \Sigma \mathrm{C}_{1}-\mathrm{C}_{5}$ mole percent $\left.]\right) ; \mathrm{n}$, number; $\mathrm{C} 1$, methane; $\mathrm{C} 2$, ethane; $\mathrm{C} 3$, propane; $\mathrm{C} 4$, butane; C5, pentane]

\begin{tabular}{lccc}
\hline \multicolumn{1}{c}{ Statistic } & $\begin{array}{c}\text { Nitrogen } \\
\text { (mole percent) }\end{array}$ & $\begin{array}{c}\text { Carbon dioxide } \\
\text { (mole percent) }\end{array}$ & $\begin{array}{c}\text { Wetness } \\
\text { (percent) }\end{array}$ \\
\hline Samples $(\mathrm{n})$ & 88 & 88 & 88 \\
Median & 6.4 & 0.2 & 13.9 \\
Average, standard deviation & $8.1 \pm 6.3$ & $0.4 \pm 0.7$ & $13.9 \pm 6.8$ \\
Range & $<0.1-38$ & $<0.1-0.3$ & $0.4-40$ \\
\hline
\end{tabular}

Table 3. Statistical summary of the chemical compositions of eight natural gas samples collected from wells producing from Upper Pennsylvanian reservoirs on the Cherokee Platform area of southeastern Kansas and northeastern Oklahoma.

$[$ Gas wetness (percent $)=100 \times\left(1-\left[\mathrm{C}_{1}\right.\right.$ mole percent $/ \Sigma \mathrm{C}_{1}-\mathrm{C}_{5}$ mole percent $\left.]\right) ; \mathrm{n}$, number; $\mathrm{C} 1$, methane; $\mathrm{C} 2$, ethane; $\mathrm{C} 3$, propane; $\mathrm{C} 4$, butane; C5, pentane]

\begin{tabular}{lccc}
\hline \multicolumn{1}{c}{ Statistic } & $\begin{array}{c}\text { Nitrogen } \\
\text { (mole percent) }\end{array}$ & $\begin{array}{c}\text { Carbon dioxide } \\
\text { (mole percent) }\end{array}$ & $\begin{array}{c}\text { Wetness } \\
\text { (percent) }\end{array}$ \\
\hline Samples (n) & 8 & 8 & 8 \\
Median & 12 & 0.1 & 15 \\
Average, standard deviation & $17 \pm 14$ & $0.1 \pm 0.1$ & $12 \pm 6.2$ \\
Range & $3.8-38$ & $<0.1-0.3$ & $2.6-18$ \\
\hline
\end{tabular}


Jenden and others (1988) used multiple parameters, isotope compositions, and cross plots to study the compositions of natural gases produced from 15 conventional reservoirs in eastern Kansas. Their analyses demonstrated that the produced natural gases have biogenic, thermogenic, and mixed biogenicthermogenic origins. The chemical compositions of nitrogen, carbon dioxide, and gas wetness of 13 natural gas samples collected by Jenden and others (1988) from wells producing from Mississippian and Middle Pennsylvanian reservoirs on the Cherokee Platform area of southeastern Kansas are summarized in table 4.

Comparison of the natural gas analyses from the Cherokee Platform area in northeastern Oklahoma (summarized in table 2) with the gas analyses from southeastern Kansas (summarized in table 4) shows similar nitrogen and carbon dioxide contents. The gas wetness of the northeastern Oklahoma natural gases, however, is twice that of the southeastern Kansas natural gases, which is likely caused by gas generation from source rocks with a higher level of thermal maturity or a lack of microbial generated gas. Samples with gas wetness values less than 3.0 percent included in tables $1-4$ have likely been biodegraded or are primarily composed of microbial gas (table 1, two samples; table 2, seven samples; table 3, two samples; and table 4, six samples).

\section{Geologic Model for Assessment}

The geologic model for the assessment of the Paleozoic Composite TPS and the Paleozoic Conventional AU is that the major petroleum source rock is the Upper Devonian to Lower Mississippian Woodford Shale and stratigraphically equivalent Chattanooga Shale. Petroleum contributions are minor from Middle Ordovician Simpson Group shales and from thin marine shales in the Middle Pennsylvanian Marmaton Group and the Upper Pennsylvanian Kansas City Group. Oil and gas generation in the Woodford Shale most likely occurred in the deeper part of the Cherokee Platform and in the deeper Anadarko and Arkoma Basins to the south (Cardott, 2012a). Petroleum migrated from these areas, apparently along faults and unconformities and through fractured and permeable carbonates and clastics, to areas of the Cherokee Platform in northeastern Oklahoma and southeastern Kansas (Burruss and Hatch, 1989).

\section{Assessment Unit Description and Input Data}

The AU area (fig. 6) is bounded on the north and west by the Bourbon arch and the Nemaha uplift, respectively, and on the east by Paleozoic outcrop and the areal extent of the Woodford Shale and Chattanooga Shale (Merriam, 1963). The southern boundary is defined, in part, by the adjacent Arkoma Basin, the extent of the Woodford Shale, and borehole data (IHS Markit $\left.{ }^{\mathrm{TM}}, 2014\right)$. The producing and source rocks for this assessment unit are shown in figure 2 and the input data for the assessment are shown in table 5. Input data for the USGS petroleum resource assessments are described in Schenk and Nelson (2015), and the results are given in table 6.

Table 4. Statistical summary of the chemical compositions of 13 natural gas samples collected from wells producing from Mississippian, Morrowan, Atokan, and Desmoinesian reservoirs on the Cherokee Platform area of southeastern Kansas. Data are from Jenden and others (1988).

[Gas wetness (percent) $=\Sigma \mathrm{C}_{2}-\mathrm{C}_{5}$ mole percent $/ \Sigma \mathrm{C}_{1}-\mathrm{C}_{5}$ mole percent; $\mathrm{n}$, number; $\mathrm{C} 1$, methane; $\mathrm{C} 2$, ethane; $\mathrm{C} 3$, propane; $\mathrm{C} 4$, butane; C5, pentane]

\begin{tabular}{lccc}
\hline \multicolumn{1}{c}{ Statistic } & $\begin{array}{c}\text { Nitrogen } \\
\text { (mole percent) }\end{array}$ & $\begin{array}{c}\text { Carbon dioxide } \\
\text { (mole percent) }\end{array}$ & $\begin{array}{c}\text { Wetness } \\
\text { (percent) }\end{array}$ \\
\hline Samples (n) & 13 & 13 & 13 \\
Median & 5.1 & 0.5 & 6.7 \\
Average, standard deviation & $9.2 \pm 8.3$ & $1.3 \pm 1.8$ & $6.5 \pm 6.7$ \\
Range & $1.2-26.1$ & $0.1-6.1$ & $<0.1-22.4$ \\
\hline
\end{tabular}


Table 5. Key assessment input data for the Paleozoic Conventional Assessment Unit in the Cherokee Platform Province (from Drake and others, 2015).

[AU, assessment unit; MMBO, million barrels of oil; BCFG, billion cubic feet of gas]

\begin{tabular}{lcccc}
\hline & Assessment input data-conventional AU & & \\
\hline \multicolumn{1}{c}{ Paleozoic conventional AU } & Minimum & Median & Maximum & Calculated mean \\
\hline Number of oil fields & 1 & 3 & 10 & 3.2 \\
Number of gas fields & 1 & 15 & 40 & 15.8 \\
Sizes of oil fields (MMBO) & 0.5 & 0.8 & 3 & 0.9 \\
Sizes of gas fields (BCFG) & 3 & 7 & 60 & 8.7 \\
\hline
\end{tabular}

Table 6. Assessment results for petroleum resources in the Paleozoic Conventional Assessment Unit in the Cherokee Platform Province area (from Drake and others, 2015).

[Results shown are fully risked estimates. For gas accumulations, all liquids are included under the natural gas liquids category. F95 represents a 95 percent chance of at least the amount tabulated. Other fractiles are defined similarly. Fractiles are additive under the assumption of perfect positive correlation. Gray shading indicates not applicable. TPS, total petroleum system; AU, assessment unit; MMBO, million barrels of oil; BCFG, billion cubic feet of gas; NGL, natural gas liquids; MMBNGL, million barrels of natural gas liquids]

\begin{tabular}{|c|c|c|c|c|c|c|c|c|c|c|c|c|c|c|}
\hline \multirow{3}{*}{ TPS and AU } & \multirow{3}{*}{$\begin{array}{c}\text { AU } \\
\text { prob- } \\
\text { ability }\end{array}$} & \multirow{3}{*}{$\begin{array}{c}\text { Accu- } \\
\text { mulation } \\
\text { type }\end{array}$} & \multicolumn{12}{|c|}{ Total undiscovered resources } \\
\hline & & & \multicolumn{4}{|c|}{ Oil (MMBO) } & \multicolumn{4}{|c|}{ Gas (BCFG) } & \multicolumn{4}{|c|}{ NGL (MMBNGL) } \\
\hline & & & F95 & F50 & F5 & Mean & F95 & F50 & F50 & Mean & F95 & F50 & F5 & Mean \\
\hline \multirow{2}{*}{ Paleozoic Conventional AU } & \multirow{2}{*}{1.0} & Oil & 1 & 3 & 5 & 3 & 0 & 2 & 8 & 3 & 0 & 0 & 0 & 0 \\
\hline & & Gas & & & & & 72 & 130 & 229 & 137 & 2 & 4 & 7 & 4 \\
\hline
\end{tabular}

\section{Woodford/Chattanooga Total Petroleum System}

\section{Assessment Units Description}

The Woodford/Chattanooga TPS is based on the presence of identified petroleum source rock intervals within the Woodford and Chattanooga Shales. The Woodford/ Chattanooga TPS has two continuous AUs: (1) the Woodford Shale Oil AU and (2) the Woodford Biogenic Gas AU. Both of these AUs (fig. 6) are bounded on the north by the Bourbon arch and on the south by the northern boundary of the Woodford Shale Gas AU of the Arkoma Basin petroleum assessment (Houseknecht and others, 2010). The Woodford Shale Oil AU is bounded on the west by the Nemaha uplift, which is also the eastern boundary of the Woodford Shale Oil AU of the Anadarko Basin petroleum assessment (Higley and others, 2014), and it is bounded on the east by the Woodford Biogenic Gas AU. The eastern boundary with the Woodford Biogenic Gas AU is where the top of the Woodford Shale is at a depth of $1,250 \mathrm{ft}$. At depths less than 1,250 ft, biogenic methane can be found (Cardott, 2012b). The eastern boundary of the Woodford Biogenic Gas AU is the outcrop and subcrop of the Woodford Shale and Chattanooga Shale.

\section{Petroleum Source Rock Characterization}

The petroleum source rock for the Woodford/Chattanooga TPS is the Upper Devonian to Lower Mississippian Woodford Shale and the stratigraphically equivalent Chattanooga Shale. Petroleum source rock characteristics, as summarized from the Woodford and Chattanooga Shale section of Paleozoic Composite TPS section of this report, include

1. For most of the Woodford/Chattanooga TPS area on the Cherokee Platform, $R_{o}$ is between 0.6 percent and 1.0 percent; in the southeast part of the Cherokee Platform area, however, $\mathrm{R}_{\mathrm{o}}$ can be as high as 3.0 percent (fig. 14).

2. The shales average approximately $50 \mathrm{ft}$ thick over most of the Cherokee Platform area and can be up to $200 \mathrm{ft}$ thick in the southern part of the AU (fig. 10).

3. Organic carbon contents (weight percent) for the Woodford Shale on the Cherokee Platform area of northeastern Oklahoma is generally 2 to 10 weight percent (fig. 11). For the Chattanooga Shale in eastern Kansas, organic carbon contents range from 1.9 to 5.0 percent, median is 3.1 percent (fig. 12). 


\section{Geologic Model for Assessment and Input Data}

The geologic models used for the AUs of the Woodford/ Chattanooga TPS are

1. For the Woodford Shale Oil AU, the model is that the Woodford and the Chattanooga Shales are both the source rock for the petroleum and the reservoir rock and that some petroleum resources remain trapped within the shale following migration of oil and gas. Petroleum has been produced from the Woodford and the Chattanooga Shales at depths ranging from 1,000 to $9,000 \mathrm{ft}$ (IHS Markit ${ }^{\mathrm{TM}}$, 2014); and
2. For the Woodford Biogenic Gas AU, the model is that methanogenesis, and(or) petroleum degradation has taken place, and the gas has been retained at shallower depths (less than 1,250 ft deep) on the Ozark uplift side of the Cherokee Platform where the shale may be more fractured and more susceptible to groundwater penetration.

The input data for the assessment of the Woodford Shale Oil AU and the Woodford Biogenic Gas AU are shown in table 7. Input data and definitions for the USGS petroleum resource assessments are described in Schenk and Nelson (2015) (fig. 5 and table 8).

Table 7. Key assessment input data for the Woodford Shale Oil Assessment Unit and the Woodford Biogenic Gas Assessment Unit in the Cherokee Platform Province (from Drake and others, 2015).

[The input for the average estimated ultimate recovery is the minimum, median, maximum, and calculated mean. AU, assessment unit; EUR, estimated ultimate recovery per well; MMBO, million barrels of oil; BCFG, billion cubic feet of gas; \%, percent]

\begin{tabular}{|c|c|c|c|c|}
\hline \multicolumn{5}{|c|}{ Assessment input data continuous AU } \\
\hline Woodford Shale Oil AU & Minimum & Mode & Maximum & Calculated mean \\
\hline Potential production area of AU (acres) & $3,000,000$ & $6,000,000$ & $11,500,000$ & $6,833,333$ \\
\hline Percentage of total AU area that is untested (\%) & 96 & 98 & 100 & 98.0 \\
\hline Success ratio $(\%)$ & 15 & 30 & 50 & 31.7 \\
\hline Woodford Biogenic Gas AU & Minimum & Mode & Maximum & Calculated mean \\
\hline Potential production area of AU (acres) & 100,000 & 350,000 & $2,480,000$ & 976,667 \\
\hline Average drainage area of wells (acres) & 60 & 80 & 100 & 80 \\
\hline Percentage of total AU area that is untested (\%) & 90 & 95 & 100 & 95.0 \\
\hline
\end{tabular}

Table 8. Assessment results for the petroleum resources of the Woodford Shale Oil Assessment Unit and the Woodford Biogenic Gas Assessment Unit in the Cherokee Platform Province area (from Drake and others, 2015).

[Results shown are fully risked estimates. For gas accumulations, all liquids are included under the natural gas liquids category. F95 represents a 95 percent chance of at least the amount tabulated. Other fractiles are defined similarly. Fractiles are additive under the assumption of perfect positive correlation. Gray shading indicates not applicable. TPS, total petroleum system; AU, assessment unit; MMBO, million barrels of oil; BCFG, billion cubic feet of gas; NGL, natural gas liquids; MMBNGL, million barrels of natural gas liquids]

\begin{tabular}{|c|c|c|c|c|c|c|c|c|c|c|c|c|c|c|}
\hline \multirow{3}{*}{ TPS and AUs } & \multirow{3}{*}{$\begin{array}{c}\text { AU } \\
\text { prob- } \\
\text { ability }\end{array}$} & \multirow{3}{*}{$\begin{array}{c}\text { Accu- } \\
\text { mulation } \\
\text { type }\end{array}$} & \multicolumn{12}{|c|}{ Total undiscovered resources } \\
\hline & & & \multicolumn{4}{|c|}{ Oil (MMBO) } & \multicolumn{4}{|c|}{ Gas (BCFG) } & \multicolumn{4}{|c|}{ NGL (MMBNGL) } \\
\hline & & & F95 & F50 & F5 & Mean & F95 & F50 & F50 & Mean & F95 & F50 & F5 & Mean \\
\hline Woodford Shale Oil AU & 1.0 & Oil & 195 & 403 & 924 & 460 & 246 & 553 & 1,345 & 644 & 2 & 6 & 16 & 7 \\
\hline Woodford Biogenic Gas AU & 1.0 & Gas & & & & & 90 & 341 & 993 & 416 & 0 & 0 & 2 & 1 \\
\hline
\end{tabular}




\section{Desmoinesian Coal Total Petroleum System}

Natural gas is produced from the coals and some coalassociated mudstones in the Desmoinesian Coal TPS in the Cherokee Platform Province of southeastern Kansas and northeastern Oklahoma. For this TPS, the coals and coalassociated mudstones are both source rocks for petroleum and reservoir rocks (Newell and others, 2004, and Cardott, 2005). The Desmoinesian Coal TPS contains a continuous accumulation and includes one $\mathrm{AU}$, the Desmoinesian Coalbed Gas AU.

\section{Petroleum Source Rock Characterization}

The Desmoinesian coals represent one of the nonmarine rock types that characterize the cyclothems of the midcontinent area (Weller, 1930; Moore, 1931, 1936; Wanless and Weller, 1932). Thirty-two coals, with thickness exceeding 14 inches are identified in the Desmoinesian stratigraphic columns in eastern Kansas and Oklahoma (Newell and others, 2004); 22 of the coals are shown in figure 23. Each coal can range in thickness from 0.1 to $6 \mathrm{ft}$; most are less than 28 inches thick. The average net coal thickness in the assessment area is about $6.5 \mathrm{ft}$; thickness ranges from about 1 to $29 \mathrm{ft}$. (fig. 22). Up to 14 coals can be found in a typical well. On the Cherokee Platform, when coals and mudstones are in close stratigraphic proximity (for example, Mulky coal (informal) and Excello Shale, fig. 23), natural gases can be coproduced from both rock types during coalbed gas recovery (Cardott, 2005).

The petroleum source rock potentials of the Desmoinesian coals and coal-associated shales and mudstones were characterized using the analytical data from Hatch and others
(1984, 1989), Barker and others (1992), and unpublished USGS analyses of cores from two Oklahoma wells (Oklahoma Geological Survey CMM-2, McIntosh County, Oklahoma, and Warren 11-24, Noble County, Oklahoma). The unpublished analyses are available from the USGS Energy Geochemistry Database at https://www.usgs.gov/energy-and-minerals/ energy-resources-program.

\section{Organic Matter Contents}

The distributions of organic carbon contents for 40 coal and 48 coal-associated shale and mudstone samples are shown in figure 24. For the 48 coal-associated shale and mudstone samples organic carbon contents range from 3.0 to 22.7 weight percent. Organic carbon contents for 25 of 40 shale and mudstone samples ranged from 8 to 16 weight percent; for 12 samples, contents were greater than 16 weight percent. For the 40 coal samples, organic carbon contents range from 30 to 77 weight percent.

\section{Organic Matter Hydrogen Richness}

The distributions of $\mathrm{HI}$ for 40 coal and 48 coal-associated shale and mudstone samples are shown in figure 25. RockEval $\mathrm{T}_{\max }$ is $\leq 450{ }^{\circ} \mathrm{C}$ for all samples. Organic facies categories (labeled A, AB, B, BC, C, CD, and D; Jones, 1987) are also shown in figure 25 . HI values of organic matter in coals range from 130 to $350 \mathrm{mg} / \mathrm{g}$; for the coal-associated mudstone shale and mudstone samples, the values range from 45 to $410 \mathrm{mg} / \mathrm{g}$. $\mathrm{HI}$ values for most coal samples (33 of 40) and shale and mudstone samples (33 of 48) are between 150 and $300 \mathrm{mg} / \mathrm{g}$ (organic facies $\mathrm{C}$ and $\mathrm{BC}$, fig. 25). The similar distributions of $\mathrm{HI}$ for the coals and coal-associated shales suggest a common source for most of the organic matter (Hatch and others, 1989). When thermally mature, the beds of coal and coal-associated

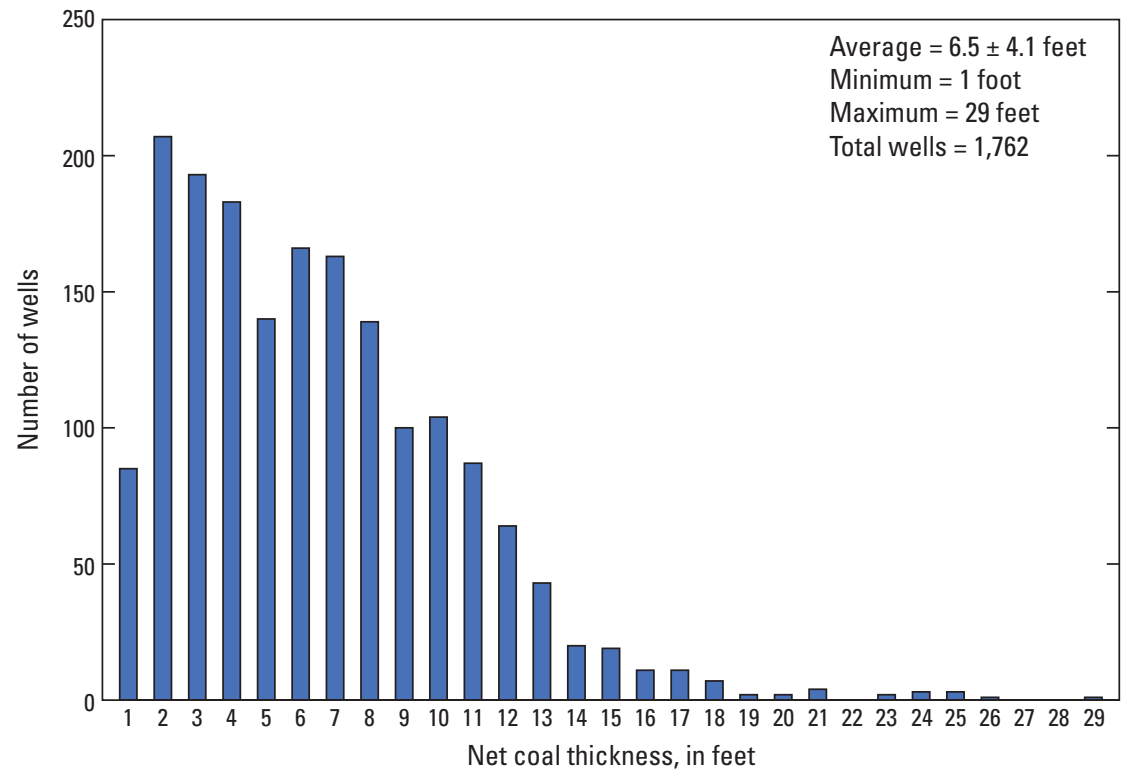

Figure 22. Distribution of net thicknesses of Cherokee Group coals in wells from the area of the Desmoinesian Coalbed Gas Assessment Unit in southeastern Kansas and northeastern Oklahoma (IHS Markit ${ }^{\mathrm{TM}}$, 2014). 


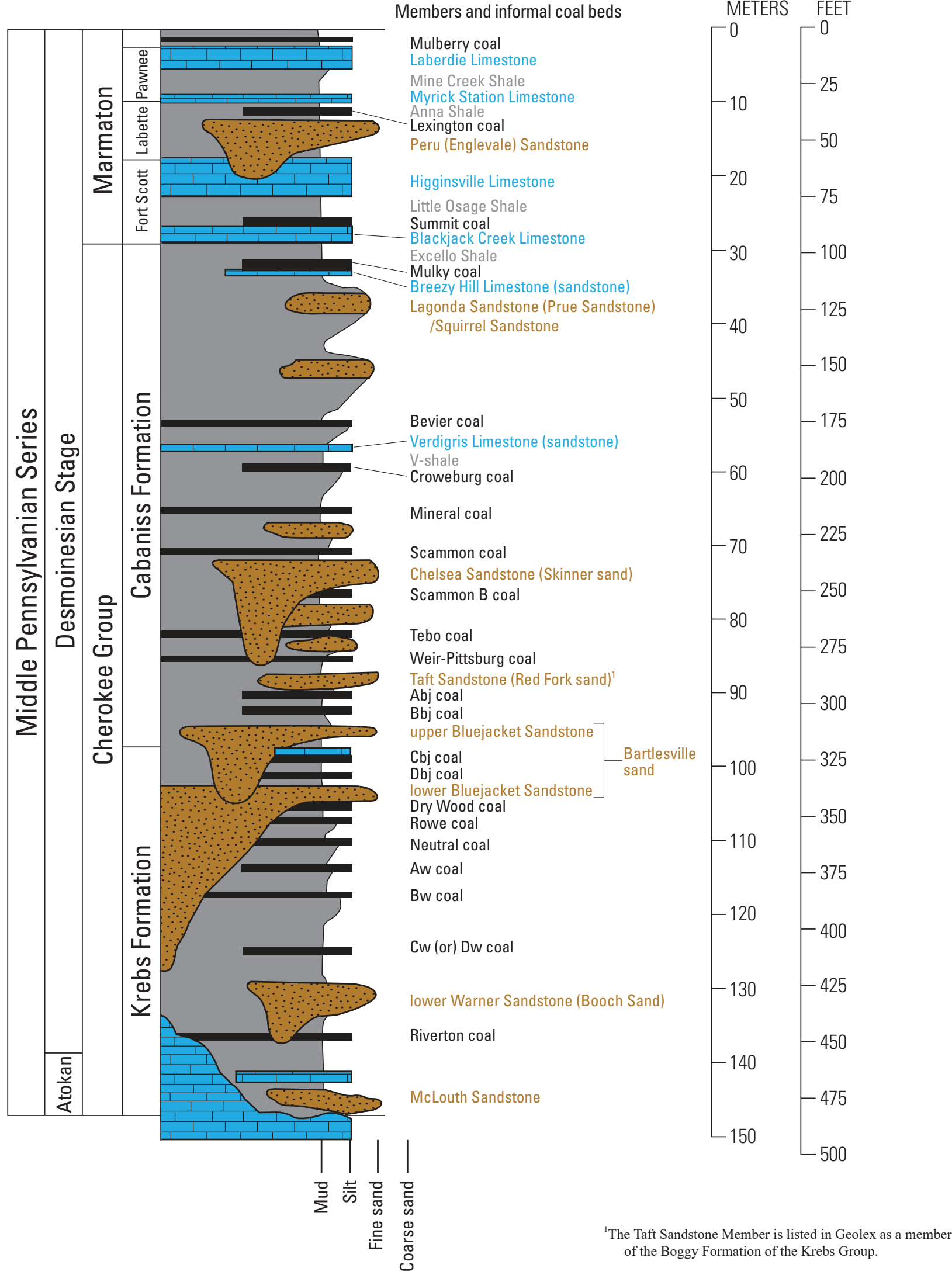

Figure 23. Desmoinesian Cherokee and Marmaton Groups in the Cherokee Platform area of southeastern Kansas and northeastern Oklahoma (modified from Hemish and Suneson, 1997; Lange and others, 2003; Newell and others, 2004) (Taft Sandstone Member is listed in Geolex as a member of the Boggy Formation of the Krebs Group). 


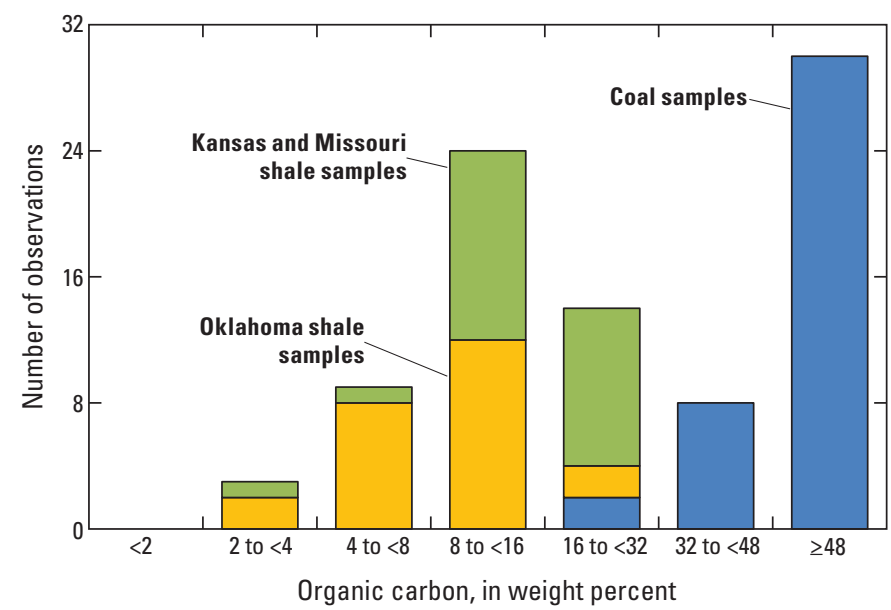

Figure 24. Distribution of organic-carbon contents for 40 coal and 48 coal-associated shale and mudstone samples from the Desmoinesian Cherokee Group and Marmaton Group of southwestern Missouri, southeastern Kansas, and northeastern Oklahoma. Data are from Hatch and others $(1984,1989)$ and unpublished U.S. Geological Survey analyses from two wells from Mclntosh and Nobel Counties, Oklahoma; Rock-Eval $\mathrm{T}_{\max }$ $\leq 450$ degrees Celsius for all samples.

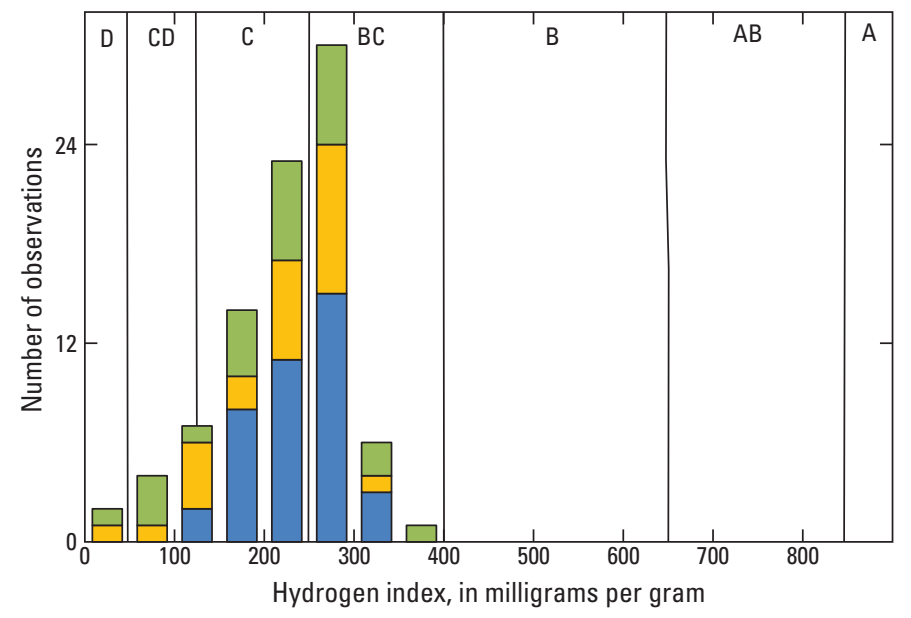

EXPLANATION

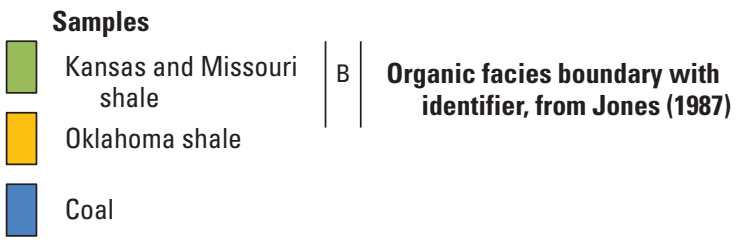

Figure 25. Distribution of hydrogen indices for $40 \mathrm{coal}$ and 48 coal-associated shale and mudstone samples from the Middle Pennsylvanian (Desmoinesian) of southeastern Kansas and northeastern Oklahoma. Data are from Hatch and others (1984, 1989) and unpublished data from two cores from McIntosh and Noble Counties, Oklahoma; $T_{\max } \leq 450$ degrees Celsius for all samples. shale and mudstone with organic facies $\mathrm{C}$ compositions should primarily generate gas and gas condensate, whereas, the beds with organic facies BC compositions have potential to generate both gas and oil.

\section{Organic Matter Thermal Maturity}

The distributions of $\mathrm{T}_{\max }$ values for 27 coal samples from southeastern Kansas and southwestern Missouri and 29 coal samples from northeastern Oklahoma are shown in figure 26. Locations of $\mathrm{R}_{\mathrm{o}}$ lines were estimated from the best fit line for the $\mathrm{R}_{\mathrm{o}}$ data in Hatch and others (1984). Median $\mathrm{T}_{\max }$ measure for the southeastern Kansas and southwestern Missouri coals is $439{ }^{\circ} \mathrm{C}$; range is from 432 to $453{ }^{\circ} \mathrm{C}$. For the Oklahoma coals, median $\mathrm{T}_{\max }$ is $452{ }^{\circ} \mathrm{C}$, range is from 429 to $470{ }^{\circ} \mathrm{C}$. For Kansas coals, the highest $\mathrm{T}_{\text {max }}$ measures are on the eastern edge of the province in Cherokee County $\left(\mathrm{T}_{\max }\right.$ ranges from 438 to $450^{\circ} \mathrm{C}$ ) and on the western edge in Greenwood County, $\left(\mathrm{T}_{\max }\right.$ ranges from 438 to $445^{\circ} \mathrm{C}$ ). For Oklahoma, the highest $\mathrm{T}_{\max }$ measures are in Osage County $\left(\mathrm{T}_{\max }\right.$ ranges from 454 to $\left.470{ }^{\circ} \mathrm{C}\right) . \mathrm{T}_{\max }$ measures are also higher on the eastern edge of the province in Craig and Rogers Counties, Oklahoma $\left(\mathrm{T}_{\max }\right.$ ranges from 439 to $454^{\circ} \mathrm{C}$ ) (Hatch and others, 1984, 1989; Barker and others, 1992; Newell and others, 2004).

Figure 27 shows a cross plot of $\mathrm{HI}$ and $\mathrm{T}_{\max }$ for 27 coal samples from southeastern Kansas and southwestern Missouri and 29 coal samples from northeastern Oklahoma. Figure 28 shows a cross plot of $\mathrm{HI}$ and $\mathrm{T}_{\max }$ for 27 shale and mudstone samples from southeastern Kansas and southwestern Missouri and 45 shale and mudstone samples from northeastern Oklahoma (Hatch and others 1984, 1989; Barker and others, 1992). Both plots show general decreases in the highest $\mathrm{HI}$ values between $\mathrm{T}_{\max }$ measures of about 430 to near $450{ }^{\circ} \mathrm{C}$ ( $\mathrm{R}_{\mathrm{o}}<0.50$ to about 0.75 percent). For coal, the highest HI values decrease from 340 to $350 \mathrm{mg} / \mathrm{g}$ to 280 to $290 \mathrm{mg} / \mathrm{g}$; for shales, the decreases in HI are from 330 to 340 to 280 to $290 \mathrm{mg} / \mathrm{g}$. These decreases likely represent the generation of early thermogenic gas and gas condensate. At $\mathrm{T}_{\max }$ measures near $450{ }^{\circ} \mathrm{C}\left(\mathrm{R}_{\mathrm{o}}=0.75\right.$ percent $)$, the highest hydrogen index values for the coals drop from 280 to $290 \mathrm{mg} / \mathrm{g}$ to near $240 \mathrm{mg} / \mathrm{g}$; for shales, the drop in HI values are from 280 to $290 \mathrm{mg} / \mathrm{g}$ to near $170 \mathrm{mg} / \mathrm{g}$. Assuming that the original organic matter compositions of the coals and shales and mudstones in areas in and adjacent to Osage County, Oklahoma, where $\mathrm{T}_{\text {max }}$ measures are $\geq 450^{\circ} \mathrm{C}$, were similar to compositions farther to the north in Kansas and to the east in Craig, Rogers, and McIntosh Counties, Oklahoma, the decreases in HI may indicate an increase in the rates of generation and expulsion of thermogenic gas and gas condensate.

Through modeling using paleotemperatures, reconstructed peak burial depths, and geothermal gradients, several researchers (Barker and others 1992; Förster and Merriam, 1994) conclude that organic matter thermal maturity on the Cherokee Platform is higher than expected. Barker and others (1992) and Förster and Merriam, (1994) both propose flow of heated waters to account for the higher 


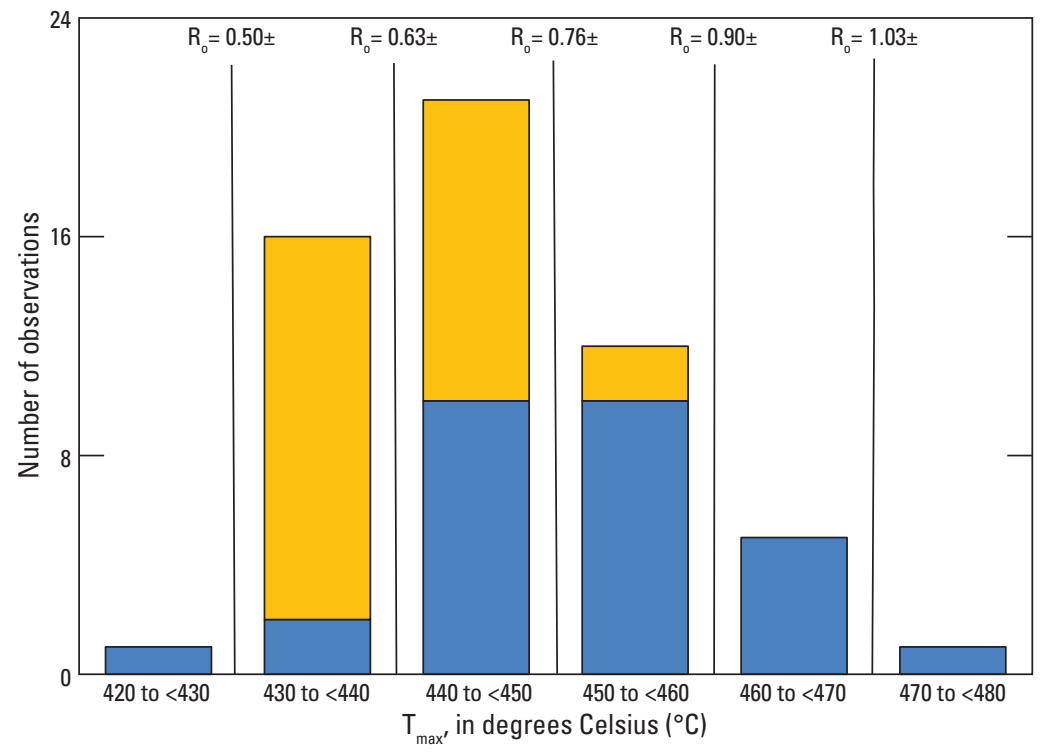

EXPLANATION

Coal samples
$\begin{aligned} & \text { Kansas and Missouri } \\ & \text { Oklahoma }\end{aligned}$
$\begin{aligned} & \text { Vitrinite Reflectance }\left(R_{0}\right) \\ & \text { line, in percent }\end{aligned}$

Figure 26. Distribution of $T_{\max }$ measures for 27 coal samples from southeastern Kansas and southwestern Missouri and 29 coal samples from northeastern Oklahoma. $\mathrm{T}_{\max }$ is the temperature at which the maximum rate of hydrocarbon generation occurs in a kerogen sample during pyrolysis. Data are from Hatch and others $(1984,1989)$. Locations of $R_{0}$ lines were estimated from the best fit line for the $R_{0}$ data in Hatch and others (1984).

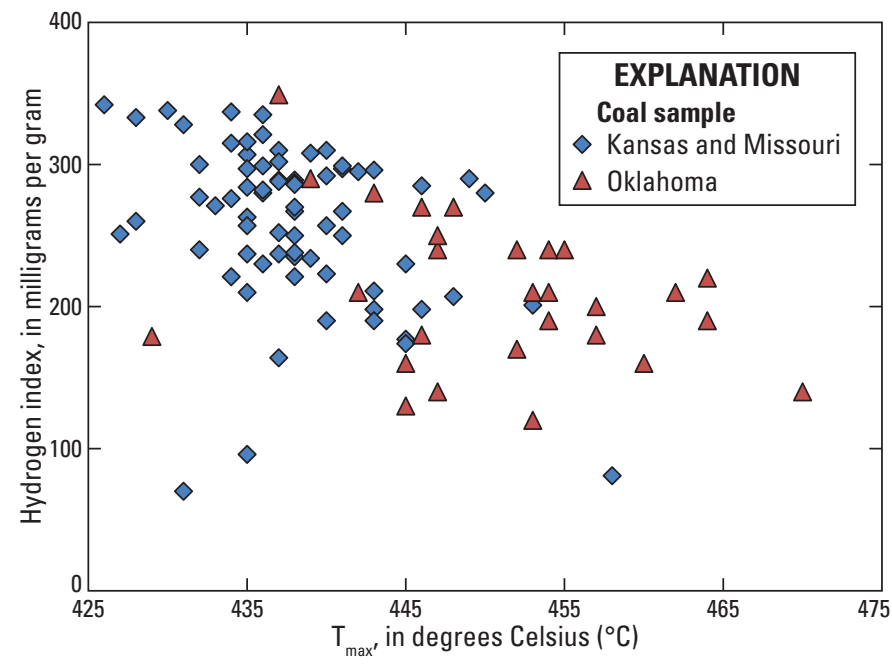

Figure 27. Relation between hydrogen index and $\mathrm{T}_{\max }$ degree Celsius for 27 coal samples from southeastern Kansas and southwestern Missouri and 29 coal samples from northeastern Oklahoma. $T_{\max }$ is the temperature at which the maximum rate of hydrocarbon generation occurs in a kerogen sample during pyrolysis. Data are from Hatch and others $(1984,1989)$ and Barker and others (1992).

than expected vitrinite reflectance measurements. Förster and Merriam (1994) invoke flow of heated waters out of the deep Anadarko and Arkoma Basins to explain the discrepancy. Direct evidence for flow of heated waters exists in the sphalerite, pyrite, and calcite mineralization found in coals

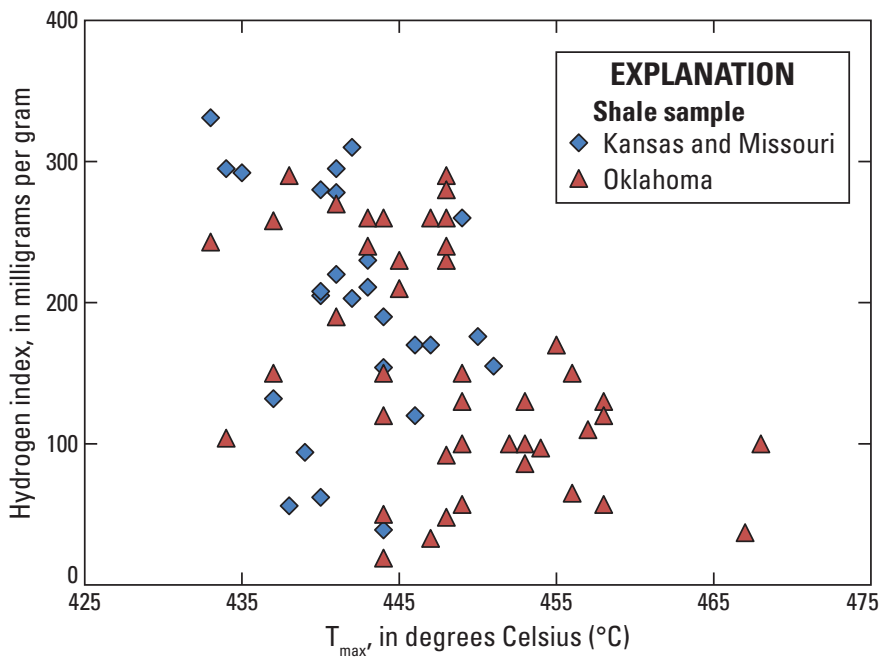

Figure 28. Relation between hydrogen index and $T_{\max }$ degree Celsius for 27 Middle Pennsylvanian shale and mudstone samples from southeastern Kansas and southwestern Missouri and 45 shale and mudstone samples from northeastern Oklahoma. $T_{\max }$ is the temperature at which the maximum rate of hydrocarbon generation occurs in a kerogen sample during pyrolysis. Data are from Hatch and others (1984, 1989) and Barker and others (1992).

from Bourbon and Crawford Counties in Kansas, and from Bates, Vernon, and Barton Counties in Missouri, and from Craig County in Oklahoma (Hatch and others, 1976; Wedge and Hatch, 1980; Brady and Hatch, 1997; Goldstein and King, 2014). 


\section{Petroleum Geochemistry}

Jenden and others (1988) used multiple parameters, isotope compositions, and cross plots to study the compositions of natural gases produced from conventional petroleum reservoirs in eastern Kansas. As shown in figure 29, their analyses demonstrate that the produced natural gases have mixed origins: natural gases from 3 reservoirs are of biogenic origin; natural gases from 11 reservoirs are of thermogenic origin; whereas, natural gases from 11 reservoirs have a mixed biogenicthermogenic origin. Newell and others (2004), building on the research of Jenden and others (1988), demonstrated that natural gases produced from coals in Montgomery and Labette Counties, Kansas, other areas on the Bourbon arch and areas from southeastern part of the Forest City Basin also have biogenic and mixed biogenic-thermogenic origins (fig. 29).

The sources of most of the thermogenic gas component of coalbed gases from southeastern Kansas, where the coals are of low relative thermal maturity, are likely to be from the conventional petroleum reservoirs found throughout the Cherokee Platform area (Newell and others, 2004). This explanation is supported by large increases in coalbed gas contents (as determined by desorption of coal cores) in cores of the Weir-Pittsburgh coal from Montgomery County, Kansas, where desorbed gas contents range up to near 250 standard cubic feet per ton compared to most other coals where gas contents of cores are near 100 standard cubic feet per ton (Lange and others, 2003; Newell and others, 2004).

Newell and others (2004) also show that biodegradation of some coalbed gases has taken place. In figure 29, gases with wetness values that are significantly lower than those of most of the mixed gases ( $<0.5$ percent $)$ are probably the result of biodegradation. This interpretation is also applicable to the gases from conventional reservoirs with similar compositions.

\section{Geologic Model for Assessment}

The geologic model for the assessment of the Desmoinesian Coal TPS and Desmoinesian Coalbed Gas $\mathrm{AU}$ is that the natural gases produced from the coals may have biogenic and(or) a mixed biogenic-thermogenic origin (fig. 29). The sources of most of the thermogenic gas component of coalbed gases are likely to be from the conventional petroleum reservoirs found throughout the Cherokee Platform area (Newell and others, 2004). Farther south, in Oklahoma, where the coals are more thermally

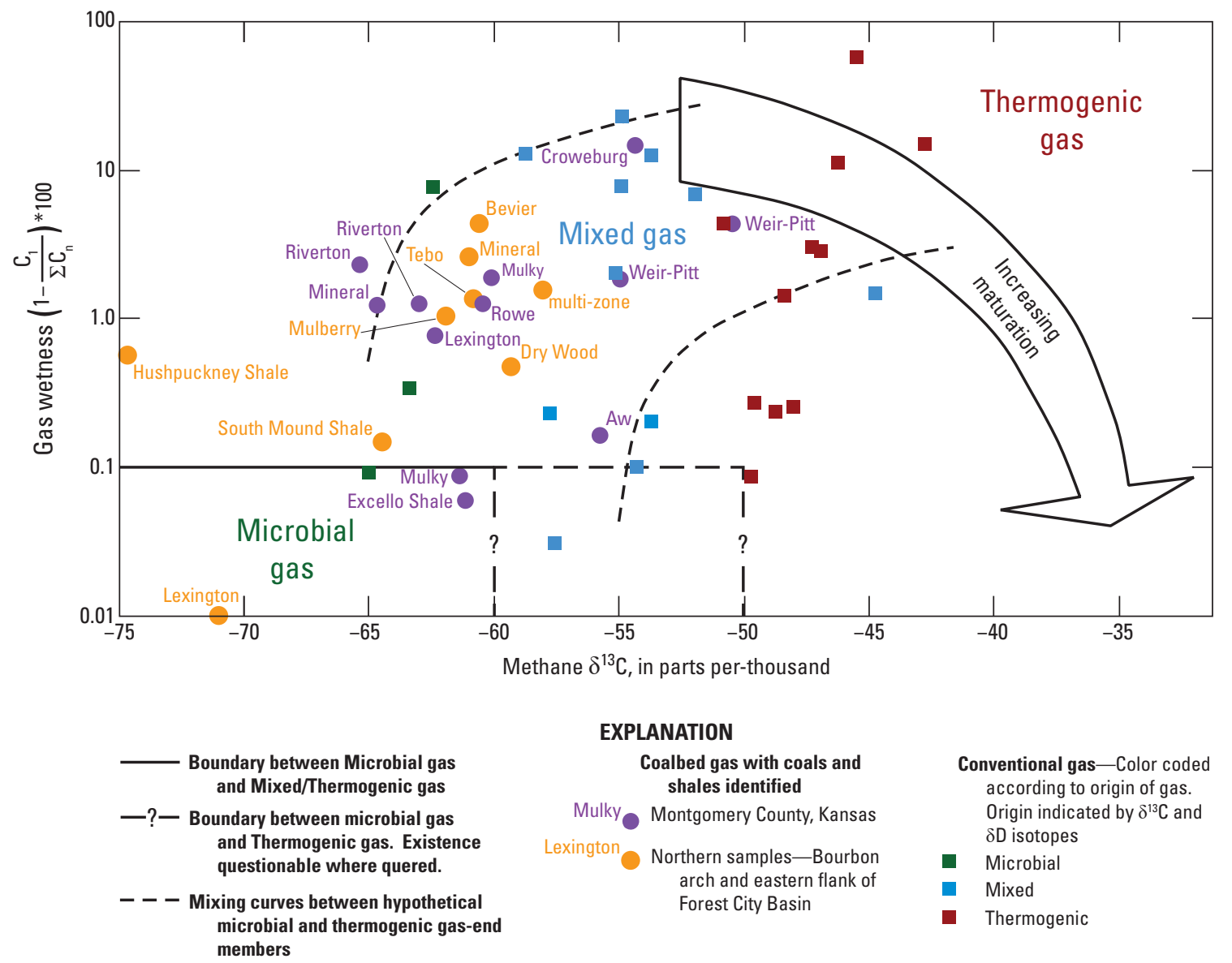

Figure 29. Gas wetness (liquid portion of C1-C5 alkanes) compared with methane $\delta^{13} \mathrm{C}$. The short-dashed lines are mixing curves between hypothetical microbial and thermogenic gas-end members (modified from Jenden and others, 1988; Newell and others, 2004) 
mature, additional amounts of thermogenic gas could have originated within the coals or from the coal-associated shales and mudstones. The coalbed gas is produced from coals at depths of 300 to 2,900 ft. Most coalbed gas production takes place where net coal thickness is about $10 \mathrm{ft}$ thick or greater (fig. 30). Production is usually from several coalbeds in a vertical well that was stimulated. When coals and organic-matter-rich shales and mudstones are in close stratigraphic proximity (for example, Mulky coal (informal) and Excello Shale, fig. 23), natural gases can be coproduced from both rock types during coalbed gas recovery (Nelson and Pratt, 2001). There is some uncertainty in this assessment with whether there was sufficient coal thickness and gas charge remaining within the coals.

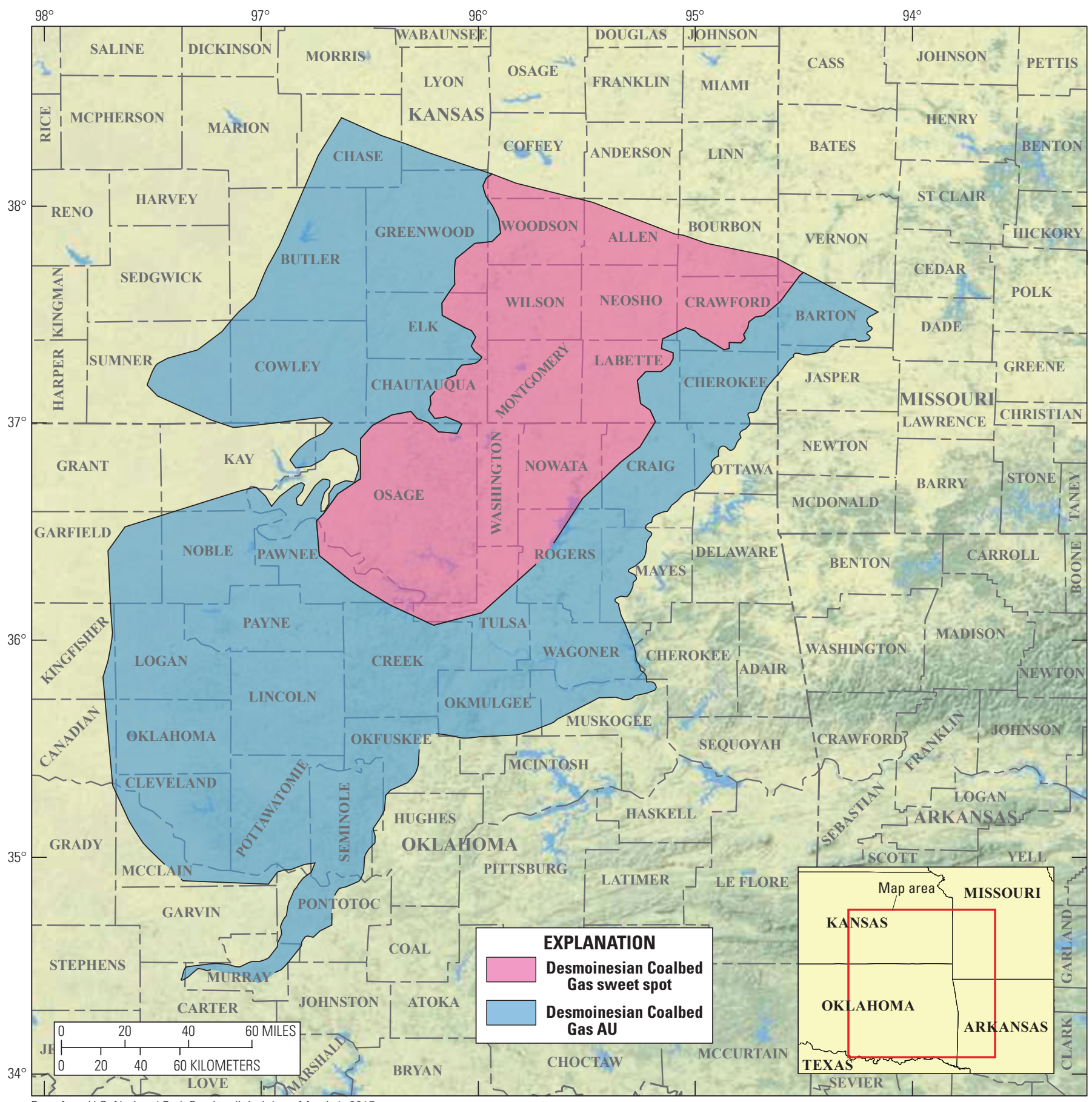

Base from U.S. National Park Service digital data, March 1, 2015

Geographic coordinate system, decimal degrees

World Geodetic System 1984 datum

Figure 30. Desmoinesian Coalbed Gas Assessment Unit (AU) and the Desmoinesian Coalbed Gas sweet spot. The sweet spot area is based on where net coal thickness is at least 10 feet. 


\section{Assessment Unit Description and Input Data}

The Desmoinesian Coalbed Gas AU (figs. 6 and 30) is bounded on the north by the Bourbon arch and on the west by Nemaha uplift and is defined by the spatial extent of the coals (IHS Markit $\left.{ }^{\mathrm{TM}}, 2014\right)$. The assessment unit is bounded on the south and the east by the outcrop and subcrop of the Middle Pennsylvanian coals (East, 2013) and on the southeast by the boundary with the Arkoma Basin. Along the west side, a net coal thickness map (Peterson and Jacobs, 1997) and borehole data (IHS Markit ${ }^{\mathrm{TM}}$, 2014) were used to add detail to the western boundary based on the presence of the coals. By using borehole data and other published data (Kansas
Geological Survey, Cherokee Group net coal thickness maps by Johnson, 2004), a net coal thickness map was created for the Cherokee Platform area in Kansas and Oklahoma. Using this map, a sweet spot map was created based on where net coal thickness is at least $10 \mathrm{ft}$ (fig. 30). This area covers most of the north-central part of the assessment unit. Input data for the assessment of the Desmoinesian Coalbed Gas AU are shown in table 9. Input data for the USGS petroleum resource assessments are described in Schenk and Nelson (2015). Assessment results for the Desmoinesian Coalbed Gas AU are shown in table 10, and assessment results for all assessed conventional and continuous petroleum resources in the Cherokee Platform Province area are summarized in table 11.

Table 9. Key assessment input data for the Desmoinesian Coalbed Gas Assessment Unit in the Cherokee Platform Province (from Drake and others, 2015).

[The input for the average estimated ultimate recovery per well is the minimum, median, maximum, and calculated mean. AU, assessment unit; EUR, estimated ultimate recovery per well; BCFG, billion cubic feet of gas; \%, percent]

\begin{tabular}{lcccc}
\hline \multicolumn{1}{c}{ Desmoinesian Coalbed Gas AU } & Minimum & Mode & Maximum & Calculated mean \\
\hline Potential production area of AU (acres) & $5,000,000$ & $5,500,000$ & $16,976,000$ & $9,158,667$ \\
Average drainage area of wells (acres) & 60 & 80 & 160 & 100 \\
Percentage of total AU area that is untested (\%) & 88 & 92 & 96 & 95 \\
Percentage of untested AU area in sweet spots (\%) & 50 & 90 & 85 & 95 \\
Success ratio (\%) in sweet spots & 75 & 0.15 & 0.6 & 78.3 \\
Average EUR (MMBO) in sweet spots & 0.06 & 10 & 20 & 0.175 \\
Success ratio (\%) in non-sweet spots & 5 & 0.1 & 0.5 \\
Average EUR (MMBO) in non-sweet spots & 0.03 & & 11.7 \\
\hline
\end{tabular}

Table 10. Assessment results for petroleum resources in the Desmoinesian Coalbed Gas Assessment Unit in the Cherokee Platform Province area (from Drake and others, 2015).

[Results shown are fully risked estimates. For gas accumulations, all liquids are included under the natural gas liquids category. F95 represents a 95 percent chance of at least the amount tabulated. Other fractiles are defined similarly. Fractiles are additive under the assumption of perfect positive correlation. Gray shading indicates not applicable. TPS, total petroleum system; AU, assessment unit; MMBO, million barrels of oil; BCFG, billion cubic feet of gas; NGL, natural gas liquids; MMBNGL, million barrels of natural gas liquids]

\begin{tabular}{|c|c|c|c|c|c|c|c|c|c|c|c|c|c|c|}
\hline \multirow{3}{*}{ TPS and AU } & \multirow{3}{*}{$\begin{array}{c}\text { AU } \\
\text { prob- } \\
\text { ability }\end{array}$} & \multirow{3}{*}{$\begin{array}{c}\text { Accu- } \\
\text { mulation } \\
\text { type }\end{array}$} & \multicolumn{12}{|c|}{ Total undiscovered resources } \\
\hline & & & \multicolumn{4}{|c|}{ Oil (MMBO) } & \multicolumn{4}{|c|}{ Gas (BCFG) } & \multicolumn{4}{|c|}{ NGL (MMBNGL) } \\
\hline & & & F95 & F50 & F5 & Mean & F95 & F50 & F50 & Mean & F95 & F50 & F5 & Mean \\
\hline Desmoinesian Coalbed Gas AU & 1.0 & Gas & & & & & 4,123 & 8,691 & 20,590 & 10,044 & 4 & 18 & 61 & 23 \\
\hline
\end{tabular}


Table 11. Assessment results for conventional and continuous petroleum resources in the Cherokee Platform Province area (from Drake and others, 2015).

[Results shown are fully risked estimates. For gas accumulations, all liquids are included under the natural gas liquids category. F95 represents a 95 percent chance of at least the amount tabulated. Other fractiles are defined similarly. Fractiles are additive under the assumption of perfect positive correlation. Gray shading indicates not applicable. TPS, total petroleum system; AU, assessment unit; MMBO, million barrels of oil; BCFG, billion cubic feet of gas; NGL, natural gas liquids; MMBNGL, million barrels of natural gas liquids]

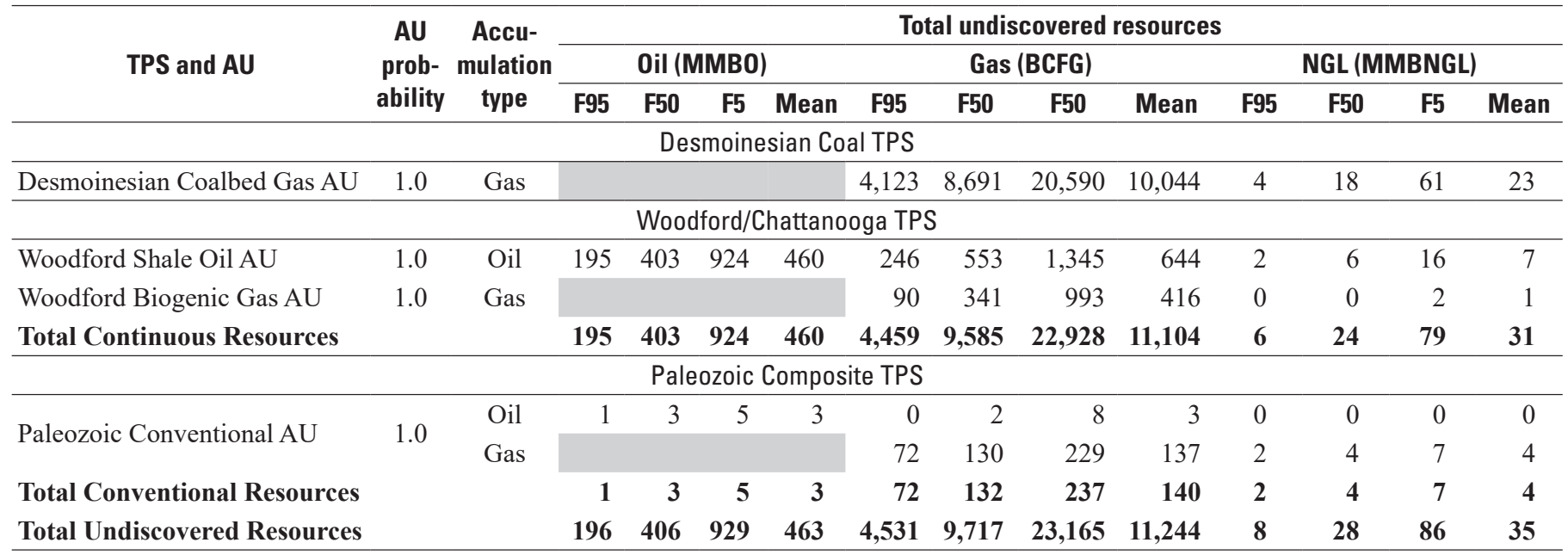

\section{Assessment Summary}

As part of a study to estimate the volumes of undiscovered, technically recoverable petroleum resources in the Cherokee Platform Province area of southeastern Kansas, northeastern Oklahoma, and southwestern Missouri, the USGS identified four stratigraphic and lithologic intervals that contained source rocks of petroleum: (1) thin shales in the Middle Ordovician Simpson Group, (2) shales within the Upper Devonian to Lower Mississippian Woodford Shale and stratigraphically equivalent Chattanooga Shale, (3) coals and coal-associated shales and mudstones in the Middle Pennsylvanian (Desmoinesian) Cherokee and Marmaton Groups, and (4) thin marine shales within the Marmaton Group and the upper Pennsylvanian (Missourian) Kansas City and Lansing Groups. Based on the characteristics of the petroleum accumulations, determinations of the petroleum source-rock potential and thermal maturity of the organic matter in the rocks, and the chemical compositions of the produced petroleum, the USGS identified three TPSs containing four AUs: the Paleozoic Composite TPS with the Paleozoic Conventional AU; the Woodford/Chattanooga TPS, with the Woodford Shale Oil AU and the Woodford Biogenic Gas AU; and the Desmoinesian Coal TPS with the Desmoinesian Coalbed Gas AU.

Assessment unit summaries follow:

1. Three petroleum source rock intervals have contributed geochemically distinct petroleum to reservoirs within the Paleozoic Conventional AU. These source rock intervals are the
Simpson Group; Woodford and Chattanooga Shales; and the Marmaton, Kansas City, and Lansing Groups. The major petroleum source rocks are the Woodford and the Chattanooga Shales. Limited mixing of petroleum has occurred. The Paleozoic Conventional AU includes reservoirs ranging from the Cambrian Arbuckle Group to the Permian Chase Group. Most oil production in the province has been from Pennsylvanian sandstone reservoirs.

2. The Woodford Shale Oil AU contains undiscovered continuous petroleum resources within the Woodford and Chattanooga Shales, and is based on the assumption that sufficient petroleum resources remain trapped within the shale following petroleum migration. For most of the area of the Woodford Shale Oil AU on the Cherokee Platform, organic matter within the Woodford and Chattanooga Shales is thermally mature with respect to petroleum generation as shown by $\mathrm{R}_{\mathrm{o}}$ measurements between 0.6 percent and 1.0 percent. In the southeast part of the Cherokee Platform area, $R_{0}$ can be as high as 3.0 percent. Petroleum has been produced from the Woodford and Chattanooga Shales at depths of about 500 feet to almost 9,000 feet.

3. The Woodford Shale Biogenic Gas AU contains undiscovered continuous petroleum resources in the east-central portion of the Cherokee 
Platform Province near the Ozark uplift where the Woodford and Chattanooga Shales are at depths of 1,250 feet or shallower. At those depths, methanogenesis, and(or) biodegradation of thermogenic natural gases can take place where the shale may be more fractured and more susceptible to groundwater penetration. Limited chemical and isotope analyses of produced natural gas from the Woodford Shale in Wagoner County, Oklahoma, indicate that the gas that is thermogenic has been subject to biodegradation.

4. The Desmoinesian Coalbed Gas AU contains undiscovered continuous petroleum resources within the Middle Pennsylvanian coals and coal-associated shales and mudstones. The boundaries for the Desmoinesian Coalbed Gas $\mathrm{AU}$ are, in part, defined by the extent, depth, and thickness of the coalbeds. Within the Desmoinesian Coalbed Gas AU, a sweet spot area was delineated based on a 10 foot or greater net coal thickness. Gas analytical data show that natural gas produced from the coals has a mixed biogenic and thermogenic origin and that there is significant migration of natural gases into the coals from adjacent conventional sandstone reservoirs.

\section{Acknowledgments}

The authors wish to thank the Kansas Geological Survey and Oklahoma Geological Surveys for sharing their expertise and offering valuable suggestions for the assessment in the Cherokee Platform Province area. We would also like to thank Debra Higley and Brian Cardott for their reviews and suggestions for this manuscript.

\section{References Cited}

Adler, F.J., Caplan, W.M., Carlson, M.P., Goebel, E.D., Henslee H.T., Hick, I.C., Larson, T.G., McCracken, M.H., Parker, M.C., Rascoe, G., Jr., Schramm, M.W., and Wells, J.S., 1971, Future petroleum provinces of the mid-continent, in Cram, I.H., ed., Future petroleum provinces of the United States-Their geology and potential: American Association of Petroleum Geologists Memoir, v. 2, p. 985-1120.

Attanasi, E.D., Mast, R.F., and Root, D.H., 1999, Oil, gas field growth projections - Wishful thinking or reality: Oil \& Gas Journal, v. 97, no. 14, p. 79-81, accessed August 28, 2017, at https://www.ogj.com/home/article/17230875/oil-gasfield-growth-projections-wishful-thinking-or-reality.

Attanasi, E.D., and Root, D.H., 1994, The enigma of oil and gas field growth: American Association of Petroleum Geologists Bulletin, v. 78, no. 3, p. 321-332, accessed August 28, 2017, at http://archives.datapages.com/data/ bulletns/1994-96/data/pg/0078/0003/0300/0321.htm.

Barker, C.E., Goldstein, R.H., Hatch, J.R., Walton, A.W., and Wojcik, K.M., 1992, Burial history and thermal maturation of Pennsylvanian rock, Cherokee Basin, southeastern Kansas, in Johnson, K.S., and Cardott, B.J., eds., Source rocks in the southern midcontinent, 1990 symposiumProceedings of a symposium held February 6-7, 1990, in Norman, Okla.: Oklahoma Geological Survey Circular 93, p. 299-310, accessed August 16, 2016, at http://ogs.ou.edu/ docs/circulars/C93.pdf.

Blakey, R., 2013, Paleogeographic maps, North American key time slices, North America $420 \mathrm{Ma}$ Silurian (Middle to Late): Colorado Plateau Geosystems, accessed August, 2016, at http://deeptimemaps.com/wp-content/ uploads/2016/05/NAM_key-420Ma_LSil.png.

Brady, L.L., and Hatch, J.R., 1997, Chemical analyses of Middle and Upper Pennsylvanian Coals from southeastern Kansas, in Current Research in Earth Sciences Bulletin 240: Kansas Geological Survey, v. 4, p. 43-57, accessed August 2016, at http:/www.kgs.ku.edu/Current/1997/ brady/index.html.

Bray, E.E., and Evans, E.D., 1961, Distribution of n-paraffins as a clue to recognition of source beds: Geochimica et Cosmochimica Acta, v. 22, no. 1, p. 2-15, accessed August 2016, at https://doi.org/10.1016/0016-7037(61)90069-2.

Burruss, R.C., and Hatch, J.R., 1989, Geochemistry of oils and hydrocarbon source rocks, greater Anadarko BasinEvidence for multiple sources of oils and long-distance oil migration, in Johnson, K.S., ed., Anadarko Basin Symposium, 1988 - Proceedings of a symposium held April 5-6, 1988, at Norman, Okla.: Oklahoma Geological Survey Circular 90, p. 53-64, accessed August 2016, at http://ogs. ou.edu/docs/circulars/C90.pdf. 
Burruss, R.C., and Hatch, J.R., 1992, Geochemistry of Pennsylvanian crude oils and source rocks in the greater Anadarko Basin, Oklahoma, Texas, Kansas, Colorado and Nebraska-An update, in Johnson, K.S., and Cardott, B.J., eds., Source rocks in the southern midcontinent, 1990 symposium - Proceedings of a symposium held February 6-7, 1990, in Norman, Okla.: Oklahoma Geological Survey Circular 93, p. 197, accessed August 2016, at http://ogs. ou.edu/docs/circulars/C93.pdf.

Cardott, B.J., 2005, Overview of unconventional energy resources of Oklahoma, in Cardott, B.J., ed., Unconventional energy resources in the southern midcontinent, 2004 symposium-Proceedings of a symposium held March 9-10, 2004, in Oklahoma City, Okla.: Oklahoma Geological Survey Circular 110, p. 7-18, accessed September 2014, at http://ogs. ou.edu/docs/circulars/C110.pdf.

Cardott, B.J., 2012a, Thermal maturity of Woodford Shale gas and oil plays, Oklahoma, USA: International Journal of Coal Geology, v. 103, p. 109-119, accessed May 31, 2017, at https://doi.org/10.1016/j.coal.2012.06.004.

Cardott, B.J., 2012b, Oklahoma Woodford Shale Oil and Gas Plays, 2012 update: Oklahoma Corporation Commission, 45 p., accessed September 2014, at http://www.ogs.ou.edu/ fossilfuels/pdf/2012OCCWoodford.pdf.

Carlson, M. and Newell, K.D., 1997, Stratigraphy and petroleum production of the Simpson and Viola (Ordovician) in Kansas and Nebraska, in Johnson, K.S., ed., Simpson and Viola Groups in the southern midcontinent, 1994 symposium - Proceedings of a symposium held March 29-30, 1994, in Norman, Okla.: Oklahoma Geological Survey Circular 99, p. 58-64. [Also available at http://ogs. ou.edu/docs/circulars/C99.pdf.]

Charpentier, R.R., and Klett, T.R., 2005, A Monte Carlo simulation method for the assessment of undiscovered, conventional oil and gas, chap. 21 in USGS Southwestern Wyoming Province Assessment Team, comps., Petroleum systems and geologic assessment of oil and gas in the southwestern Wyoming province, Wyoming, Colorado and Utah: U.S. Geological Survey Digital Data Series DDS-69-D, 5 p., accessed October 2014, at http://certmapper. cr.usgs.gov/data/noga00/natl/text/CH_21.pdf.]

Charpentier, R.R., and Cook, T.A., 2011, USGS methodology for assessing continuous petroleum resources: U.S. Geological Survey Open-File Report 2011-1167, 75 p., accessed September 2014, at http://pubs.usgs.gov/ of $/ 2011 / 1167 /$.
Comer, J.B., 1990, Organic geochemistry and paleogeography of Upper Devonian formations in Oklahoma and western Arkansas, in Johnson, K.S., and Cardott, B.J., eds., Source rocks in the southern midcontinent, 1990 symposiumProceedings of a symposium held February 6-7, 1990, in Norman, Okla.: Oklahoma Geological Survey Circular 93, p. 70-93, accessed November 24, 2014, at http://ogs.ou.edu/ docs/circulars/C93.pdf.

Comer, J.B., 2005, Facies distribution and hydrocarbon production potential of Woodford Shale in the southern midcontinent, in Cardott, B.J., ed., Unconventional energy resources in the southern midcontinent, 2004 symposiumProceedings of a symposium held March 9-10, 2004, in Oklahoma City, Okla.: Oklahoma Geological Survey Circular 110, p. 51-62.

Dolton, G.L., and Finn, T.M., 1988, Petroleum geology of the Nemaha uplift, central mid-continent: U.S. Geological Survey Open-File Report 88-450-D, 41 p., accessed September, 2014, at https://doi.org/10.3133/ofr88450D.

Drake, R.M., II, Hatch, J.R., Schenk, C.J., Charpentier, R.R., Klett, T.R., Phuong, A.L., Leathers, H.M., Brownfield, M.E., Gaswirth, S.B., Marra, K.R., Pitman, J.K., Potter, C.J., and Tennyson, M.E., 2015, Assessment of undiscovered oil and gas resources in the Cherokee Platform Province area of Kansas, Oklahoma, and Missouri, 2015: U.S. Geological Survey Fact Sheet 2015-3054, 2 p., accessed December, 2015, at https://doi.org/10.3133/fs20153054.

Drew, L.J., and Schuenemeyer, J.H., 1993, The evolution and use of discovery process models at the U.S. Geological Survey: American Association of Petroleum Geologists Bulletin, v. 77, no. 3, p. 467-478.

East, J.A., 2013, Coal fields of the conterminous United States-National coal resource assessment updated version: U.S. Geological Survey Open-File Report 2012-1205, 1 sheet, scale 1:5,000,000, accessed September 2014, at http://pubs.usgs.gov/of/2012/1205/.

Förster, A., and Merriam, D.F., 1994, Some aspects of geothermics in basin analysis-Papers and extended abstracts: International Association for Mathematical Geology Annual Conference, Mont Treblant, Québec, Canada, p. 130-140.

Förster, A., Merriam, D.F., and Hoth, P., 1998, Geohistory and thermal maturation in the Cherokee Basin (mid-continent, U.S.A.) - Results from modeling: American Association of Petroleum Geologists Bulletin, v. 82, p. 1673-1693. 
Gaswirth, S.B., and Higley, D.K., 2014, Geologic assessment of undiscovered oil and gas resources in the CambrianDevonian stratigraphy of the Anadarko Basin, Oklahoma, Kansas, Texas, and Colorado, chap. 5 in Higley, D.K., comp., Petroleum systems and assessment of undiscovered oil and gas in the Anadarko Basin Province, Colorado, Kansas, Oklahoma, and Texas-U.S. Geological Survey Province 58: U.S. Geological Survey Digital Data Series DDS-69-EE, 42 p., accessed January, 2015, at http://doi. org/10.3133/ds69EE.

Gautier, D.L., Dolton, G.L., Takahashi, K.I., and Varnes, K.L., 1995, 1995 National assessment of United States oil and gas resources-Results, methodology, and supporting data: U.S. Geological Survey Digital Data Series DDS-30, 1 CD-ROM.

Goldstein, R., and King, B., 2014, History of hydrothermal fluid flow in the midcontinent-A key to understanding the origin and distribution of porosity: American Association of Petroleum Geologists Search and Discovery, no. 50958, accessed January, 2015, at http://www.searchanddiscovery. com/pdfz/documents/2014/50958goldstein/ndx_goldstein. pdf.html.

Ham, W.E., 1973, Regional geology of the Arbuckle Mountains, Oklahoma: Oklahoma Geological Survey Special Publication 73-3, $61 \mathrm{p}$.

Hatch, J.R., Avcin, M.J., Wedge, W.K., and Brady, L.L., 1976, Sphalerite in coals from southeastern Iowa, Missouri, and southeastern Kansas: U. S. Geological Survey, Open-File Report 76-796, 27 p., accessed May 14, 2014, at https://doi. org/10.3133/ofr76796.

Hatch, J.R., Daws, T.A., Lubeck, Sister C.M., Pawlewicz, M.J., Threlkeld, C.M., and Vuletich, A.K., 1984, Organic geochemical analyses for 247 organic rich rocks and 11 oil samples from the Middle Pennsylvanian Cherokee and Marmaton Groups, southeastern Iowa, Missouri, southeastern Kansas and northeastern Oklahoma: U.S. Geological Survey Open-File Report 84-160, 41 p., accessed May 14, 2014, at https://doi.org/10.3133/ofr84160.

Hatch, J.R., Jacobson, S.R., Witzke, B.J., Risatti, J.B., Anders, D.E., Watney, W.L., Newell, K.D., and Vuletich, A.K., 1987, Possible late Middle Ordovician organic carbon isotope excursion-Evidence from Ordovician oils and hydrocarbon source rocks, mid-continent and eastcentral United States: American Association of Petroleum Geologists Bulletin, v. 71, no. 11, p. 1342-1354.

Hatch, J.R., King, J.D., and Daws, T.A., 1989, Geochemistry of Cherokee Group oils of southeastern Kansas and northeastern Oklahoma: Kansas Geological Survey Subsurface Geology Series 11, 20 p., accessed May 14, 2014, at http://www.kgs.ku.edu/Publications/Bulletins/ Sub11/sub11_cherokee.pdf.]
Hatch, J.R., and Leventhal, J.S., 1992, Relationship between inferred redox potential of the depositional environment and geochemistry of the Upper Pennsylvanian (Missourian) Stark Shale Member of the Dennis Limestone, Wabaunsee County, Kansas, U.S.A.: Chemical Geology, v. 99, no. 1-3, p. 65-82, accessed May, 2014, at https://doi. org/10.1016/0009-2541(92)90031-Y.

Hatch, J.R., and Newell, K.D., 1999, Geochemistry of oils and hydrocarbon source rocks from the Forest City Basin, northeastern Kansas, northwestern Missouri, southwestern Iowa and southeastern Nebraska: Kansas Geological Survey Technical Series 13, 32 p., accessed May 20, 2014, at http:// www.kgs.ku.edu/Publications/Bulletins/TS13/ts13.pdf.

Hamak, J.E., and Sigler, S., 1991, Analyses of natural gases, 1986-90: U.S. Bureau of Mines Information Circular 9301, $315 \mathrm{p}$.

Heckel, P.H., 1977, Origin of phosphatic black shale facies in Pennsylvanian cyclothems of mid-continent North America: American Association of Petroleum Geologists Bulletin, v. 61 , no. 7, p. 1045-1068, accessed June 2014, at http:// archives.datapages.com/data/bulletns/1977-79/images/ pg/00610007/1000/10450.pdf.

Heckel, P.H., 1986, Sea-level curve for Pennsylvanian eustatic marine transgressive-regressive depositional cycles along midcontinent outcrop belt, North America. Geology, v. 14, no. 4, p. 330-334, accessed June 2014, at https://doi. org/10.1130/0091-7613(1986)14\%3C330:SCFPEM\%3E2. $0 . \mathrm{CO} ; 2$.

Heckel, P.H., 1991, Thin, widespread Pennsylvanian black shales of midcontinent North America-A record of a cyclic succession of widespread pycnoclines in a fluctuating epeiric sea, in Tyson, R.V., and Pearson, T.H., eds., Modern and ancient continental shelf anoxia: London Geological Society Special Publication, v. 58, p. 259-273, accessed June 2014, at https://doi.org/10.1144/GSL. SP.1991.058.01.17.

Hemish, L.A., and Suneson, N.H., 1997, Stratigraphy and resources of the Krebs Group (Desmoinesian), south-central Arkoma Basin, Oklahoma: Oklahoma Geological Survey Guidebook, v. 30, 83 p., accessed August 11, 2014, at http:// www.ogs.ou.edu/pubsscanned/guidebooks/GB_30.pdf.

Higley, D.K., Cook, T.A., and Pawlewicz, M.J., 2014, Petroleum systems and assessment of undiscovered oil and gas in the Anadarko Basin Province, Colorado, Kansas, Oklahoma, and Texas-Woodford Shale Assessment Units, chap. 6 in Higley, D.K., comp., Petroleum systems and assessment of undiscovered oil and gas in the Anadarko Basin Province, Colorado, Kansas, Oklahoma, and TexasUSGS Province 58: U.S. Geological Survey Digital Data Series DDS-69-EE, 24 p., accessed May 31, 2016, at http:// doi.org/10.3133/ds69EE. 
Houghton, J.C., Dolton, G.L., Mast, R.F., Masters, C.D., and Root, D.H., 1993, U.S. Geological Survey estimation procedure for accumulation size distributions by play: American Association of Petroleum Geologists Bulletin, v. 77, no. 3, p. 454-466, accessed August 11, 2014, at http:// archives.datapages.com/data/bulletns/1992-93/images/ pg/00770003/0450/04540.pdf.

Houseknecht, D.W., Coleman, J.L., Milici, R.C., Garrity, C.P., Rouse, W.A., Fulk, B.R., Paxton, S.T., Abbott, M.M., Mars, J.C., Cook, T.A., Schenk, C.J., Charpentier, R.R., Klett, T.R., Pollastro, R.M., and Ellis, G.S., 2010, Assessment of undiscovered natural gas resources of the Arkoma Basin Province and geologically related areas: U.S. Geological Survey Fact Sheet 2010-3043, 4 p., accessed July 8, 2014, at https://doi.org/10.3133/fs20103043.

IHS Markit ${ }^{\mathrm{TM}}$, 2014, US well history and production database: Englewood, CO, IHS Markit ${ }^{\mathrm{TM}}$, accessed December 16, 2014, at http://www.ihsenergy.com. [Available from IHS Markit ${ }^{\mathrm{TM}}, 15$ Inverness Way East, Englewood, CO 80112.]

IHS Markit ${ }^{\mathrm{TM}}$, 2017, US well history and production database: Englewood, CO, IHS Markit ${ }^{\mathrm{TM}}$, accessed March 31, 2017, at http://www.ihsenergy.com. [Available from IHS Markit ${ }^{\mathrm{TM}}, 15$ Inverness Way East, Englewood, CO 80112.]

Jenden, P.D., Newell, K.D., Kaplan, I. R., and Watney, W.L., 1988, Composition and stable-isotope geochemistry of natural gases from Kansas, midcontinent, U.S.A.: Chemical Geology, v. 71, no. 1-3, p. 117-147, accessed June 18, 2014, at https://doi.org/10.1016/0009-2541(88)90110-6.

Johnson, K.S., comp., 2008, Geologic history of Oklahoma: Oklahoma Geological Survey Educational Publication, v. 9, p. 3-5, accessed September 1, 2015, at http://ogs.ou.edu/ docs/educationalpublications/EP9.pdf.

Johnson, T.A., 2004, Isopach mapping of Desmoinesian coals - Bourbon arch region, eastern Kansas: Kansas Geological Survey Open File Report 2004-39, accessed June 18, 2014, at http://www.kgs.ku.edu/PRS/ publication/2004/OFR04_39/index.html.

Jones, R.W., 1987, Organic facies, in Brooks, J., and Welte, D., eds., Advances in petroleum geochemistry, volume 2: London, Academic Press, p. 1-90.

Kaufman, G., 1993, Statistical issues in the assessment of undiscovered oil and gas resources: The Energy Journal, v. 14 , p. $183-215$.

Klett, T. R., Charpentier, R.R., and Schmoker, J.W., 2000, Assessment operational procedures, chap. OP in USGS World Energy Assessment Team, eds., U.S. Geological Survey world petroleum assessment 2000_-Description and results: U.S. Geological Survey Digital Data Series DDS-60, 4 CD-ROMs, 13 p., accessed March 9, 2015, at https://doi.org/10.3133/ds60.
Kontorovich, A.E., Dyomin, V.I., and Livshits, V.R., 2001, Size distribution and dynamics of oil and gas field discoveries in petroleum basins: American Association of Petroleum Geologists Bulletin, v. 85, no. 9, p. 1609-1622, accessed December 10, 2015, at https://doi.org/10.1306/8626CCD5173B-11D7-8645000102C1865D.

Kuykendall, M.D., and Fritz, R.D., 2001, Misener sandstone of Oklahoma: American Association of Petroleum Geologists Search and Discovery Article \#10018, 74 p., accessed December 10, 2015, at http:/www.searchanddiscovery.com/ pdfz/documents/misener/images/misener.pdf.html.

La Pointe, P.R., 1995, Estimation of undiscovered hydrocarbon potential through fractal geometry, chap. 3 in Barton, C.C., and La Pointe, P.R., eds., Fractals in petroleum geology and Earth processes: New York, Plenum Press, p. 35-57, accessed October 16, 2014, at https://link.springer.com/ book/10.1007/978-1-4615-1815-0.

Lambert, M.W., 1992, Internal stratigraphy of the Chattanooga Shale in Kansas and Oklahoma, in Johnson, K.S., and Cardott, B.J., eds., source rocks in the southern midcontinent, 1990 symposium Oklahoma Geological Survey Circular 93, p. 74-105, accessed August 12, 2014, at https://www.researchgate.net/publication/307970644_ Source_rocks_in_the_southern_Midcontinent_1990_ symposium.

Lange, J.P., Carr, T.R., and Newell, K.D., 2003, Stratigraphy, depositional environments and coalbed methane resources of Cherokee Group coals (Middle Pennsylvanian) southeastern Kansas: Kansas Geological Survey Open-File Report 2003-28, accessed August 12, 2014, at http://www. kgs.ku.edu/PRS/publication/2003/ofr2003-28/index.html.

Longman, M.W., and Palmer, S.E., 1987, Organic geochemistry of mid-continent Middle and Late Ordovician oils: American Association of Petroleum Geologists Bulletin, v. 71, no. 8, p. 938-950.

Magoon, L.B., and Dow, W.G., 1994, The petroleum system, in Magoon, L.B., and Dow, W.G., eds., The petroleum system-From source to trap: American Association of Petroleum Geologists Memoir, v. 60, p. 3-24.

Meisner, J., and Demirmen, F., 1981, The creaming method-A Bayesian procedure to forecast future oil and gas discoveries in mature exploration provinces: Journal of the Royal Statistical Society, Series A, v. 144, no. 1, p. 1-31, accessed May 5, 2014 at https://doi.org/ 10.2307/2982158.

Merriam, D.F., 1963, The geologic history of Kansas: Kansas Geological Survey Bulletin 162, 317 p., accessed May 5, 2014 at http://www.kgs.ku.edu/Publications/Bulletins/162/ index.html. 
Merriam, D.F., 1999, Geologic events affecting geothermal conditions in the Cherokee Basin, southeastern Kansasreview and assessment: Transactions of the Kansas Academy of Science, v. 102, no. 3/4, p. 71-82, accessed May 5, 2014, at https://doi.org/10.2307/3627868.

Moore, B.J., and Sigler, S., 1987, Analyses of natural gases, 1917-1985: U.S. Bureau of Mines Information Circular 9129, 1,197 p., accessed August 19, 2014, at https://catalog. hathitrust.org/Record/100129625.

Moore, R.C., and Elledge, E.R., 1920, Oil and gas resources of Kansas-Part 5, Allen and Neosho counties: Kansas Geological Survey Bulletin 6, 22 p., accessed August 19, 2014, at http://www.kgs.ku.edu/Publications/Bulletins/6_5/ Bull6_5.pdf.

Moore, R.C., 1931, Pennsylvanian cycles in the northern midcontinent region, in Illinois State Geological Survey, comp., Papers presented at the quarter centennial celebration of the Illinois State Geological Survey: Illinois State Geological Survey Bulletin 60, p. 247-257, accessed August 19, 2014, at https://www.ideals.illinois.edu/handle/2142/45018.

Moore, R.C., 1935, Stratigraphic classification of the Pennsylvanian rocks of Kansas: Kansas Geological Survey Bulletin 22, v. 36, no. 22, 256 p., accessed August 19, 2014, at http://www.kgs.ku.edu/Publications/Bulletins/22/ index.html.

Nehring Associates, Inc., 2014, The significant oil and gas fields of the United States: Database available from Nehring Associates, Inc., P.O. Box 1655, Colorado Springs, CO 80901.

Nelson, C.R., and T.J. Pratt, 2001, Coalbed gas plays, reservoir variables key to success: American Oil and Gas Reporter, v. 44 , no. 3 , p. $78-87$.

Newell, K.D., 1997, Comparison of maturation data and fluidinclusion homogenization temperatures to simple thermal models - Implications for thermal history and fluid flow in the mid-continent: Kansas Geological Survey Bulletin 240, p. 13-27, accessed August 19, 2014, at https://journals. $\mathrm{ku}$. edu/mg/issue/view/1451.

Newell, K.D, and Hatch, J.R., 2000a, A petroleum system for the Salina Basin in Kansas based on organic geochemistry and geologic analog: Natural Resources Research, v. 9, no. 3, p. 169-200, accessed August 19, 2014, at https://link. springer.com/article/10.1023/A:1010151614263.

Newell, K.D, and Hatch, J.R., 2000b, Compilation of hydrocarbon source-rock analyses for wells in east-central and northeastern Kansas, and adjacent areas in Missouri and Nebraska: Kansas Geological Survey, Open-File Report 2000-64, 23 p.
Newell, K.D., and Hatch J.R., 2001, Exploration strategy for the Salina Basin, Kansas based on organic geochemical data and maturation modeling, in Johnson, K.S., and Merriam, D.F., eds., Petroleum systems of basins in the southern midcontinent, 2000 symposium: Oklahoma Geological Survey Circular 106, p. 111-120, accessed May 5, 2014, at http://ogs.ou.edu/docs/circulars/C106.pdf.

Newell, K.D., Johnson, T.A., Brown, W.M., Lange, J.P., and Carr, T.R., 2004, Geological and geochemical factors influencing the emerging coalbed gas play in the Cherokee and Forest City Basins in eastern Kansas: Kansas Geological Survey Open-File Report 2004-17, accessed May 5, 2014, at http://www.kgs.ku.edu/PRS/ publication/2004/AAPG/Coalbed/index.html.

Newell, K.D., Watney, W.L., Stephens, B.P. and Hatch, J.R., 1987, Hydrocarbon potential in the Forest City Basin: Oil and Gas Journal, v. 85 , no. 42 , p. 58-62.

Northcutt, R.A., and Johnson, K.S., 1997, Major Simpson and Viola oil and gas reservoirs in Oklahoma, in Johnson, K.S., ed., Simpson and Viola Groups in the southern midcontinent, 1994 symposium: Oklahoma Geological Survey Circular 99, p. 48-57, accessed August 19, 2014, at http://ogs.ou.edu/docs/circulars/C99.pdf.

Perry, W.J., Jr., 1989, Tectonic evolution of the Anadarko Basin region, Oklahoma: U.S. Geological Survey Bulletin 1866-A, 19 p. [Also available at https://pubs.usgs.gov/ bul/1866a/report.pdf.]

Peterson, K., and Jacobs, L.M., 1997, Coalbed methane, a viable resource-Osage mineral estate: Oklahoma City Geological Society Shale Shaker, v. 48, no. 3, p. 67-78, accessed July 8, 2014, at http://archives.datapages.com/ data/ocgs/data/048/048003/0067.htm.

Rascoe, B., Jr., and Adler, F.J., 1983, Permo-Carboniferous hydrocarbon accumulations, midcontinent, U.S.A.: American Association of Petroleum Geologists Bulletin, v. 67 , no. 6, p. 979-1001, accessed September 3, 2014, at http://archives.datapages.com/data/bulletns/1982-83/data/ pg/0067/0006/0950/0979.htm.

Ronov, A.B., 1958, Organic carbon in sedimentary rocks (in relation to the presence of petroleum), [translation]: Geochemistry, v. 5, p. 510-536.

Root, D.H., and Attanasi, E.D., 1993, A primer in fieldgrowth estimation, in Howell, D.G., ed., The future of energy gases: U.S. Geological Survey Professional Paper 1570, p. 547-554, accessed May 20, 2014, at https://doi. org/10.3133/pp1570.

Root, D.H., and Mast, R.F., 1993, Future growth of known oil and gas fields: American Association of Petroleum Geologists Bulletin, v. 77, no. 3, p. 479-484, accessed May 20, 2014, at http://archives.datapages.com/data/ bulletns/1992-93/data/pg/0077/0003/0450/0479.htm. 
Schenk, C.J., and Nelson, P.H., 2015, Geologic model and assessment of potential unconventional (tight) gas resources in Upper Cook Inlet Basin, south-central Alaska, chap. 1 in Schenk, C.J., comp., Assessment of unconventional (tight) gas resources in Upper Cook Inlet Basin, south-central Alaska: U.S. Geological Survey Digital Data Series 69-AA, 31 p., accessed October 2, 2014, at http://doi.org/10.3133/ds69AA.

Schmoker, J.W., 2005, U.S. Geological Survey assessment concepts for continuous petroleum accumulations, chap. 13 in USGS Southwestern Wyoming Province Assessment Team, National assessment of oil and gas projectPetroleum systems and geologic assessment of oil and gas in the southwestern Wyoming Province, Wyoming, Colorado, and Utah: U.S. Geological Survey Digital Data Series DDS-69-D, 7 p., accessed October 2, 2014, at https://pubs.usgs.gov/dds/dds-069/dds-069-d/reports.html.

Schmoker, J.W., and Klett, T.R., 2005, U.S. Geological Survey assessment concepts for conventional petroleum accumulations, chap. 19 in USGS Southwestern Wyoming Province Assessment Team, National assessment of oil and gas project—Petroleum systems and geologic assessment of oil and gas in the southwestern Wyoming Province, Wyoming, Colorado, and Utah: U.S. Geological Survey Digital Data Series DDS-69-D, 6 p., accessed October 2, 2014, at https://pubs.usgs.gov/dds/dds-069/dds-069-d/ reports.html.

Schuenemeyer, J.H., and Drew, L.J., 1983, A procedure to estimate the parent population of the size of oil and gas fields as revealed by a study of economic truncation: Mathematical Geology, v. 15, no. 1, p. 145-161, accessed November 12, 2015, at https://link.springer.com/ article/10.1007/BF01030080.

Schuenemeyer, J.H., and Drew, L.J., 1993, How to adjust a discovery rate forecast for field growth: 25th Anniversary Meeting of the International Association for Mathematical Geology, Prague, Czech Republic, October 10-15, 1993.

Suhm, R.W., 1997, Simpson stratigraphy of the southern midcontinent, in Johnson, K.S., ed., Simpson and Viola Groups in the southern midcontinent, 1994 symposiumProceedings of a symposium held March 29-30, 1994, in Norman, Okla.: Oklahoma Geological Survey Circular 99, p. 3-38.

U.S. Geological Survey National Oil and Gas Resource Assessment Team, 1995, 1995 National assessment of United States oil and gas resources: U.S. Geological Survey Circular 1118, 20 p., accessed May 12, 2015, at http://pubs. usgs.gov/circ/1995/circ1118/circ1118.pdf.
Wanless, H.R., and Weller, J.M., 1932, Correlation and extent of Pennsylvanian cyclothems: Geological Society of America Bulletin, v. 43, no. 4, p. 1003-1016, accessed March 9, 2015, at https://doi.org/10.1130/GSAB-43-1003.

Wedge, W.K., and Hatch, J.R., 1980, Chemical composition of Missouri coals: Missouri Department of Natural Resources Report of Investigations, no. 63, 102 p., accessed June 11, 2014, at https://share.mo.gov/nr/mgs/MGSData/ Books/Reports\%20of\%20Investigations/Chemical $\% 20$ Composition\%20of\%20Missouri\%20Coals/RI-063.pdf.

Weller, J.M., 1930, Cyclical sedimentation of the Pennsylvanian period and its significance: The Journal of Geology, v. 38, no. 2, p. 97-135.

Publishing support provided by the Science Publishing Network, Denver Publishing Service Center

For more information concerning the research in this report, contact the Center Director, USGS Central Energy Resources Science Center Box 25046, Mail Stop 939

Denver, CO 80225

303-236-1647

Or visit the Central Energy Resources Science Center website at https://www.usgs.gov/centers/cersc 


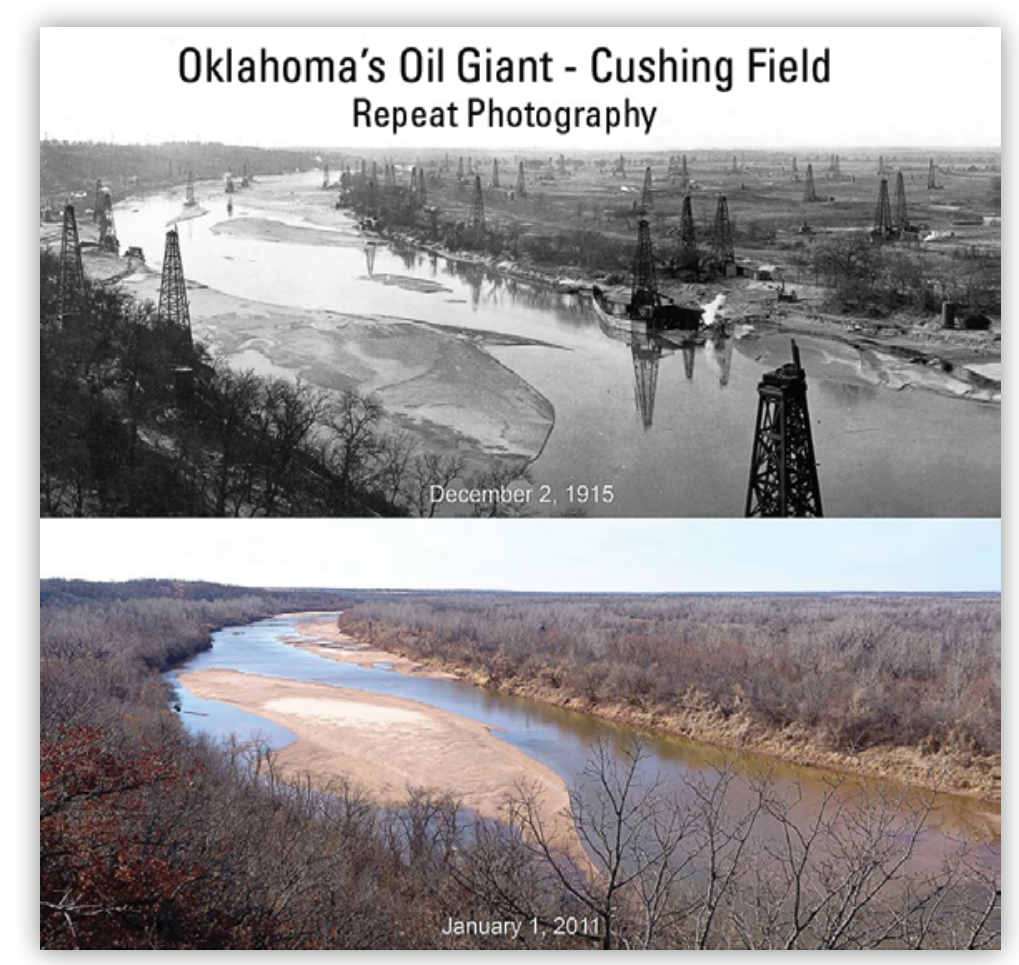

